University of Massachusetts Amherst

ScholarWorks@UMass Amherst

Masters Theses 1911 - February 2014

1937

\title{
The determination of lactic acid
}

George Raymond Pease

University of Massachusetts Amherst

Follow this and additional works at: https://scholarworks.umass.edu/theses

Pease, George Raymond, "The determination of lactic acid" (1937). Masters Theses 1911 - February 2014. 1866.

Retrieved from https://scholarworks.umass.edu/theses/1866

This thesis is brought to you for free and open access by ScholarWorks@UMass Amherst. It has been accepted for inclusion in Masters Theses 1911 - February 2014 by an authorized administrator of ScholarWorks@UMass Amherst. For more information, please contact scholarworks@library.umass.edu. 


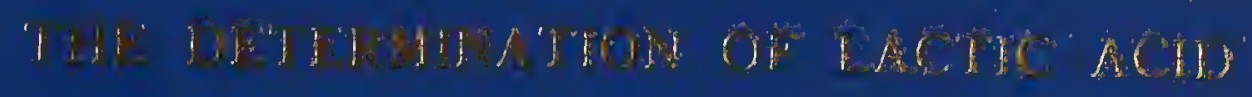

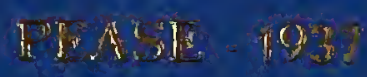

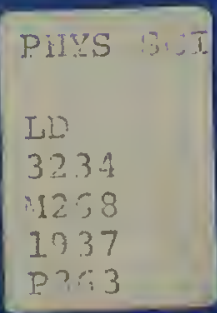



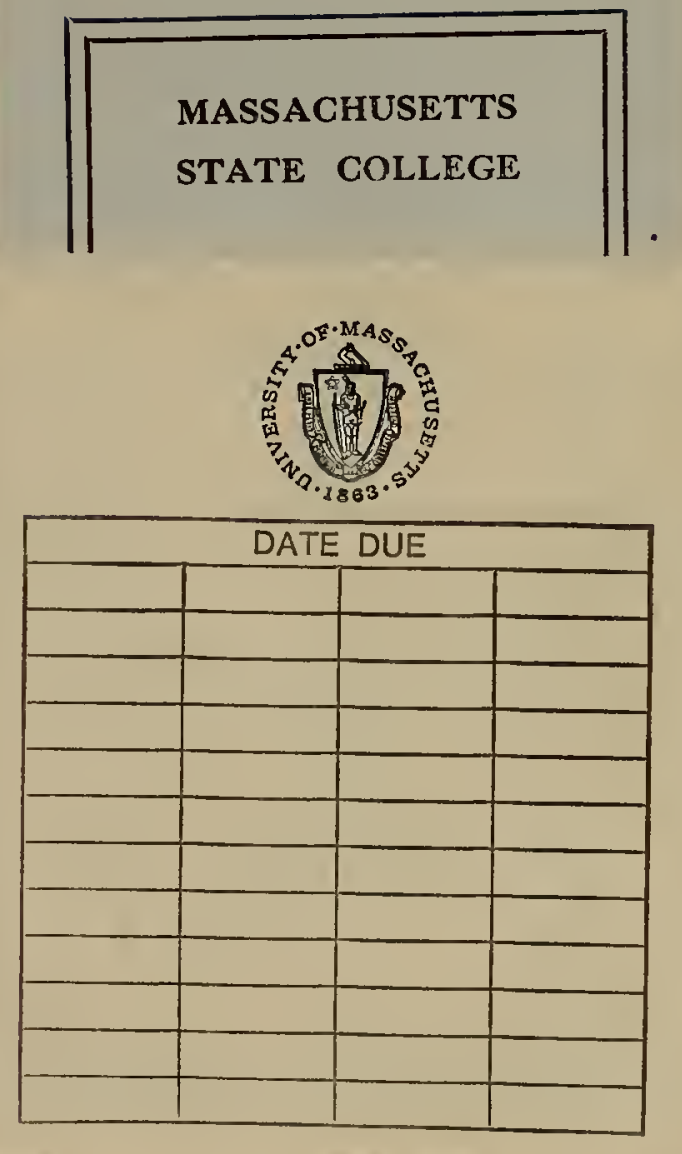

UNIVERSITY OF MASSACHUSETTS

LIBRARY
ㅁIYS SCI 


\section{THE DETERUINATION OF IACTIC ACID}

George R. Pease

Thesis submitted for

the degrae of

Master of Science

Hassachusetts State College

June, 1937 
S. Mistorion?

33. Procont Irvoutigat:or

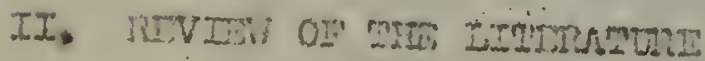

A. hotilouis of AnuIJsin Involvint tho Inolation

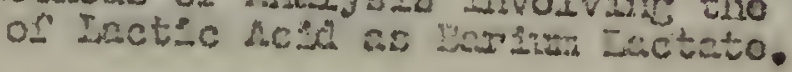

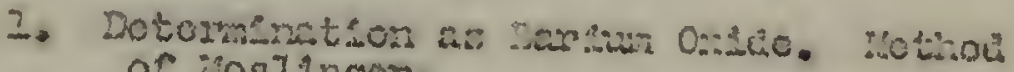
of :onI1ngor.

2. Dotomination as Dasium Sulfato. Hothod of rivis.

(a) $2.0 . \therefore . C$. Sothing.

ت. Stop matratich.

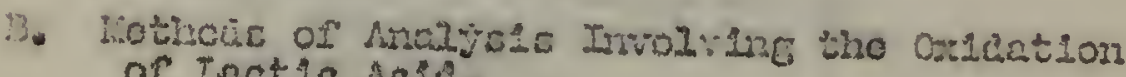
of Lact $2 \mathrm{c}$ Mcja.

1. Oxdation to Acotallohyulo, Carbón Lonozido cand Wator. Tho Clauson inotiod.

2. Oxidation to AcotaIdehyto, Caibon Dlosido and Wator by Potesalum. Pormaricenato and liancanose Dioxido in Acic Colution.

(a) Aboorption of Acotaldohyle in Iodin Solution. Tho Doas Lothod.

(b) Absorption of Acotaldohyco in B1eulfito. "iothols of von Niorth ot al. and Fiodoram ot a..

(c) Aotorption of Acotaldohycio in islvor Iintrato.

(a) Abaoxntion of Acotaldehydo in Iydroxyarrine.

3. Oxidritur to Oxalic scli by Iotrastur

scruancanato in Ajiminno solution

4. Cxilation to $\Lambda \cot 1 \mathrm{c} \Lambda \mathrm{Cld}$ by Dicimonnto 
C. Oasornotrio Nothora

1. Coloritrotric Lothods 84

15. Miscolianoous Mothous 25

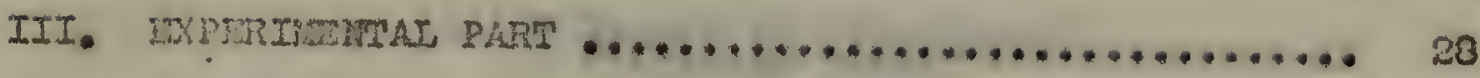

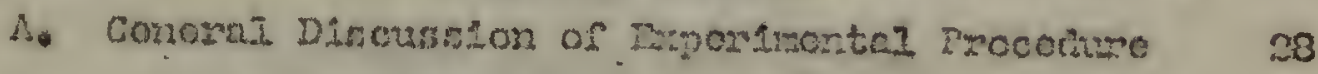

I. Cholec of Jothod.

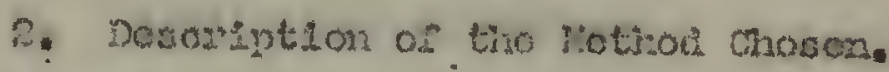

3. Watorsinde verec.

4. Apoveratus Oenc.

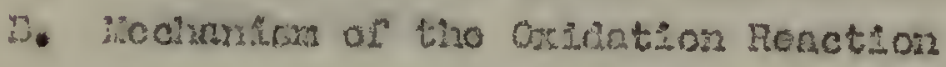

1. Cormonison of the Rolatsvo Iusctions of liuzanero Vu-

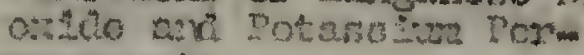
mencerate

(a) Fato of pemangancto in Solutions Continisine WhuCanotrs Iors.

(b) Dae of langanoso Dioxide in Diace of resmenganato.

(c) Compromison and viscusoion of Fosulta Ualne Varlous hancanoso Dsozilo proparationt and losramganate Solutions.

2. The Decurzonce of Hancarze Phosphato

in tho Dridation Roaction

(a) Dosowiption and Analgsis or inarm canle Mospinte.

(b) Soluvility of Mangaric Phoophato.

(c) Nolacion to tho oxidation liochanitu.

(c) Erroct of solisblo Muorphato on tho

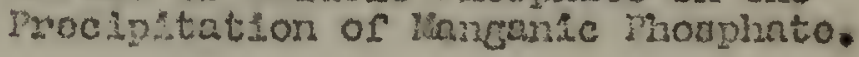




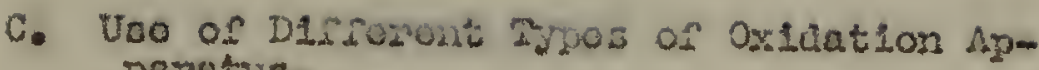
parestus.

52

1. Roration procociuro.

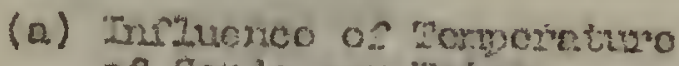
of Conderisor "intor. (a) Vinrzuatco of Itypo of con-
connor.

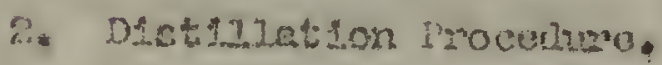

D. Frfoct of Pronionsc Avie on tixo Dotormination of Lactic Acsll.

I. Doturannetzon os Iactic Acid In ferrantine

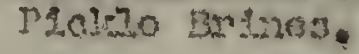

1. Doseription of the sarplon hndyod,

2. Doformination of mitribjo faldity.

3. Detorgucrat:an of Jectic Acla by Oxidation.

4. Cormarison and Diocussion or Rosultis obtainod by mitretion and oxiantion.

T. SURARX

ca

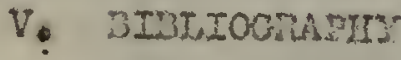




\section{IMPTODTCTIAM}

B. Imstonicnz

The clotormantion of the oract suount of lactic ncil

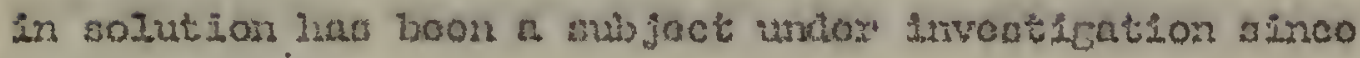

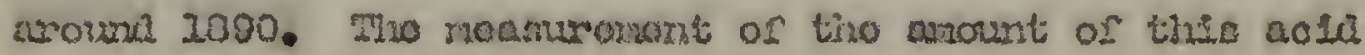
In ratura.1y formontod bovaragos has boon and is still bolng

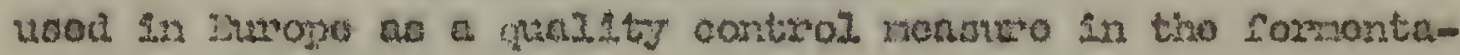

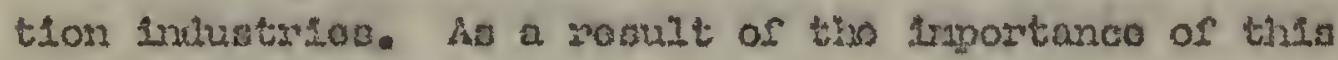
dotomanation to tho formontntion instustry, many of tho oarly

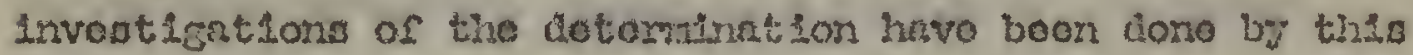
Goup and appour rmoquentiy in tiso Eronoh, dorman, and otlor Turopoar journals of tho fool and boverago industrios. Tho

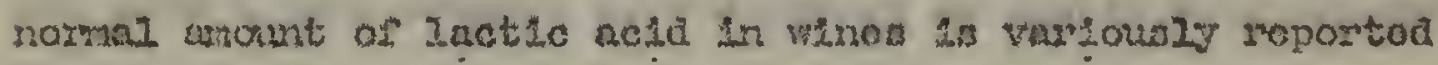

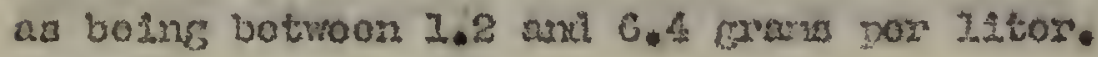

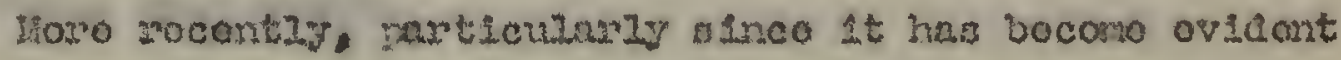
that lactic acid Ifobably playo an 1mportant rolo in tho

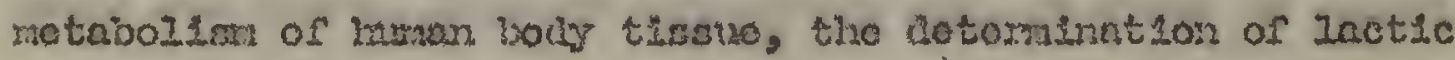

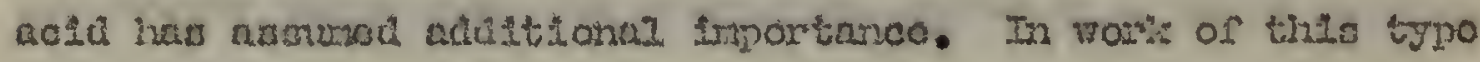

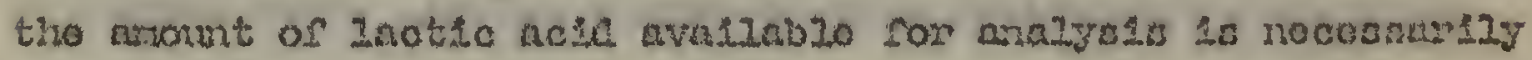
mali and It has bocamo ovidont that tho nothods of the vino

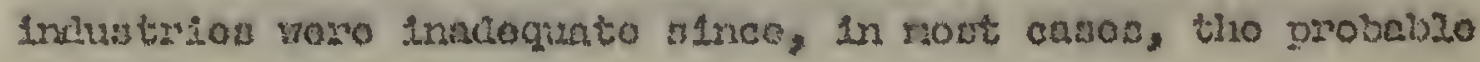
crmor wonld oxcoou the totnl monnt of zactio acio in tho anmio. Worlore st thle nowor 1 ino of inveabigation thon turned

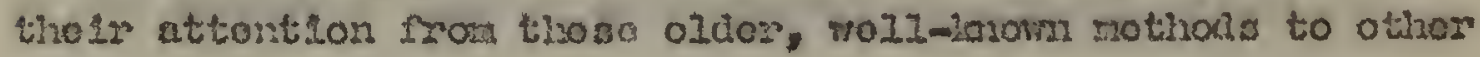




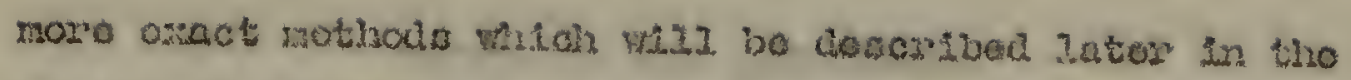

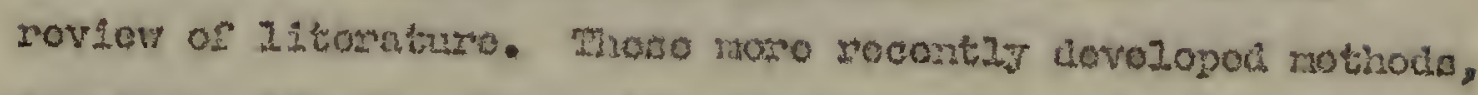
tocothow whth the old routino notiwaso of tho fornontation

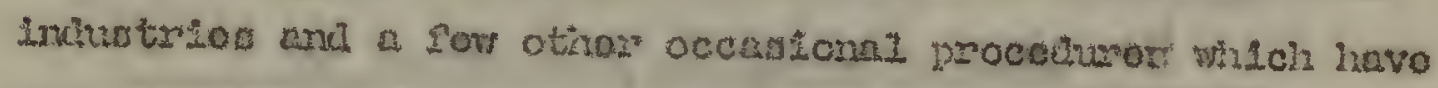
boon lovodoped ros apecinl use, roprodent tho rasority of

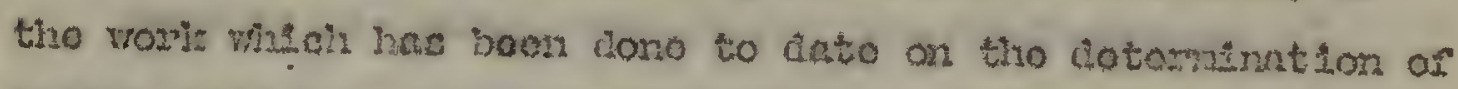
Iactic acir.

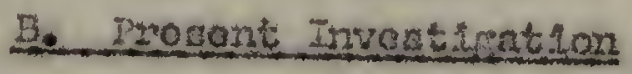

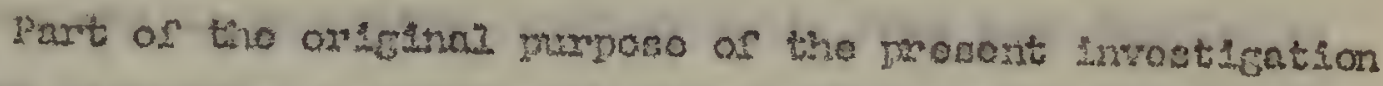
wan to menture tho anount of Inctio nele whois is protont In cortain fomont bactorlaz rornontution of curgare to Inctic acil. Sinco obhor

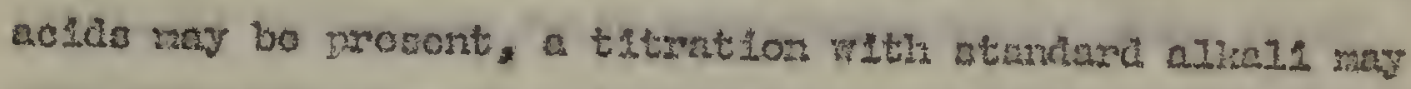

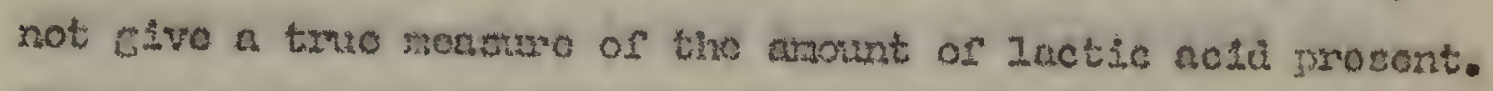

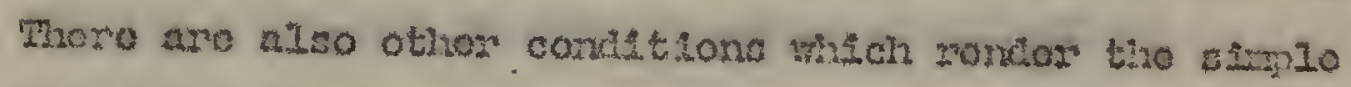
tatretion 3rachumate.

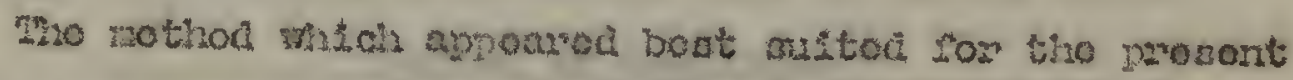

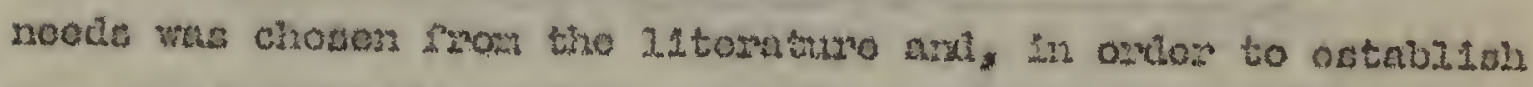
tho propor tochrifuo, tho nothot vac tritod on a lasom solution

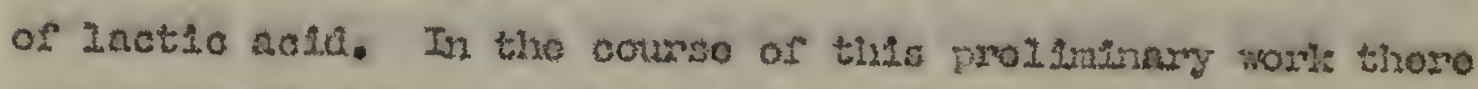
aroso cartain theorotical comidurations as woll wa cortaln

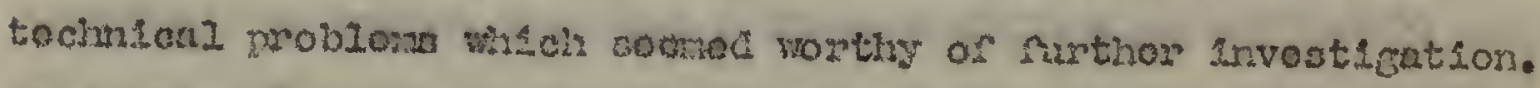
It is tizo MIan, thorerora, to prosent the rindince of tho Invostigation on tho motrod, ard ruthor, to rairo a comarsison of tho wrount of Inotic acia prosont in eppleal brinos as

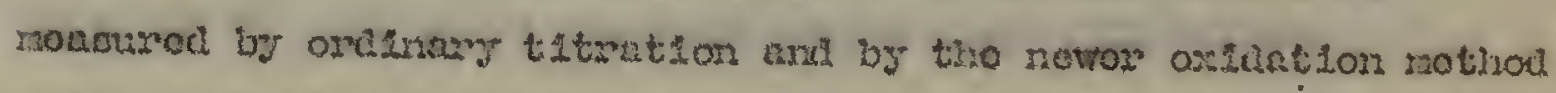
which is bollovol to bo moro npocirlo for lactic ncil. 


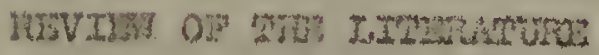

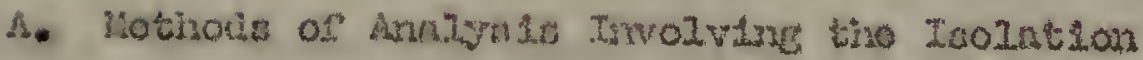
of Lactsc Acge as Luxy Inotato

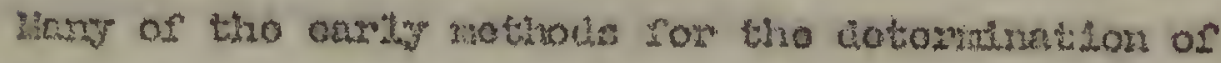

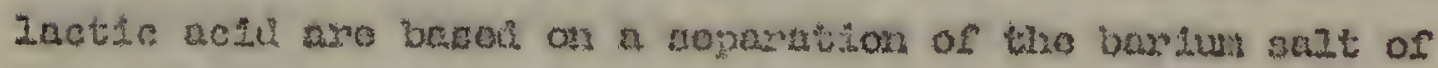
lactle cald in alcoixol. In a noludion of 75 por cont othyl

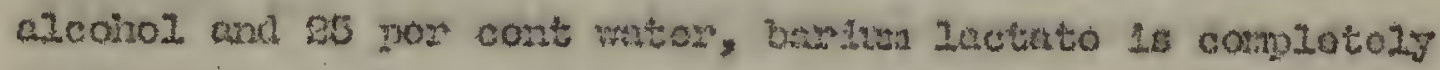

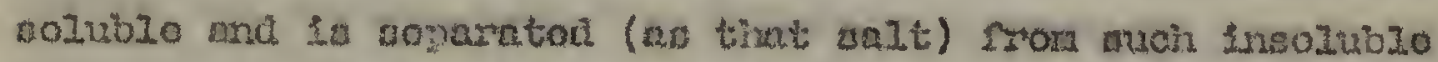
bnelun compormis as barlua clirato, tartinto, and aucchnto.

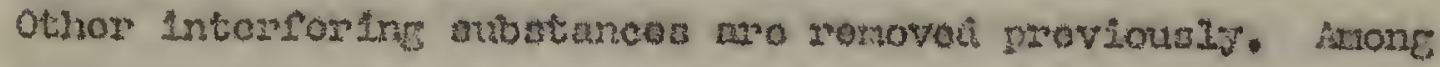

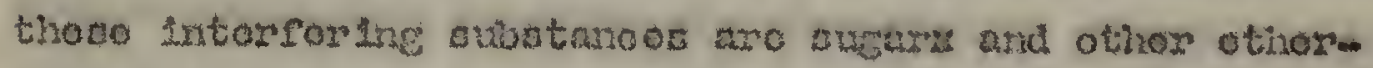

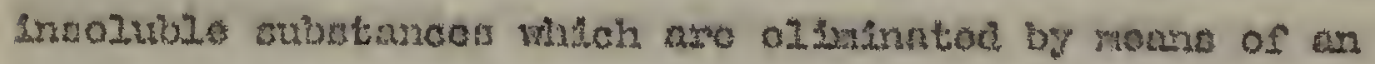

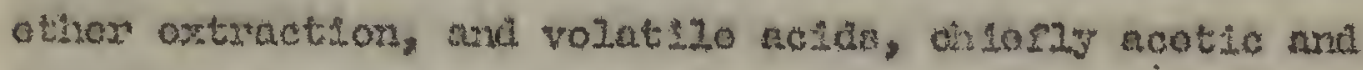

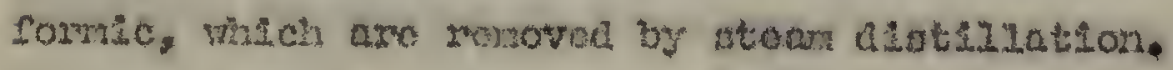

1. Dotcratration of Lactic Actet ae Darium Oxilo

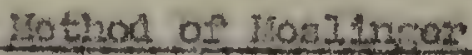

Losldreos (1) in 2002, worletag on tho detormination or

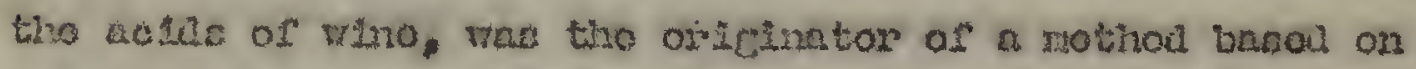
the soparation of bastum lactate in 75 pos cont alcoinol.

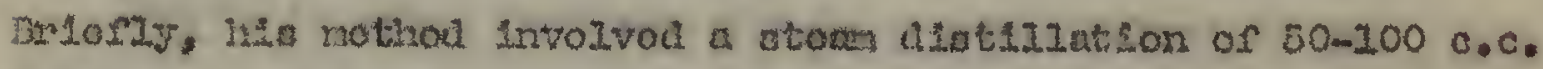
of wine, collowod by noutsalssation of the rosiduo vith bariter

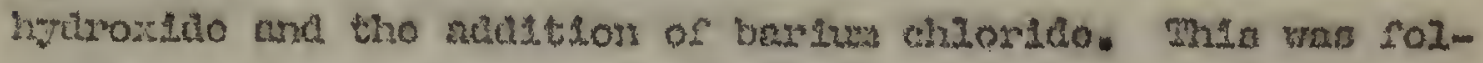
lowod by cwaporation on atean bath to 25 c.ces and tho adaltion of 75 c.c. of of por cent nicolnol and riltration. 
Aftor ovinoration, tho siltrato was ashou and tho amont of baxius oxilo prosunt lotomingu by lisect istration. Iro alkazintty of tio arh wae a rencuro of tho Iactic acid pronost. Tho nothol was ratron cimo but wh ronsonebly

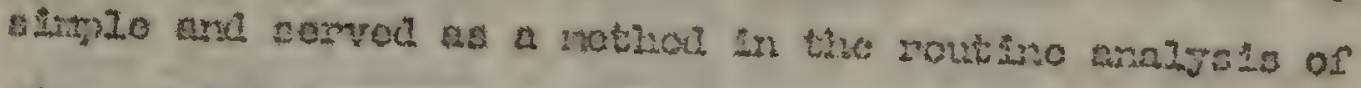

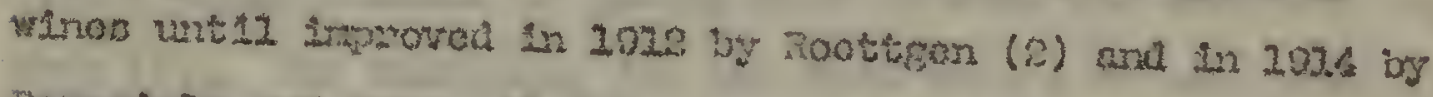

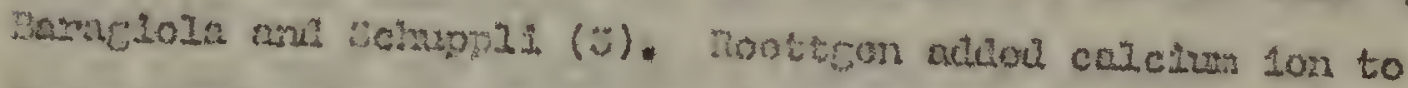
tho solution jugt borode the nduston of alcohol, whic

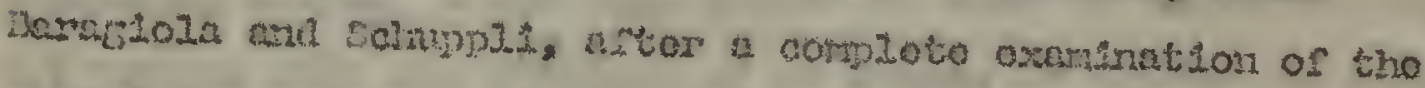

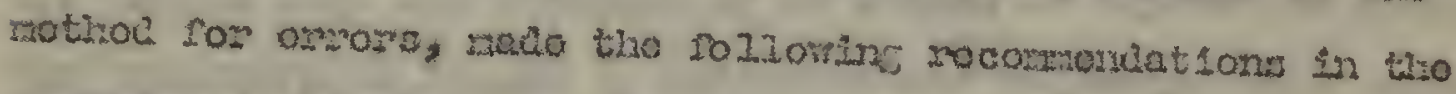
procolumo: firet, romoval of tio axooss of bardum chlorido

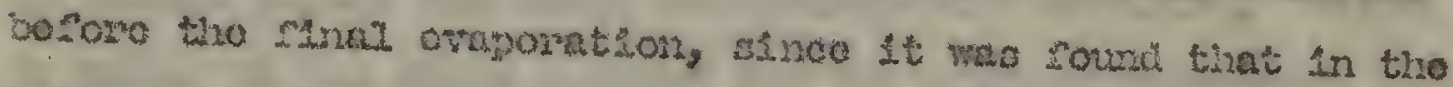

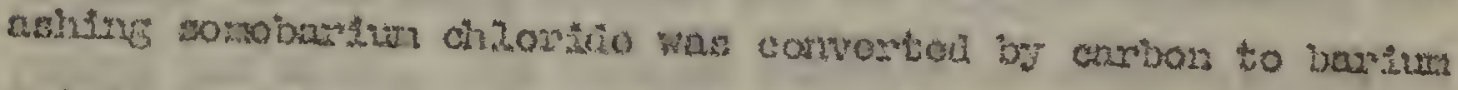

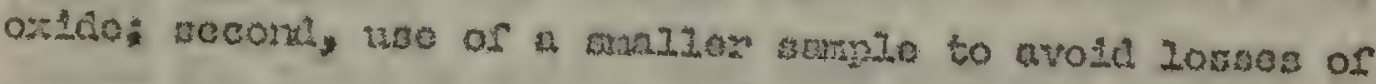

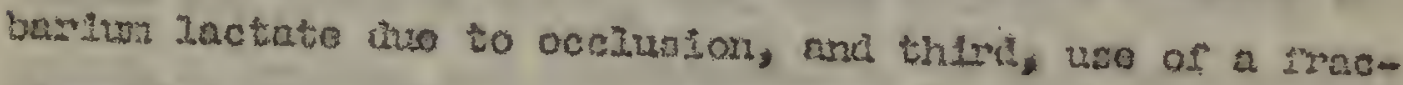

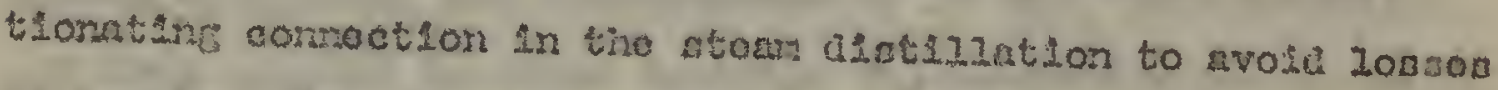
of Iactic acid. Inoso sarig authorg (3) malo this statoront:

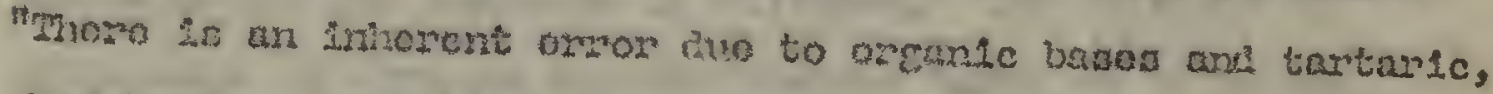

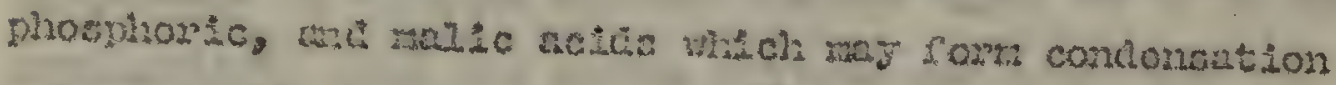

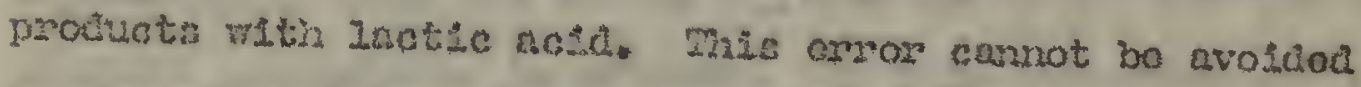

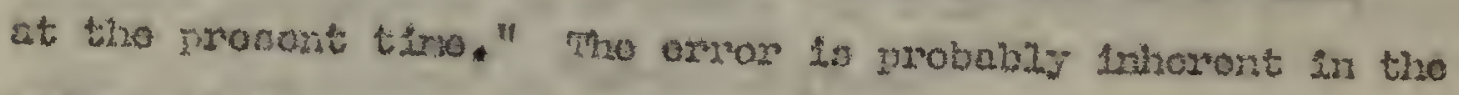
notinos at tho prowost tiro.

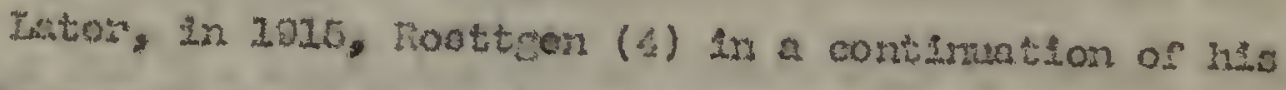

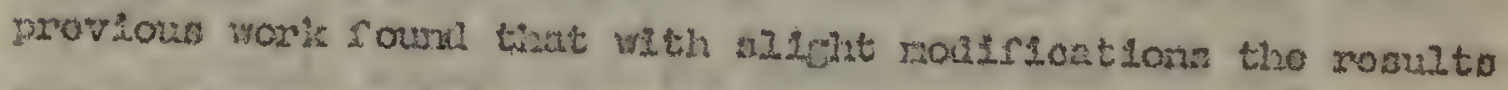

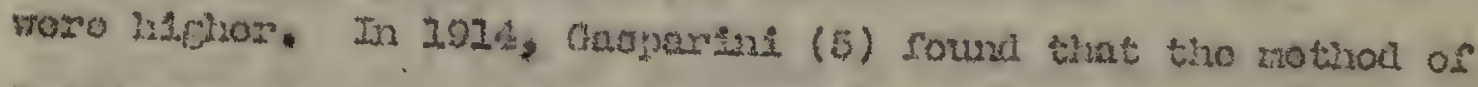

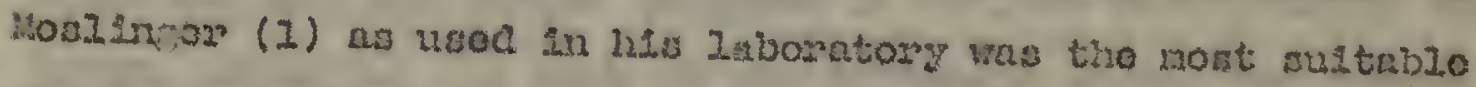

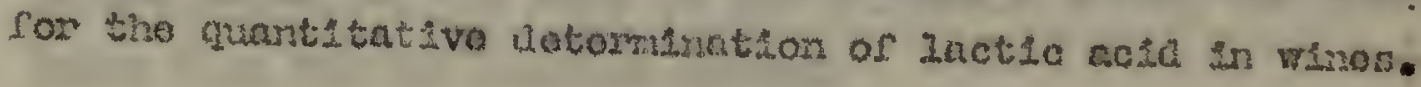




\section{Dotomination of Lactic Acto an Bartura Surnote yotyor of gans}

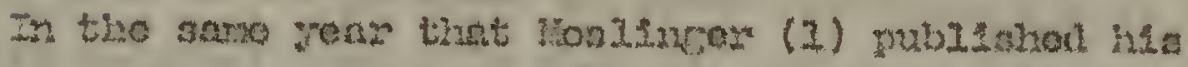

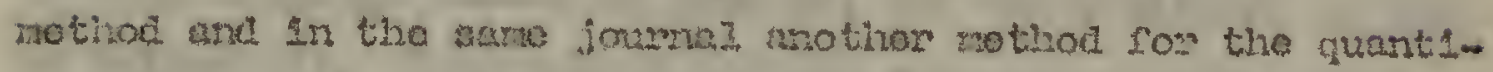

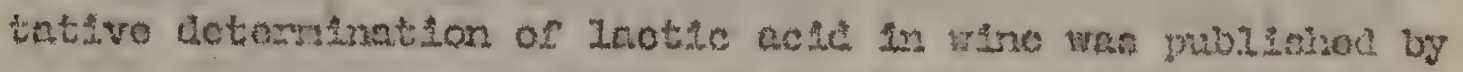

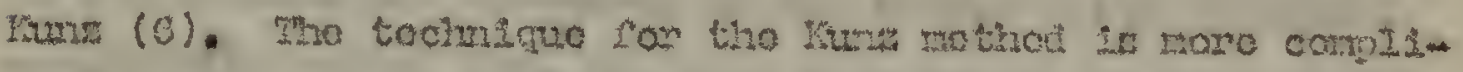

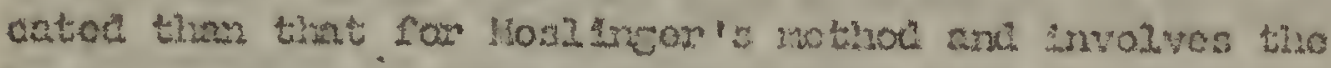

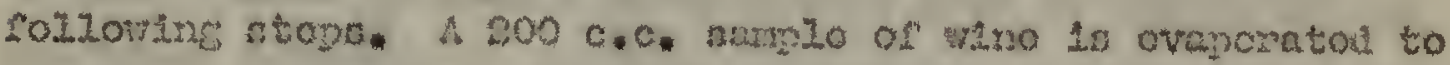

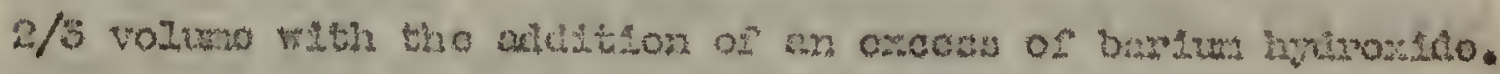

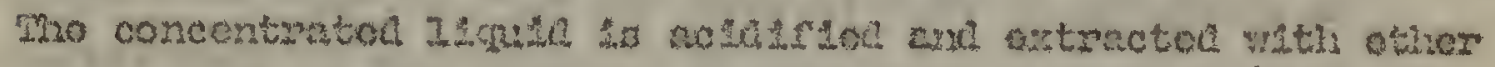

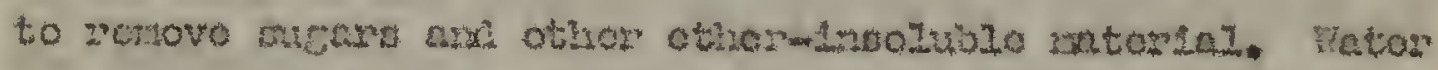

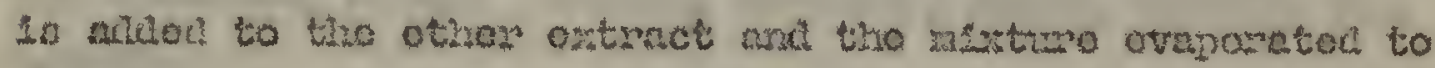

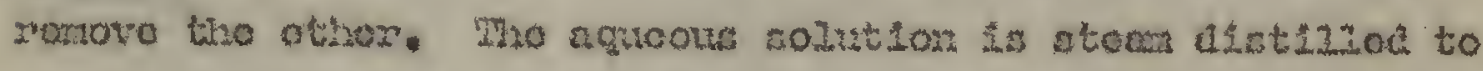

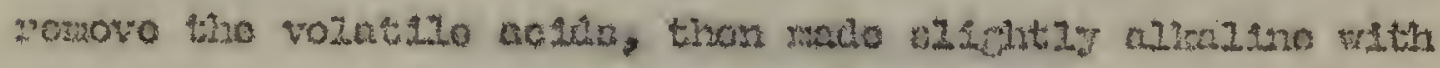

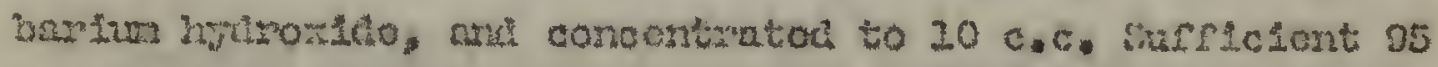
par cont alcchol to added to bring the concontration up to 75

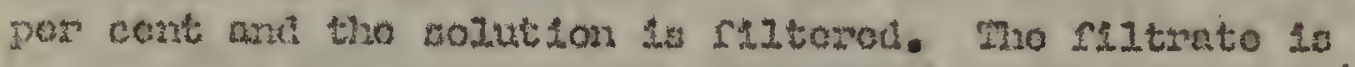

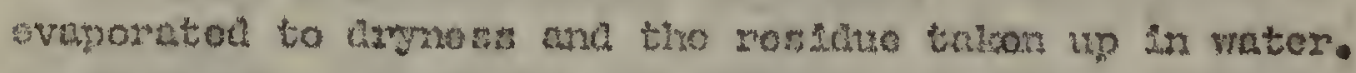

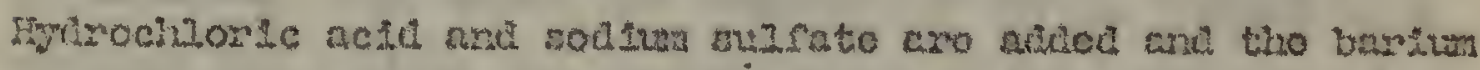

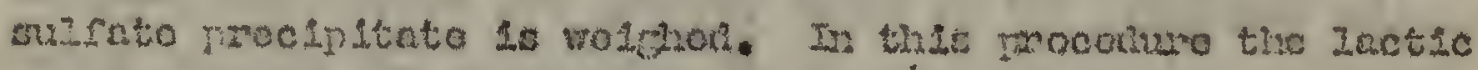

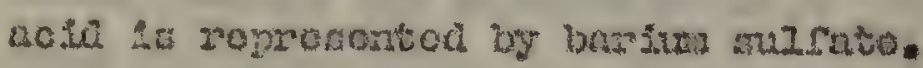

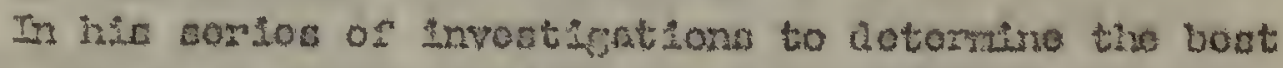

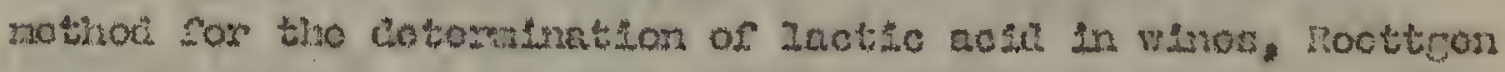

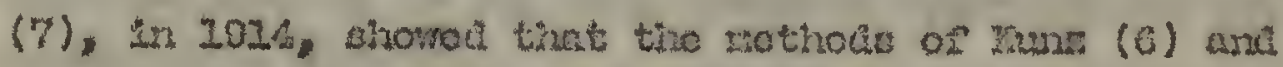

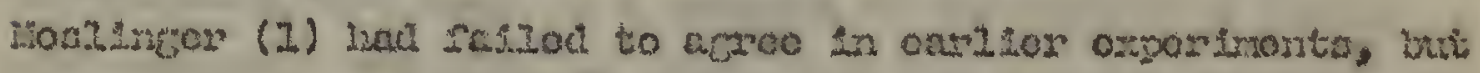

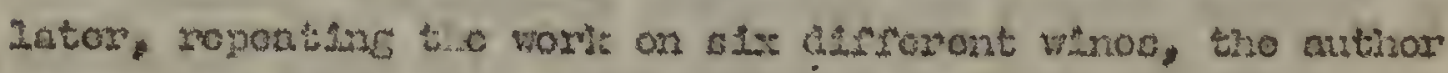
comal skat the two nothoda aprood. 
A.O.A.C. Hothod. The ofricial motinol of the Associntion

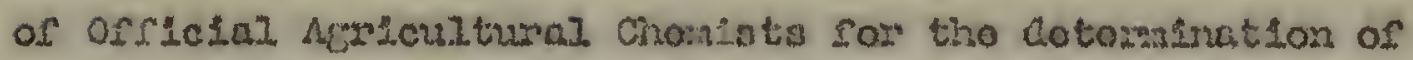
lootic acta in tho protonce of othor organio ectas 28 basou on this oriegnal method of thrnz $(0)$ and was publistou in 2026

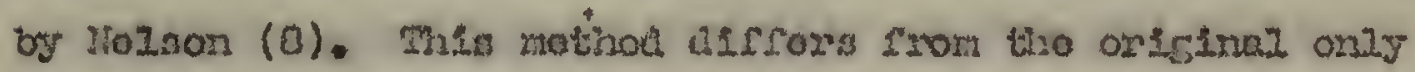

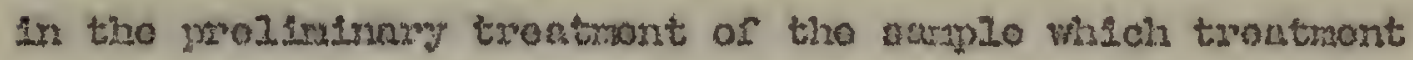
necoesarily vastoo with the typo of natorind to bo analgzen. An snprovemont in rado whoroby lnctic acid is liontiriod in tho final sultrato by crystals of culnino Inetcito. The motisol civos from 02.5 to 37,0 nom cont on 0.08 to 1.0 grane of lactic noll in tho nuenonce of 0.20 to 3.0 crmas of ach of tho following acide: ctertic, tartarlc, malle, acotic, and bonso1c.

\section{Ston astrat ton llothod}

Anothor gonerwi rathod for the dotaminntion of lactic ac10 baseal on a soparation in 75 port cont alcolvol solution

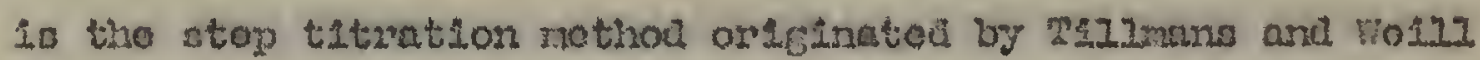
(D) In 1929. The nothod was dovioed for use in routino vino analyase and follont the generel stope of the Mosingor (1) rothod through the andarntion in 75 pos cont alcolnol solution. After hocolarisation, tho filtrato in titratod wits 0.11

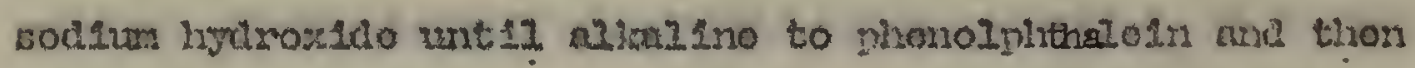
titrater back to nil 3.2 with standard wrirochloric acte. The hydrochlortc acta usad is a moasure of the asmount of lactic acsd prosont. The nuthors clntn tint tho rosulto obtalnod by this rotirod agreo with those obtalnod by othor mothods. 
Tho clains are aupportea by en lnvoatlgation sn $1930 \mathrm{by}$ Ruffy (10) as a recult of which ho Focorrandod tho ntog ti-

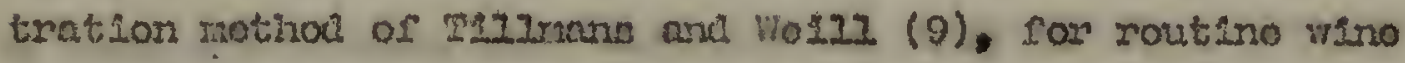
analys 12 , although for accurcey tho proforrod tho losistgor

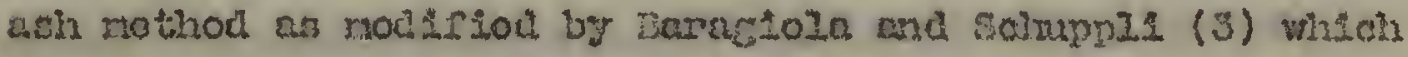
was abcusaod on jago

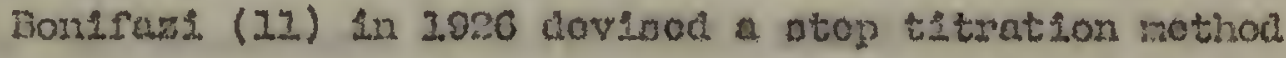

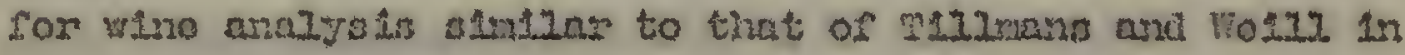

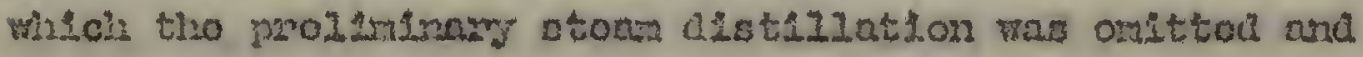
Ioctic and acotic acida voro neanurod togothor by tho acid usod 13 bacle titrition. Acetlc acla was twon dctorntrod by

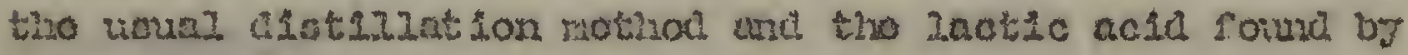
alfromonco. tho noxst of this nothod was clasuod to ront in 1tw rnyiaty. Fomita showod it to be co accurato an tho or-

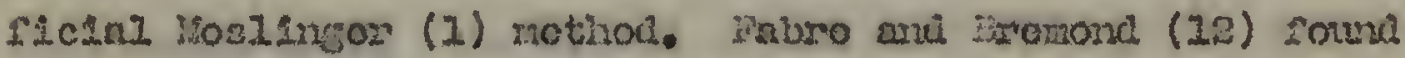

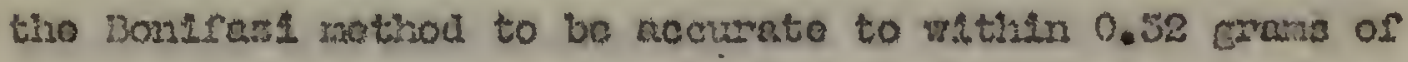
lactle acil por liter of vino.

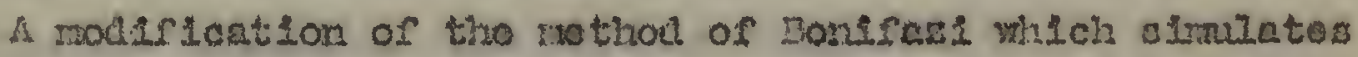
tho oxictund mothod of hoslincera was dencribod in 2031 by In 1 chol (13). Instoal of titmeting tho alcoliol filtrate,

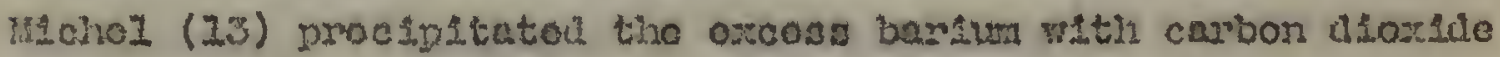
and ashad tho ilitroto. The alleringty of tho ash wa n

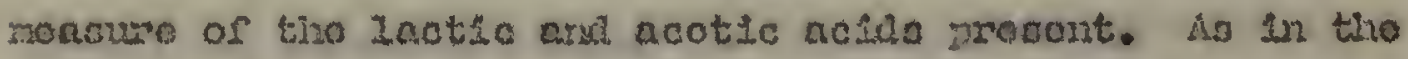
Wonkram 1 motiod tho andont of ncotsc actd had to bo datominod by distisization.

Mnong tho monsoun for the oraporation of Inetse aclo

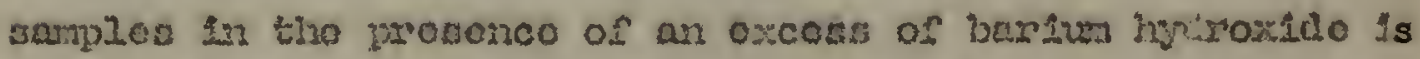
tho convonglon of an apparantIy momally oocuratne lactse acte 


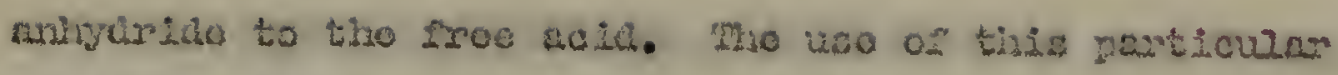
alirali for tho contorsion was tho ousjoct on ex Invostlgation

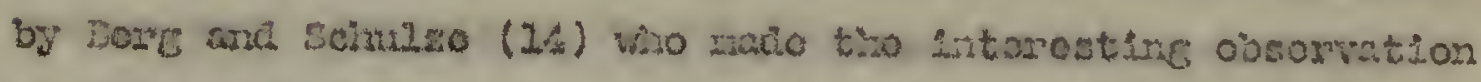

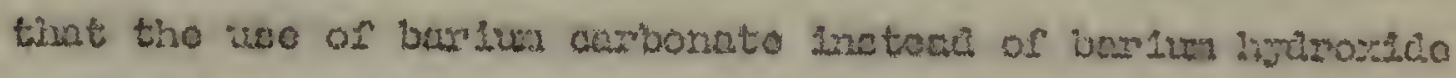

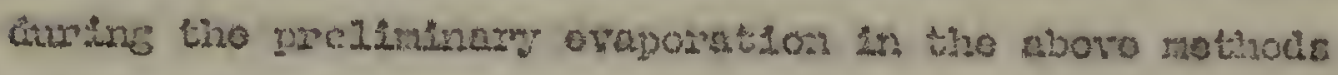

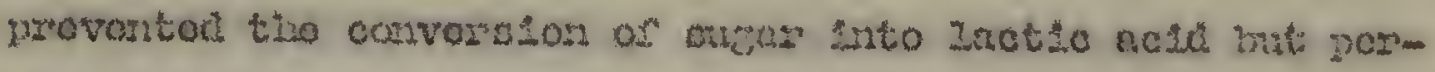

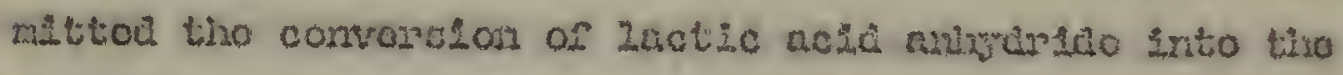

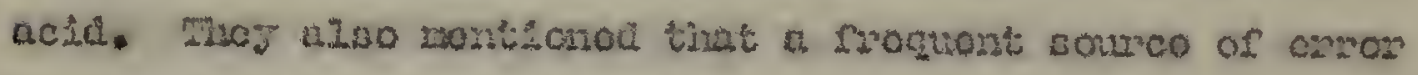

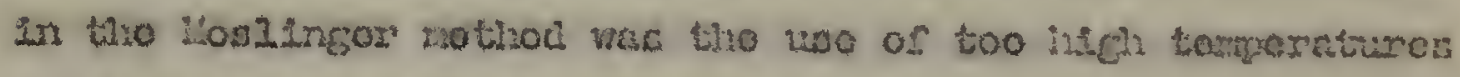

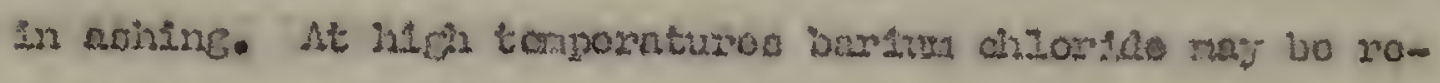

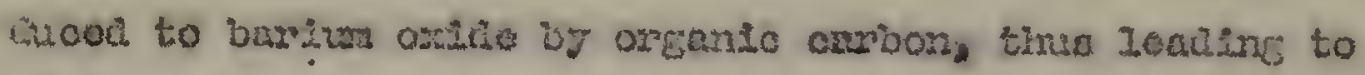
Wigh rosuzto.

Sonvogin rand cant (15) in 1952 sace tho rout recont

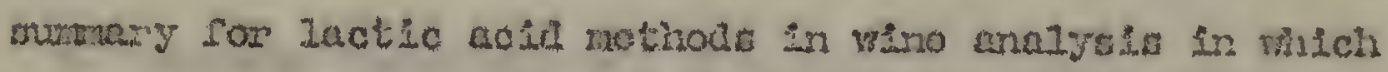
thoy state trat, "tho mothod on Domifazi (II) chvos good rom sulta wizon tho Inetic acil contont is botwocn cno and fon

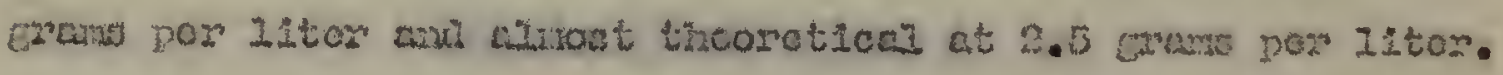

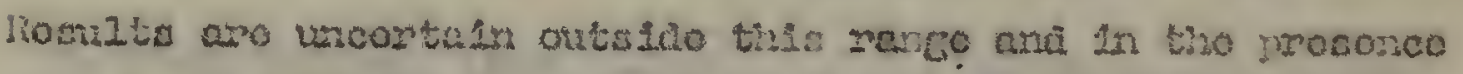

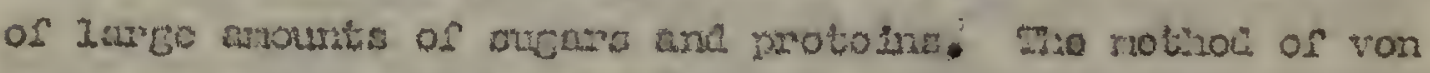

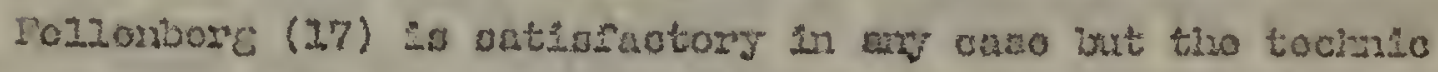
is Involved." the nethod of von Ealionbons (I7) nantionca

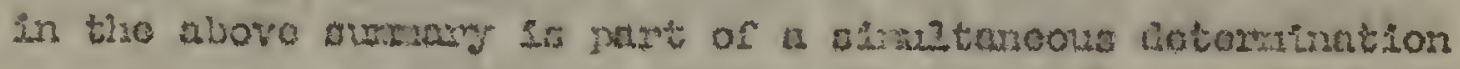

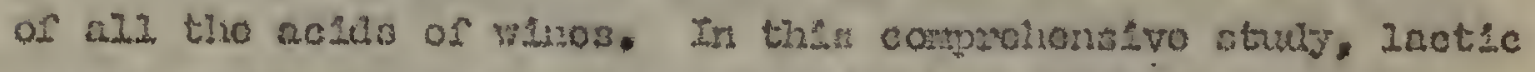

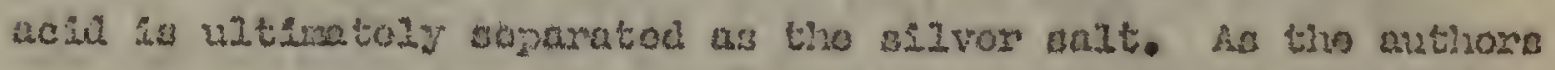
monicioned, tho frocoluro in oxtronoly involvod and is tima wrisultod for routino analy 10 . 


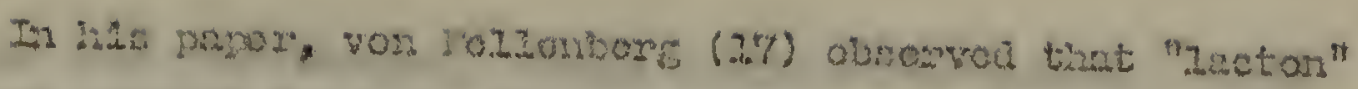

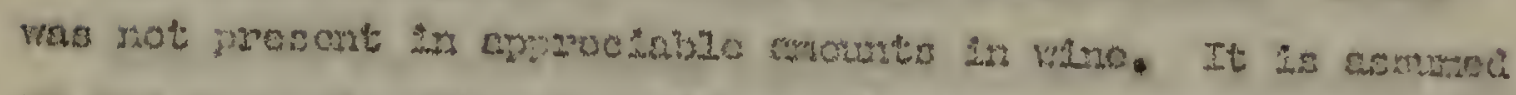

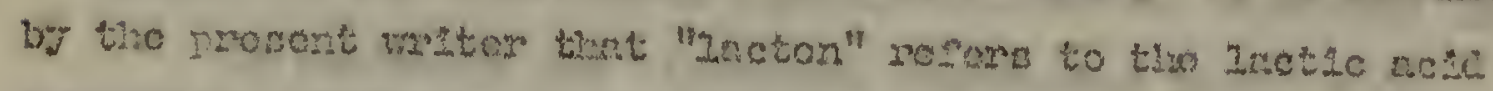

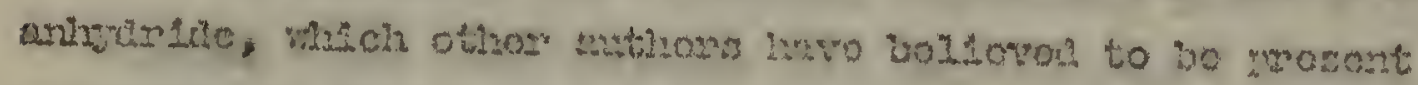

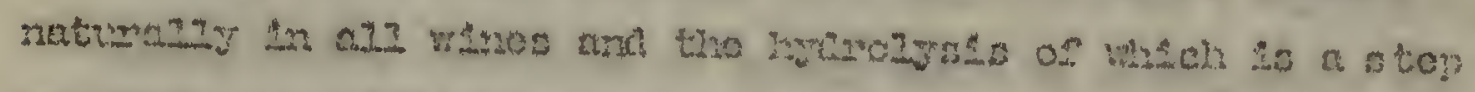

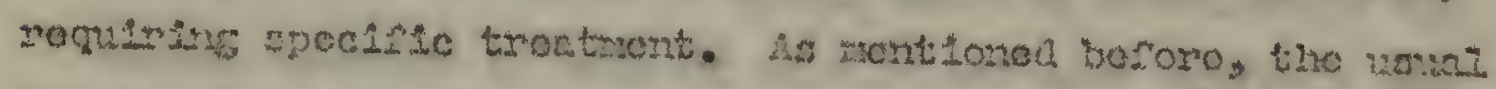

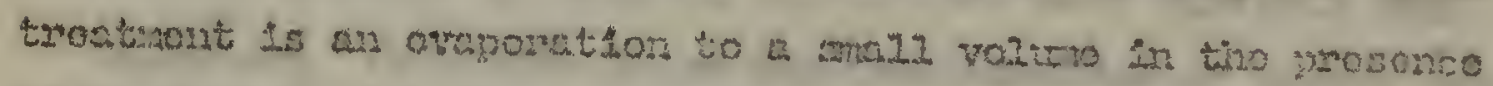

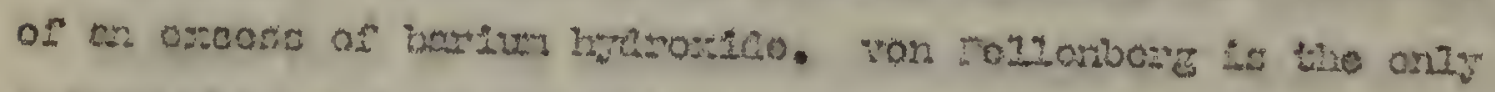

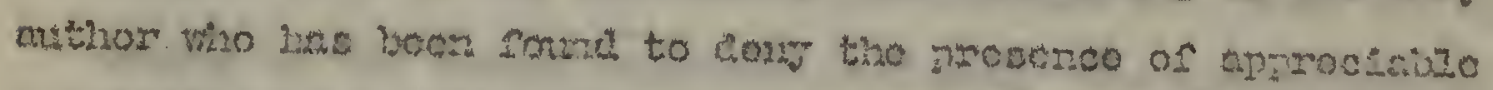

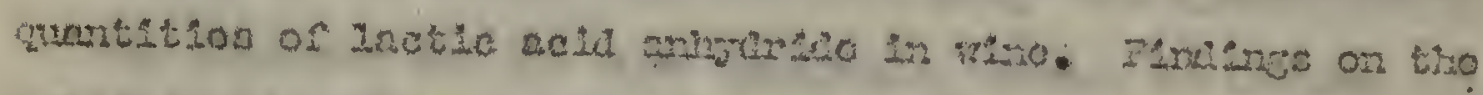

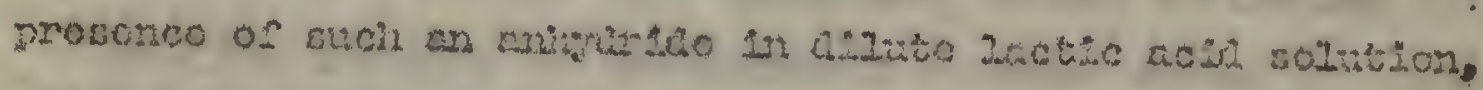

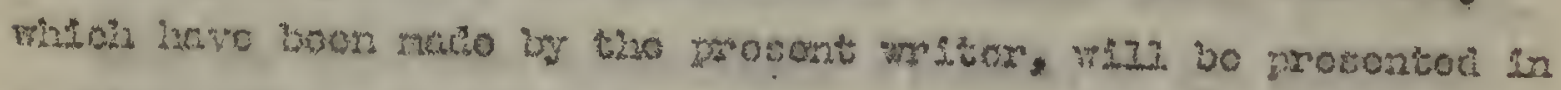

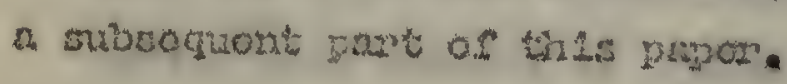

5. Hothole Inwolvtno tho Gxiation of Iactic Acid

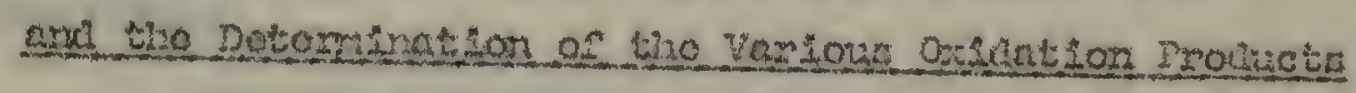

\section{1.}

In 2032, cacusan (10), worling on tino Inctic acid contont

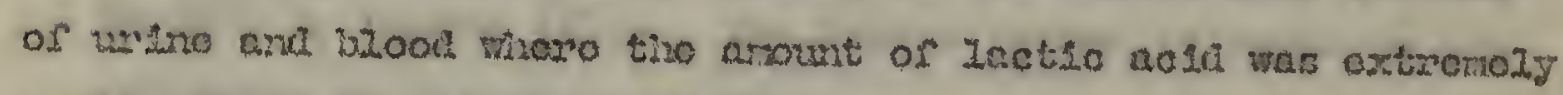

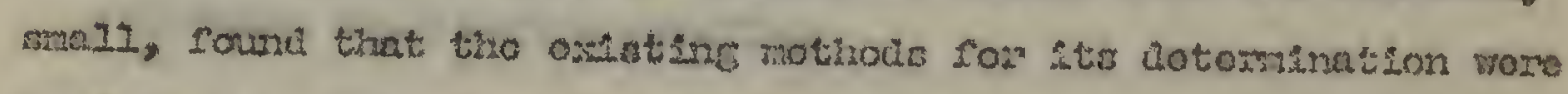

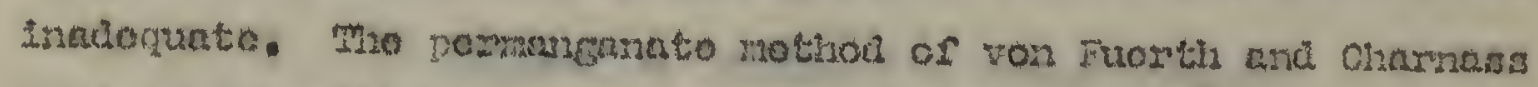

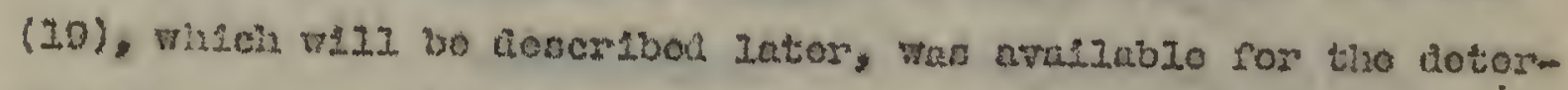
mination of cuantitios of Inctic acü crontor than 10 or 20 ras.

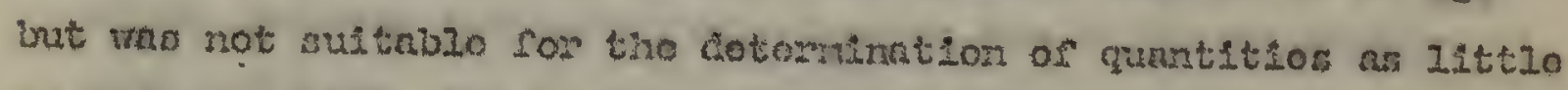

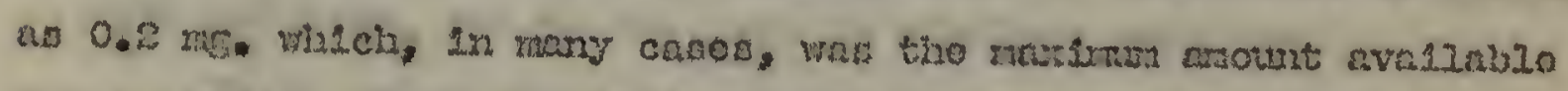

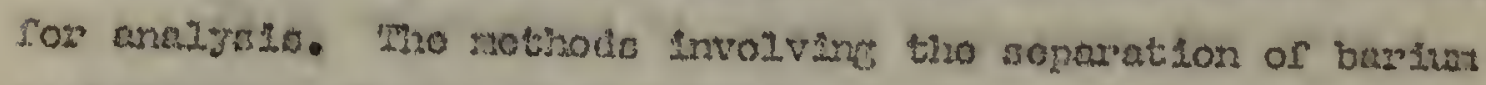

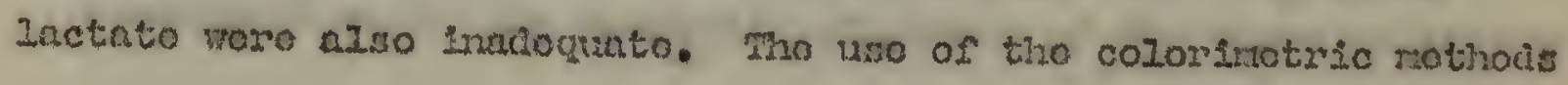


wat alno alccoumoroa. Mose coloxinotric methous, wish annow in tho moro pocont 11toreturo, $\$ 111$ bo montsonod 1aton. In revlowing tho iltoraturo concomine lactic acla, Clauion foura time lioscanor (zo) ind roportod a aucceserul

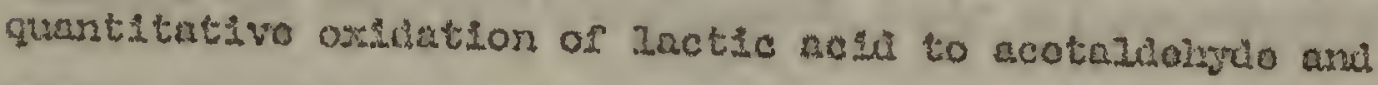

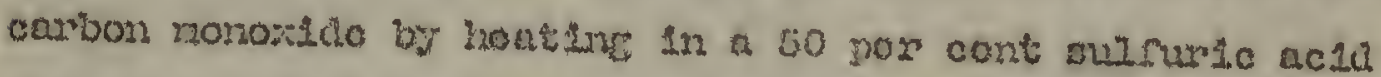
nolution. Frov then posnt tho dotomination of lactic actu

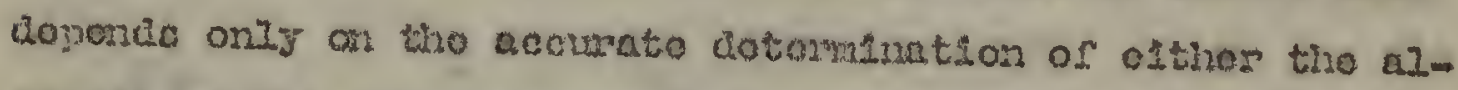

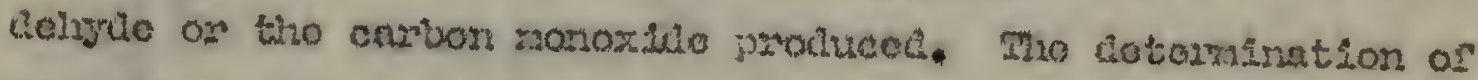

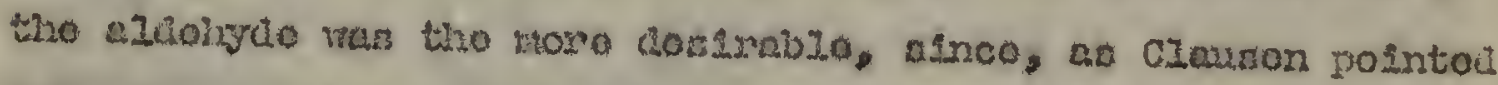

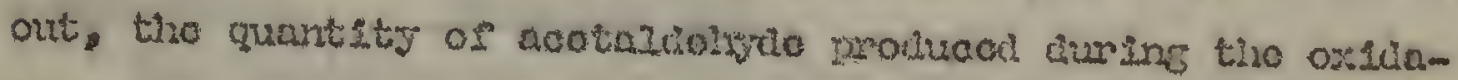

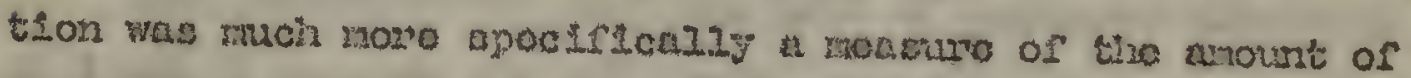

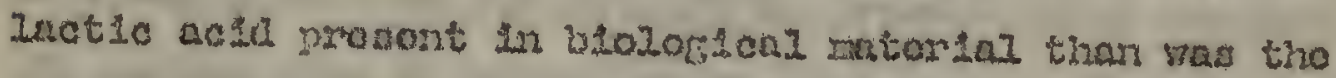

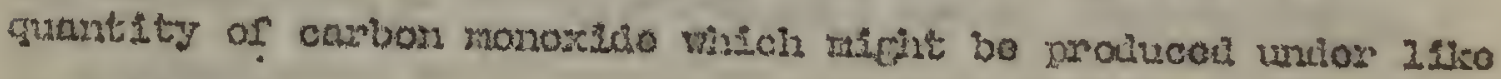
comaltesons.

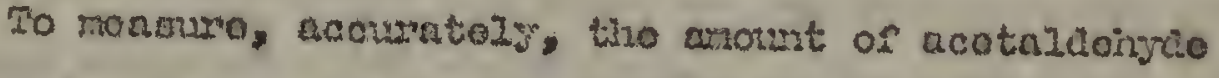
producod, clawson than mado smprovanonts on an old mothod for tho dotornination of acotalconye, whoh hal boen wubltalhod

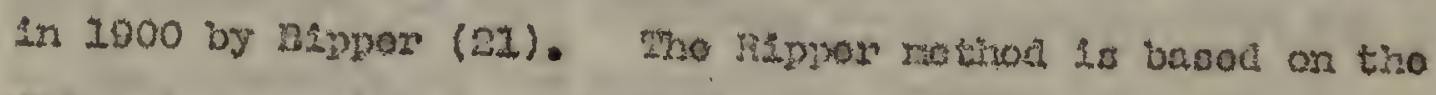

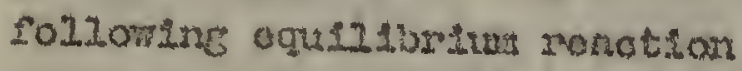

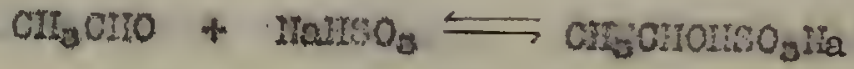

$$
\begin{aligned}
& \text { acotaziuldrio }
\end{aligned}
$$

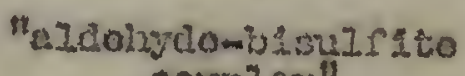

$$
\begin{aligned}
& \text { conxile }
\end{aligned}
$$

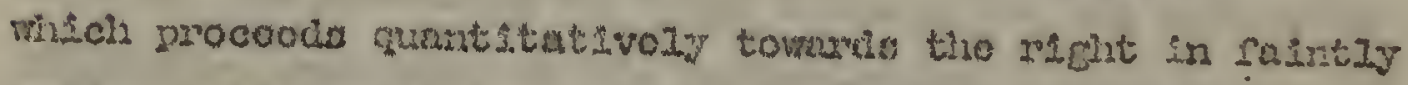
acid solution, and to tho loft in arkendino solution. It 20 intorestinc to moto th tisen point that frars a consteration of the oloctonic whmeture of the throe moloculos 
involved in tho aldehyde-bisulfite equilibrium, it could be prealcted that the reaction would go, as it does, to the right in acid solution and to the lert in alkaline solution. The following schematic drawings show the acetaldohyde molecule and the bisulrite fon with their valence electrons:

\section{Ker}

- electrons from C atoms

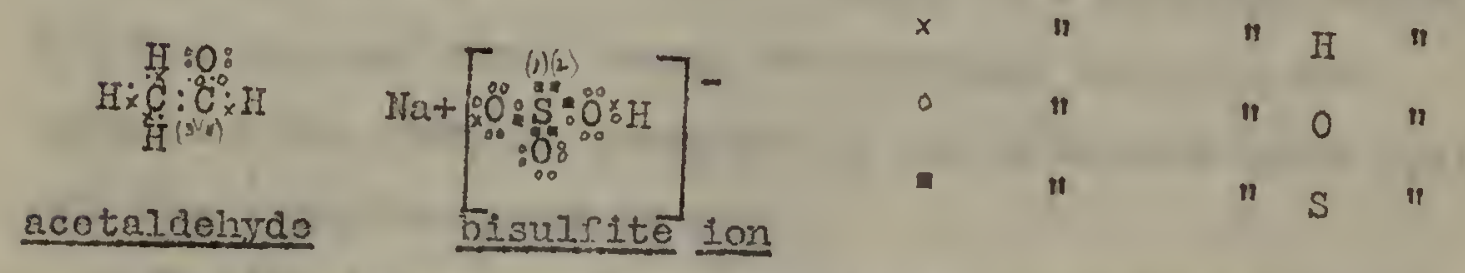

The bisulfite ion with its pair of unshared electrons at $I$ and 2 posscss the ability to present those olectrons to the carbon atom of acctaldehyde at 3 and 4 . The transfer, if accomplished, rould result in the occurence of a carbon atom with 10 electrons and would bo impossiblo except for another clectron shift which occurs at the same time. Ifydrocgon ions are lnown to show strone electron-sharing tendencies, and, thereforo, in acid solution, it is possible that one pair of the olectrons in the doublo bond botween the $\mathrm{C}$ and $\mathrm{O}$ atoms of the aldehyio is pullod away from the carbon atom to satisfy the valence pull of bydrogen lons, with the formation of the Iinkage $C: 0_{0}^{0} \quad$ in place of tho Iinkage $C: 0_{0}^{0} 0_{0}^{1 b^{3}} H$ as bofore. The electrons at 5 and 6 then, are the pair which originally woro part of the carbon-oxysen double bond. By this shift, therofore, it is possiblo for tho sulrite lon in acid solution to impose its two electrons on the carbon atom at 
3 and 4 With tho romation of a comound with an clectronic strictume as foriows:

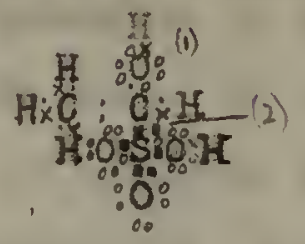

Fron tho abovo discussion lt follows that tho formation of auch a compound is posibible only in acid solution, and similarly, that tho adiltion of alkali to a solution containIng the cormound rould ronove the hrisocon fon fron the oxgcon of the aldehjte Eroup at (I) and thorororo rould aplit off tho bisulfito group at (2).

Rippor macio use of tho roaction towards tho reicht only, absorblin the hichly volatile acetaldelyde in an excoss of standard bisulrito and titrating tho excess olsulrito with standard lod1n. The amount of biaulrito bound by aldohyde, and thoroforo tho arount of lactic acld orieinaliy prosent, was lotorminod by tho alfferonco betwoen tho total amount of bisulfito and tho excoss as loteminod by titration, The instablify of the bleulfite solution on standing for only a few minutes causou orwors wilch claus on ollminatod by making use of tho rovorso roaction in oquation 1: Aftor romoving tho

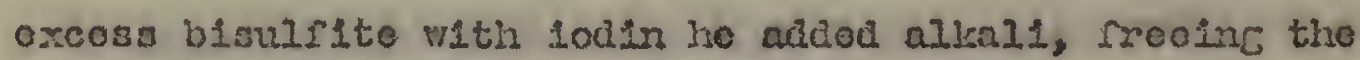
bound bisulfito, and Irmoalatoly titratod tho bisulrite, thus libcratod, with standard lodin. Wre ancunt of louin usod in titrating tho bouni bisulfito waz a moasure of tho amount of lactic acid orleinalig prosent.

clauson has citod data to ahow that tho rosults thus obtainod usine tho Lteisgnor 50 por cont sulfuric ac1d oxidation ard the molirled inppor aldoindo-bianerto titration aro 
accurato to 97 to 200 porcont of the thoorotion in puro

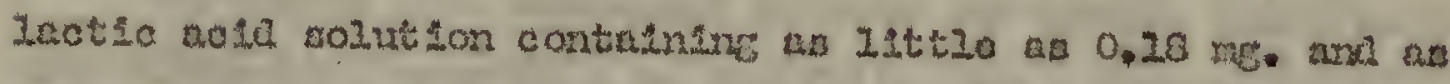
much an 45 me of Iactic acla. Ilo arro mointod out that thore aro mary sources of orror in tho thetormination wizn

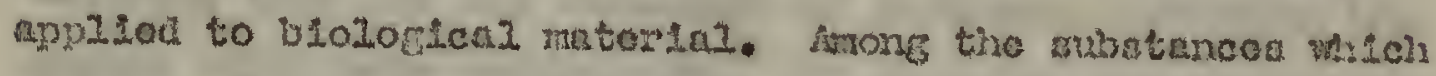

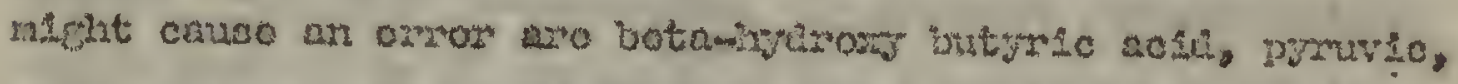

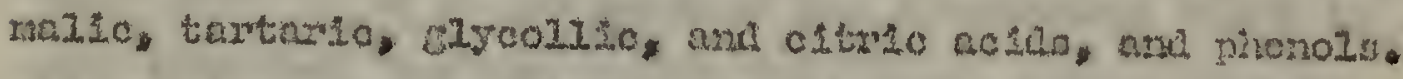

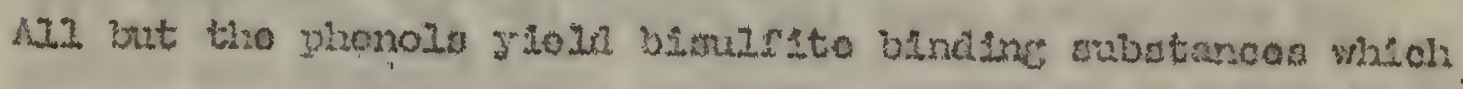

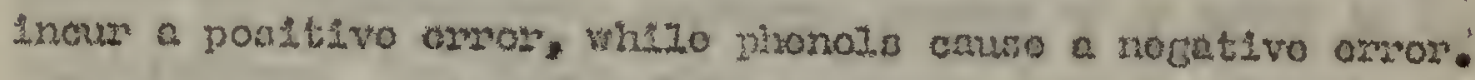

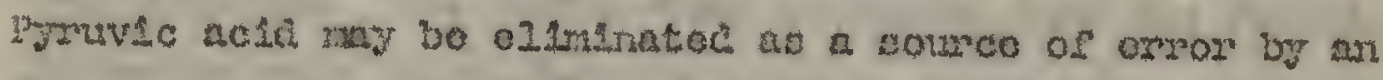

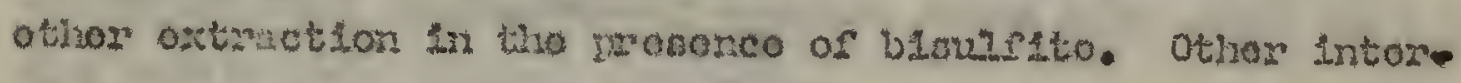

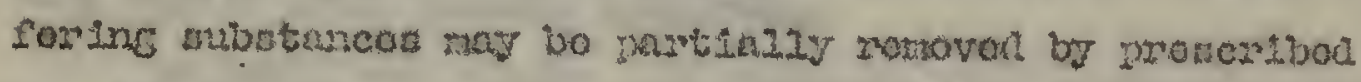
trontmont:

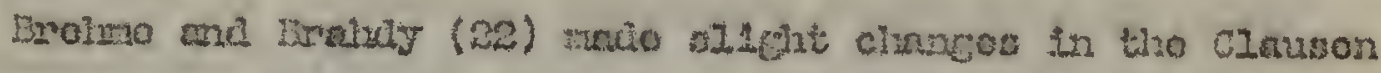

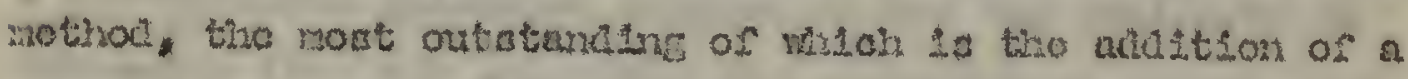
cocoml absorption tubo to inmuro comploto absorption of all

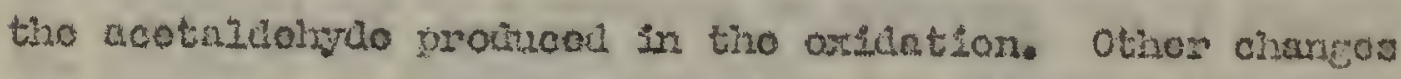

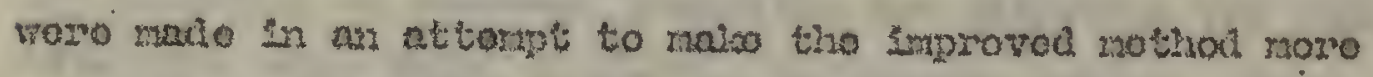
opoctic for Inotic acla than was tho original mothod.

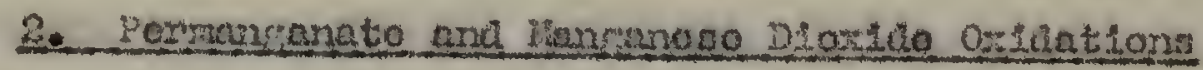

Bons (25) It 1805 sound that Ixctle acid could bo do-

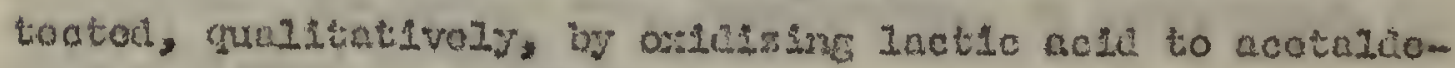

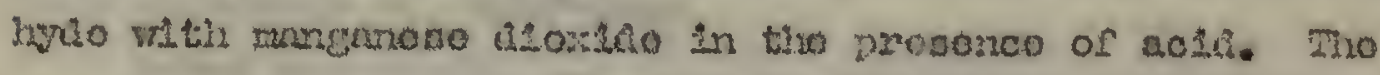

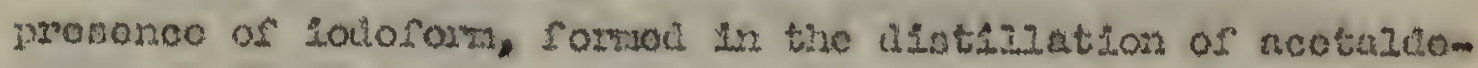
sydo into as nicoliolio solin colution, wan a ponitivo tost for Jactic acti. 


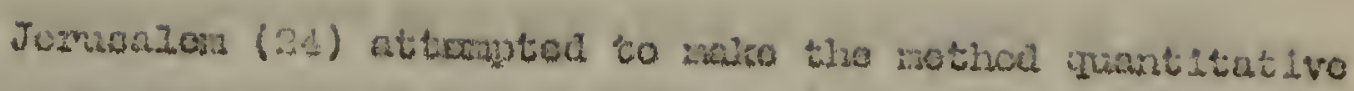

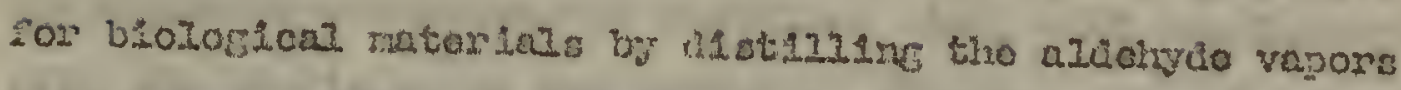
Intio vator, auking an orcoes os stendard Louln, end, artor

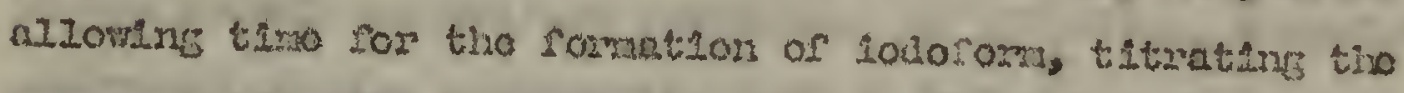
axcoss lotin vith thiomulfato. Io reported cotatrinationo which voro 92 to 00 por cont of tho thoonoticnz valuo sn pure Bolution, but von Puorth (25) Inter bizovod thint tho rathol was thoorotically inoorroct bockuse of an orror in tho crlculations. Von Wuerth niso indilcatod that tho rontits of

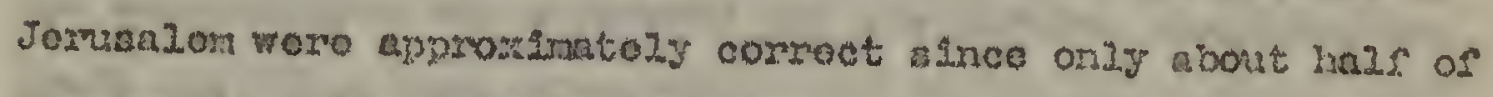
the lactio acid yioldod atholvido.

In 2010, von Frontli and Clammas (26) ovilaontly continu-

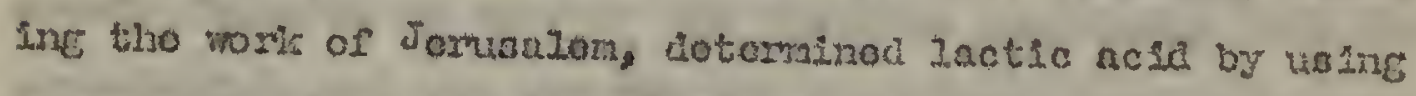

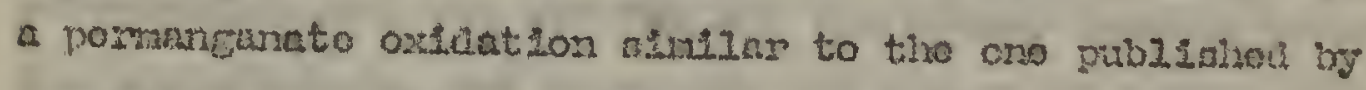

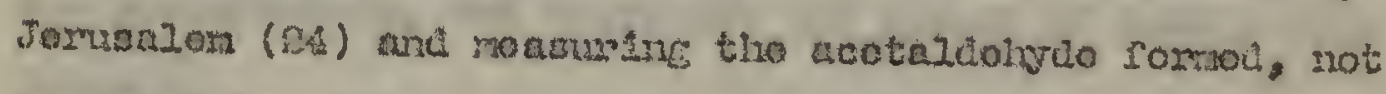

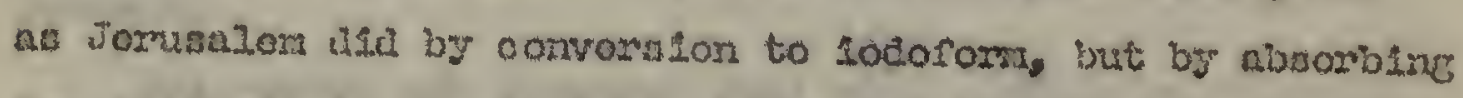

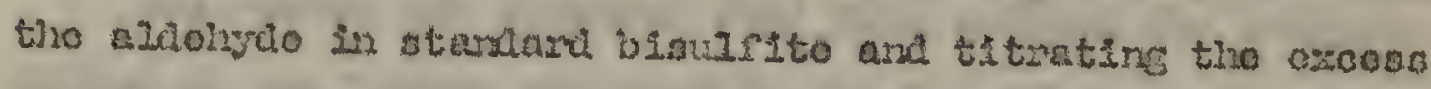

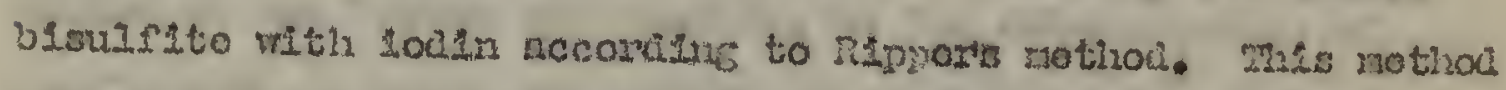
has boon mroviourly doscribod (2I). A comoctian ractor was nocossary, since only 80.2 yo: cont of a lmom, aldal Inctso

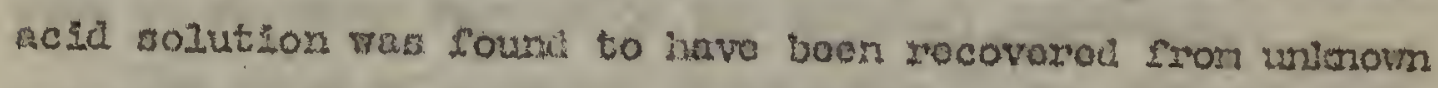

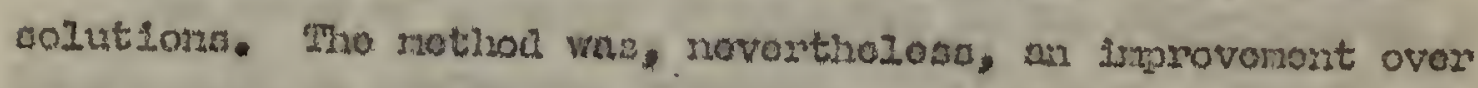

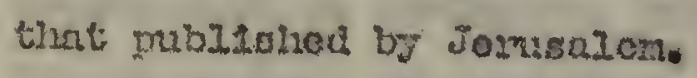

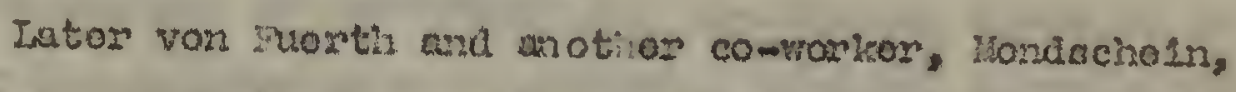
fonula an oryor in tiva provious nothou of von Fuorth and

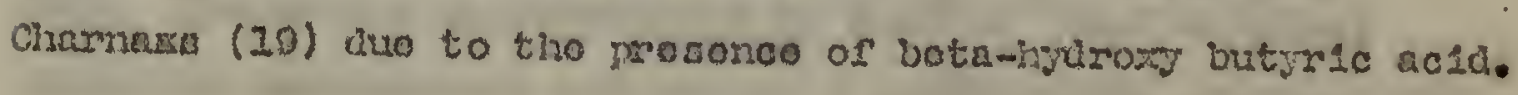


The ecotors produced thon this ac10 sis subjectod to the

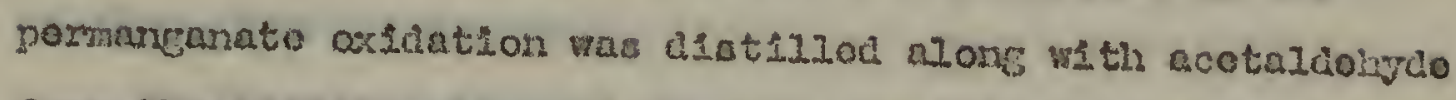
From the Iactic acld, and romed an addetion product almilar to the aldohydo-bialirito compouna. On t1tration, thererore, acotonompoduckne substancos, wuch as betamyaroxs butyric ac1d, woro noamura as lactic acid and rosults wore too high. This difriculty was ovorcome by those invertigatory by subjocting an aliguot of tho aldalydo distillate to t roatrant vith sodiun poraxida. Undor tho prescribod treatront all the deotaidehyie vas destroyol and tho acotono reminine wao again diatiliod into blaulrito. Tho afferonco botwoen tino amount of loiln usod in titratsus this rraction and tho arsount required to titrate tho rvaction containing both tho acotaldehydo and tho acotono wat tho anount used to measuro the acctaldohylo, and thamorore the comount of lactsc actd prosent.

Von Fuorth and Iehtirare (20) heve appllod tho oricinal mothod of vor Vuerth and Chamass to tho dotormination of jactic acid in urino and report cood rosults. Tho main reature of the nowor mothod is tho aotormination of lactic acld in an other oxtract of tho original subatanco.

The rirst of a sorios of nxt1clod on tho detomination of lactic acia in blologlcal matorial, yublishod as a reaut of Invoctigations by FrLolomarwa and co-rowlors, appoared in 1027 under tho authorship or Eriedomann, Cotonio, and Scharrer (20). The mothod rundumentaily is that of Bond orictnal potassium pormanganato oxidation to acotaldehylo combinod with 
Clausen's modiflation of tho Rippor titration of tho b1oulfitomazlohylo comound.

Ar 1rrortant fouturo of this first lu tho acrlos of papom by thoso worlore is tho adastion of maganous cuirato to tho oxidation motium. Tho uso of this tult in repontod to Incroase, matorialiy, the rato of oxidition, thus aliovins a shorter oxidation porsol. me ylezd of acotazdohglo 13 aso incroasca. Anothor foaturo is the use of a now simple apparatus desicnod to arfect immodiate removal or aldohyce vapors as woon as they aro forred. The mothol so roportal to be roasonably accurato far quantitios of Itatlc acla fron $0.045 \mathrm{mc}$. to $280 \mathrm{mc}$.

In the socond of tho sortos of publications, Frioderann (30) showed tint in dotormining tho amount of lactic acid in doconposing suche solution, sho analysia ustug tho mothod proviously roportod from 118 laboratory (20) Egrood w1th an

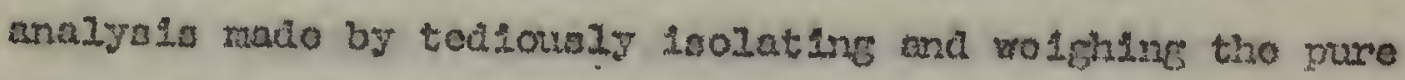
zinc salt of lnetic acia.

Iater, in 1029, FrLodoman and Rordinll (3I) found that In axalgelng conglas blologlonl nntorialo rosults woro apt to bo high boceuso of tite oxilation and slmultanoous ciotormination or all10a aubstancos. In an attonpt to o Iminato this disfleulty thaso authors malo notarnj rocomandations, all of thom in an orfort to cut dorm tho potontial of tho

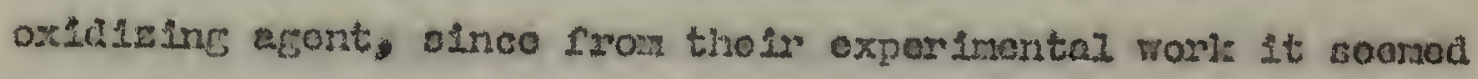
probablo thet thoso conditions mink tendod to reduco tho oridation potontial of tho syatom also tondod to roduco tho 


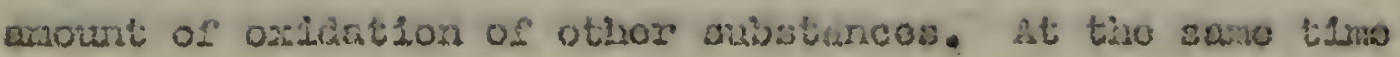

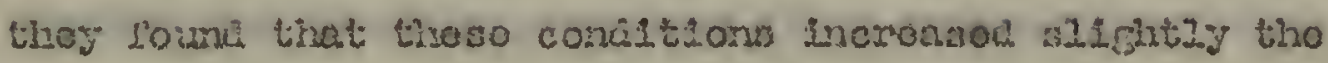

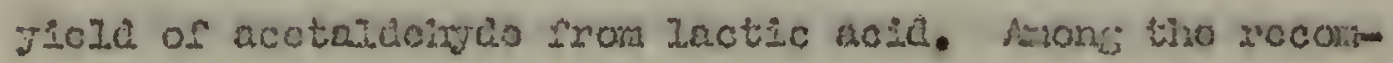
nondations whäcis woro nacio Lir and attompt to bring about a roluction of the potontiar aro, riret, roluction of fiso con-

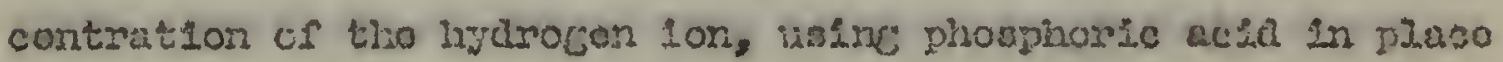

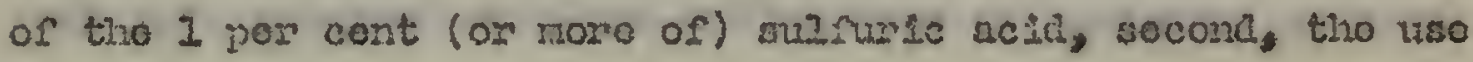
of larger sucunta of manganous sulfte than had boon usco proviously, and, tilnd, the wso or mangancse dioxleio in placo of potaselum permaneanato as an oxiliant.

Tho etatomont 18 mato by those authors tirat "at tho presont tino thoro is ro satisfactory procolure which will

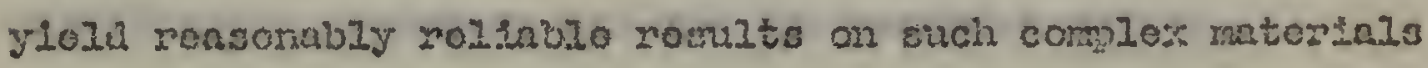
as culturo modia or urino." ghoy Juntiry tho uno of the Ir

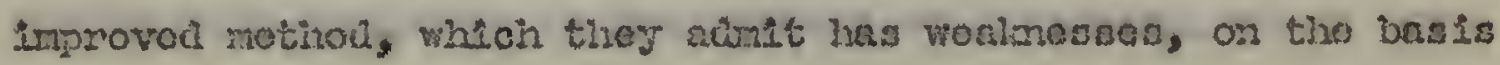
of tho fact she, nItiourit tho monsurenents are not aboluto, thoy aro constant, and as a rosut of this constency, chancos In lactio acil contont cun bo accurntoly dotominod. In this roproct tiro rotisol is valuable. It $1 \mathrm{~s}$ tho telier of tiro propent writor that tho statonent of the authors, wisch is quotal abovo, is an underostinatian of tino tmuo veluo of their oum ratrod.

The last roport on the serlos of studios by Friecionarn appoared in 1932 undow tiso authorship of Friodonann aru crncser (32). Whey foum that tho pozimity to pathologicn I laburetories, In which formaldolyzdo and acotone were boinc used,

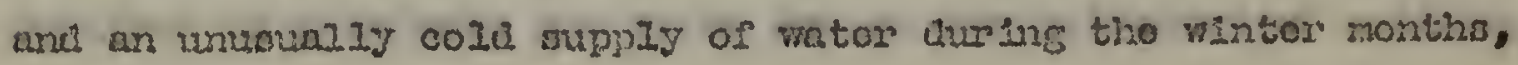




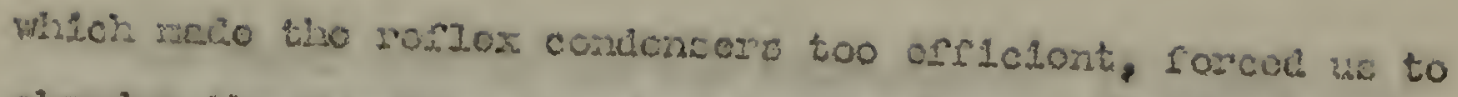
abarion tho aration procodure first recorronded." (20) To overcomo tivoso roro rocomt difficultes tiros subutititon

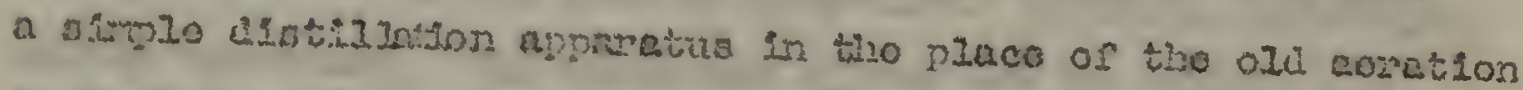

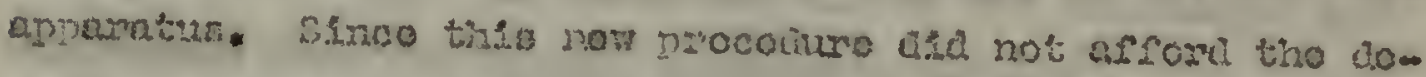

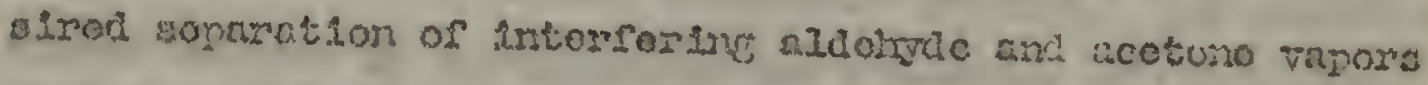
that were obtairad with the rerler tyjo of condensor as usod

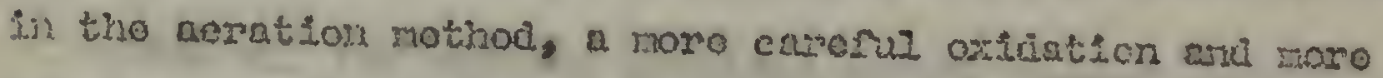
comyloto end controllod prelininary troatmont was rocessary In orwer to obtain gool rowults. Arter a cararul invostigation of tho moner comlitions, the autiane roportos that there vaa

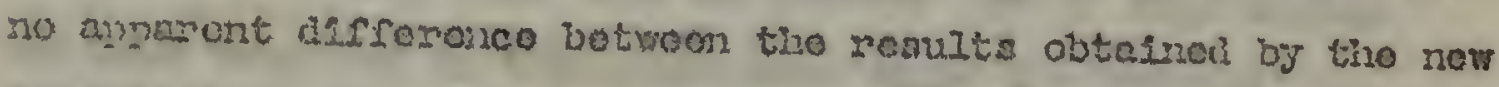
dictillation pracociure axd tiro olu aeration rathod.

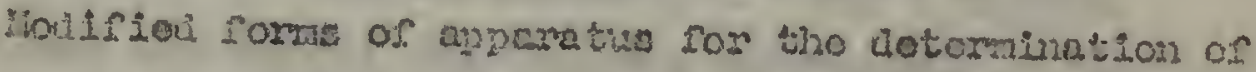

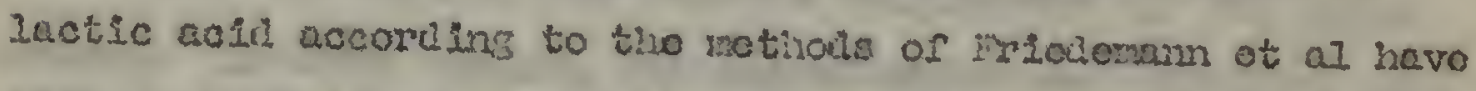

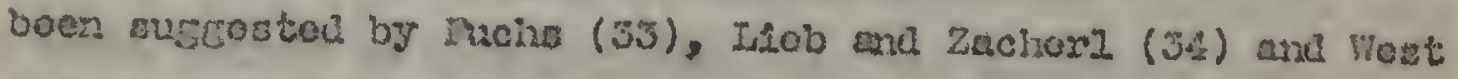

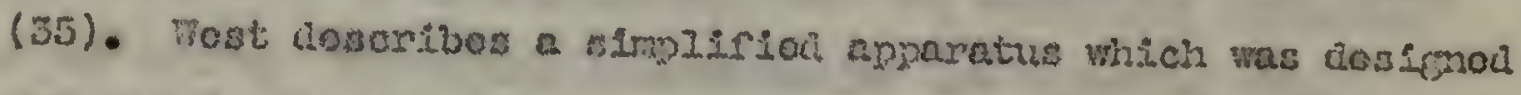
for uso in the noration jroceduro and willch se arallablo for

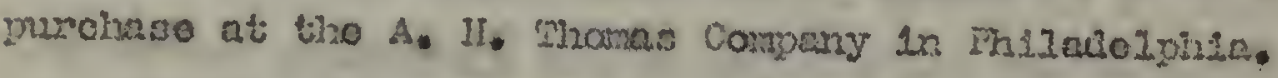

For tho doteindnetion of Iact1c acld In blood hrollerFarcinen (36) used an axidation to acotaldoldyle sirilar to that dencribod by Fricatian (20), but moasurod tho bound bisulfito

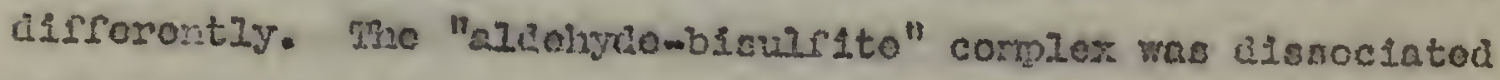

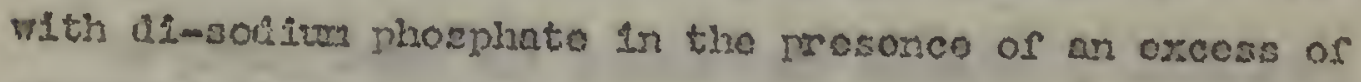
standard Lodin, and tho unusod fod In was monaurad with standard

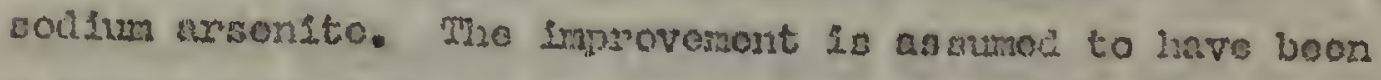

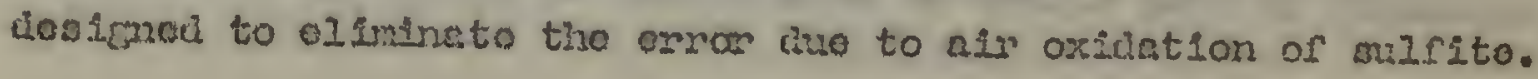




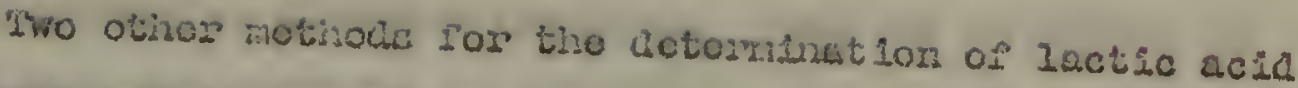

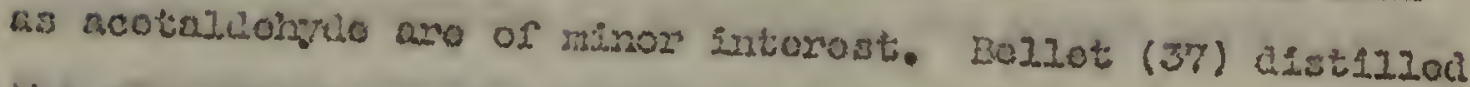

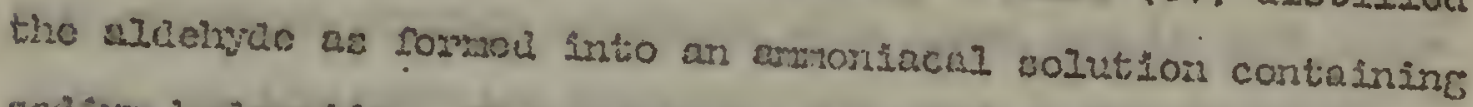

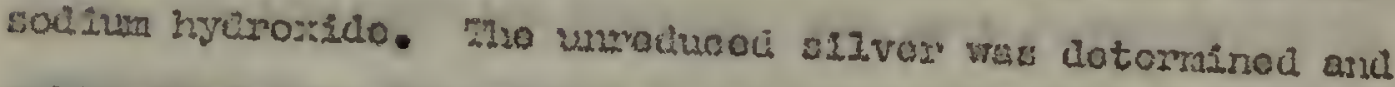
subtractol from the amount orikinaliy preasont. Tho anount of

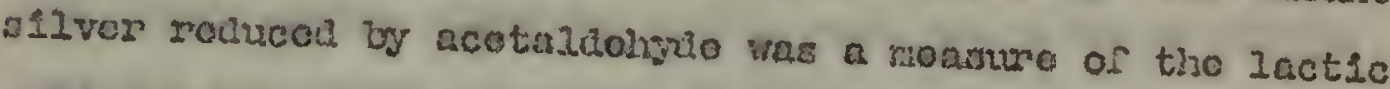
acid provent.

Nith aIl tho rothois existing at tho prosont writing, It scoms undow 2 rablo to attempt tho we of ouch an uratablo aubstarce ao curonincal alvor for the dotornination of acotalcolydo. Tho fuct that no rurtinar uso of tilis latiod Las beon daported in tiso I1terature sinco tho orispinal is sucestive of the lmpacticability of such a mothod.

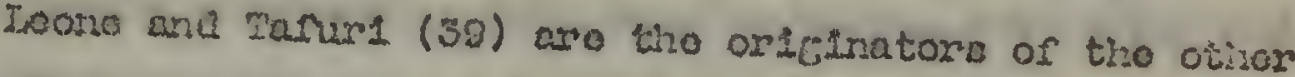

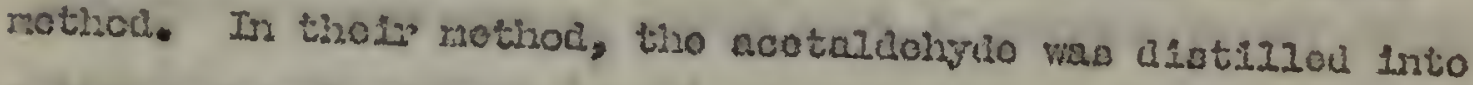

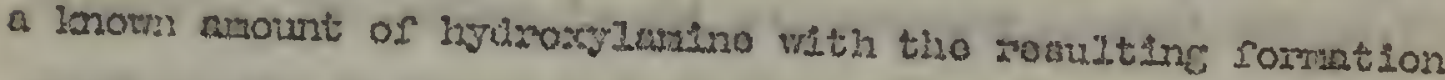
of an oxino. Tho axcoso herroxylantuo was titrated vith

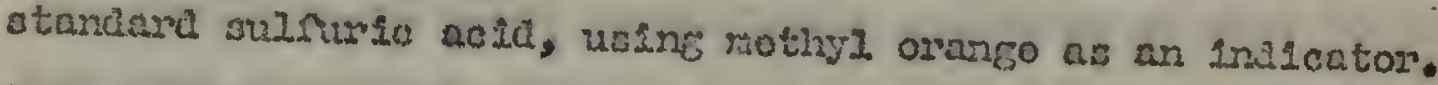
This mothod apparanty has no valuo sinco 1 ts rocurronco in tho 21 terature has not boon observol.

\section{Oxtersitor of Iactic Auld to Oralic Acld by Rormancinato ir nimine Colution}

In 1012, Eacos and Dunbar (50) reportod a nuccossrul dotomination of Iactic coid in tonato prolucts, baned on tho quantitat1vo cxilation or lactle ucia to arnlic acid by potrosium 


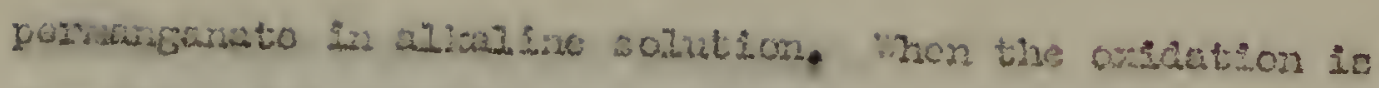

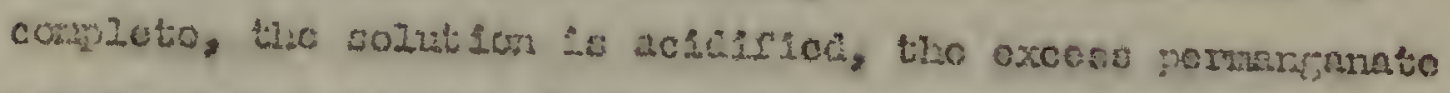

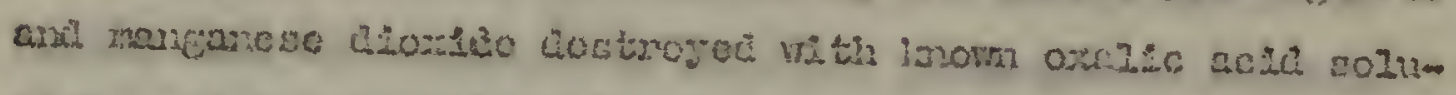

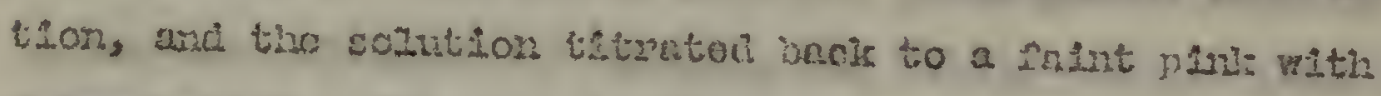

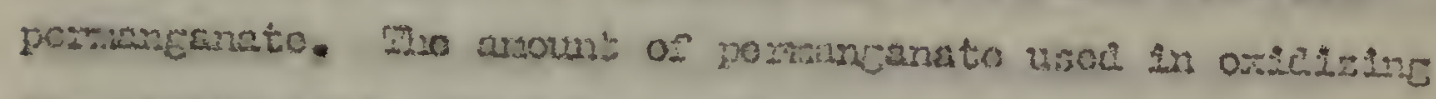

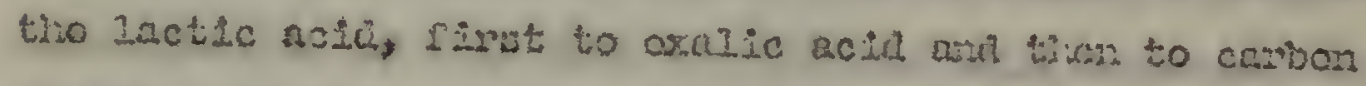

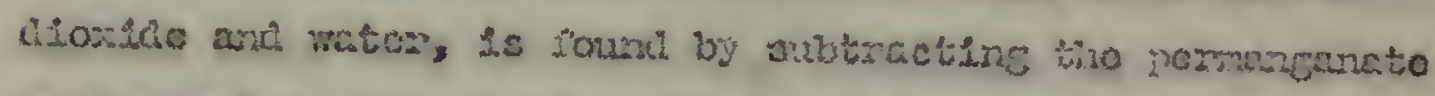

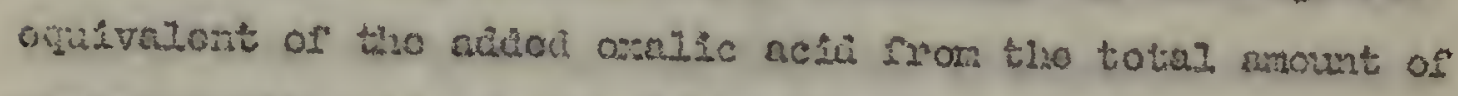

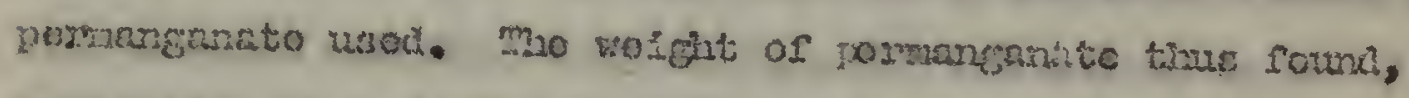

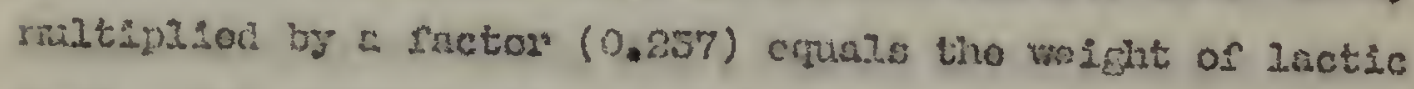

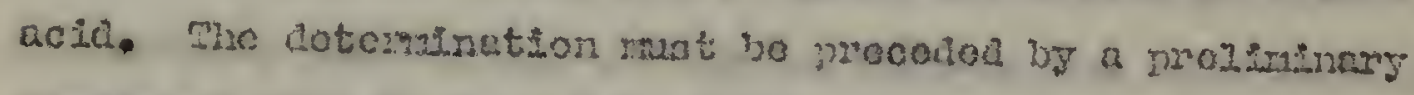

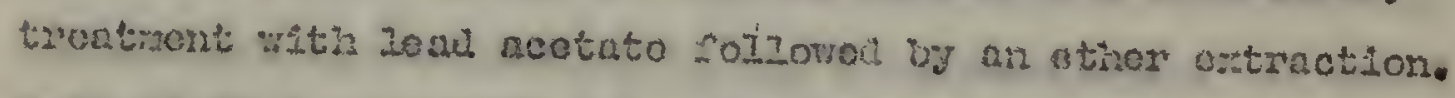

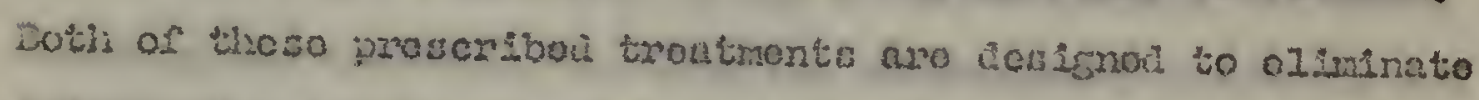
intorforing substusecs, but, dosplto twone, noth renzio ara

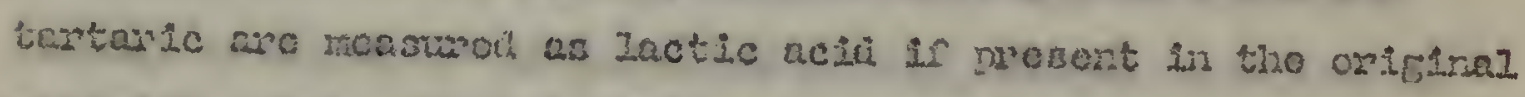
matorial. Whe mothou 12 ola and probably te replacol at tho

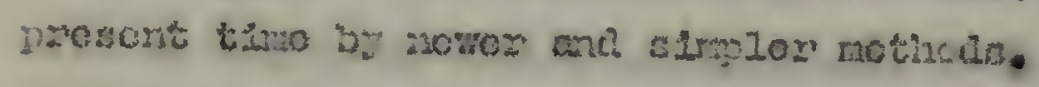

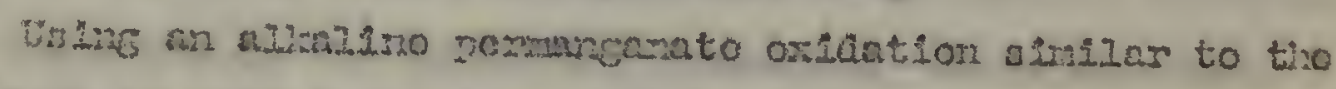
ora just doscrebod, Onclors $(10)$ in 1017 coteralined tro lactic

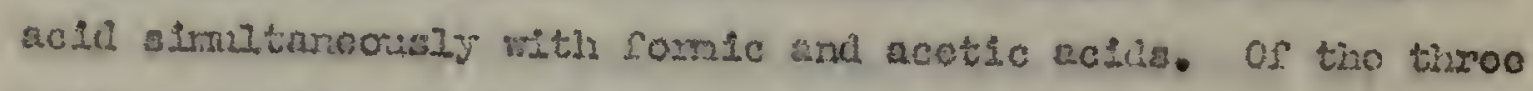
aclds, Inctic ache is the onit one to form aralle acle by this oxidation. The oxtic acil nociucol is wopernto ns tho calcium salt arf so dotedrinod in tho urual monnor with por-

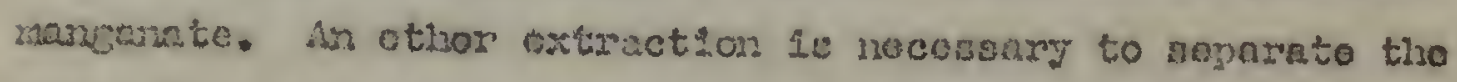

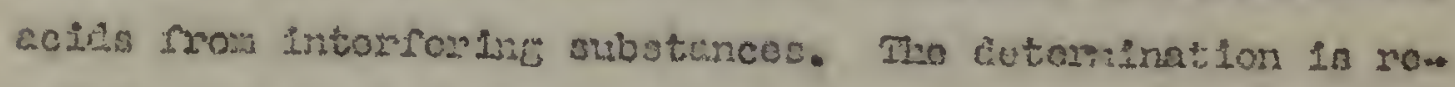

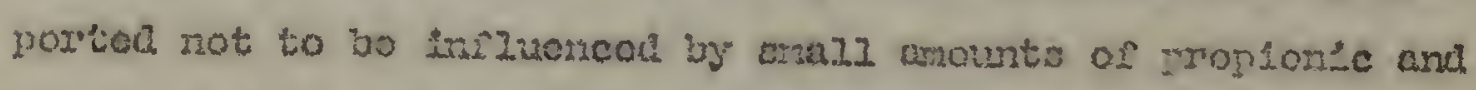
butyzic aclia, wut tho oxtont of kntorferenco of onibr ether- 
solublo oubstancos is not montioneh.

Anotiver spociste applantion of the lotematution of Inotic acid by oxidrtion in alikino permanganato colution

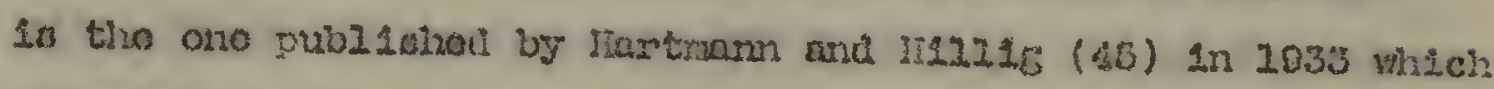

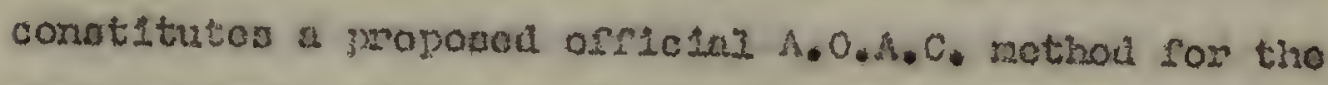

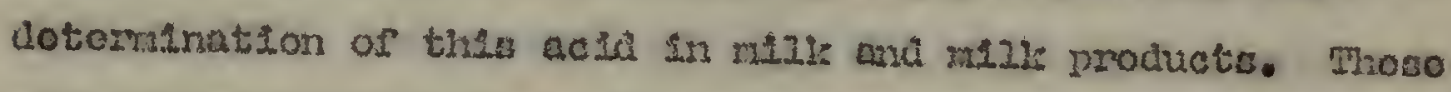

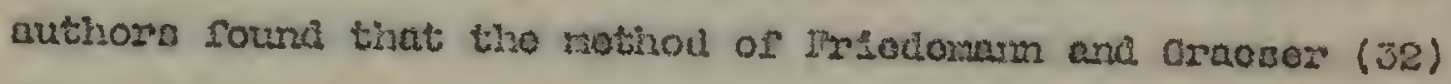
(Ingeo 17) is too oracting and that tho succoesful lotorminatwon coponda upon too snay factora for the mothod to bo nocomondod as orflcial. ha a rosult of this invoptirgation

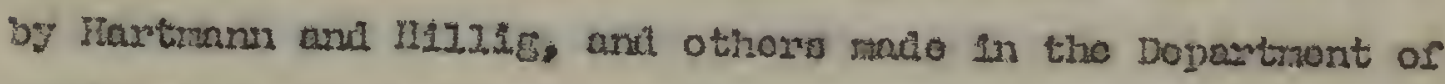

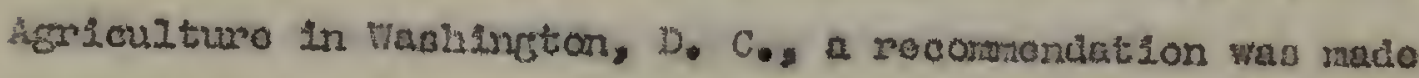

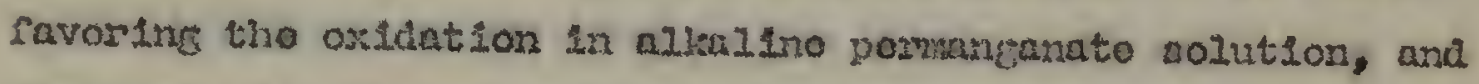
dotarutuation of tho oxnl10 acid formod. Mho inconsistont

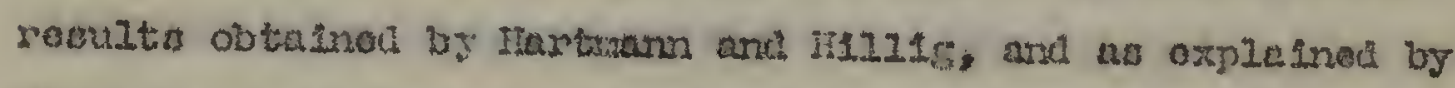
thosn, may have bean whe olthar to the mbsorption or lactic acla in tho heary casoln procipltate, or to cortain asfraculLios Inireront in the oxidation proceluro. Sinco the vame

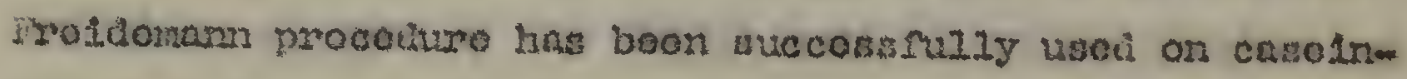
rroc aubstances by the provont wistos and othors $(30,32$, and 35) It aopas probablo that the poor rosulto mut havo boen causod in this particuiar caso by the Inclision of lactic acia in the casoun procipitato. 


\section{Osidatson bro Dicirrorate to Acotso scia}

Bocause ho was not ablo to obtaln rellable rosults with elthos tho gravinotric motisod of runt (C) os the oxidation to oxalic acia accoralus to a mothod similan to that of onodora (40), ssoboronys (42), In 1017, or16inatod a notiod for the dotorrination of Inctic ncla in wino bneod on tho oxidetion of Inctic acta by notass Lum dichromate in moiorately atrong oulruplc ncli solution undor a rerlux condonsor. The nootic acld fomed is later astij.Iod and titratod wh Btandard alkral in tino ueunl mannot Ono molo of lactic acto Ylolas ono rale of acotic ac 10 so that tho acidity of tho acotic acid distillate La tho saro as tho lactic acla contont of tho

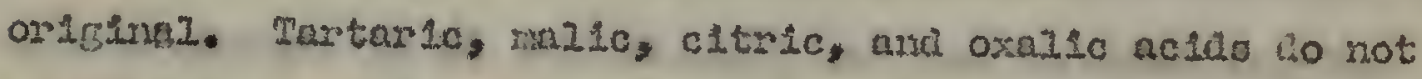
sntosicore since tiroy wro axidincu dirocty to carbon dioxido. Ilowover, volatile actds, alcoliol, acctono, and cortain ostari mast bo provioualy rozovod by stoar distizlation. Moro is a nogativo arror of about 3 por cont duo to the coxploto oxldation of cono of tho inctic acta to carbon dioxido and wator.

Mo clain is mado by Szoborongt (4I) In comoction with the diclunomato dotomination that lactic acid may bo loat by ontraidrant: in tho distiling vapors. In an unmublicisod pepor Anuerson (4R) whove that approciablo quantitios of lactic aold are not lost durine a roasonably long poriod of simple alstiliation undor oltior rolucen ar nomal proseuroe. Theso distillations, howovor, were not tho tetean alstillations as prosoribed in tho

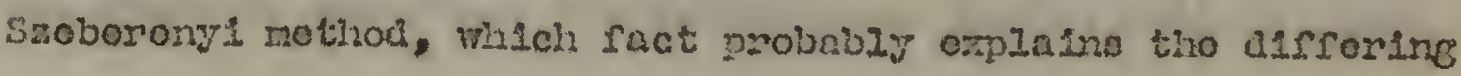


conczursons.

In 1010, Schuppas (65), contruming the ronle of

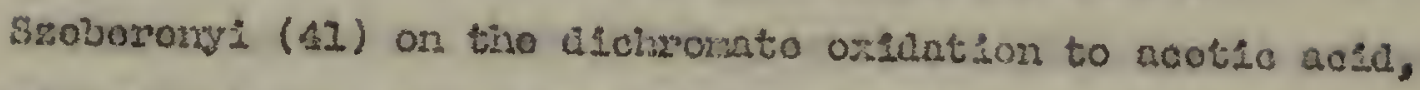
found that tho ratizod war faping sccurato on nolutiona contalning tortarlc, andic, auccinic, nni cltric acids, but doportad that the mothod was unatiafractory for tive dotornination of Inctio acid in winos, since the romulto woro too hifer

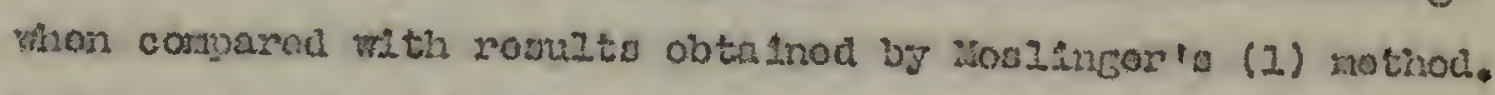
Sucroso vas shows to intorforo if prosent in tho aolution. ใuzirge oxtatasion.

In contrast to tho fallure of schupll1 to ralso succese-

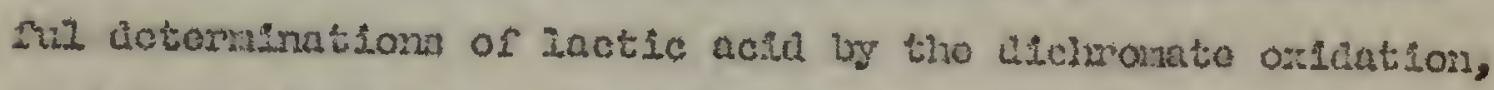

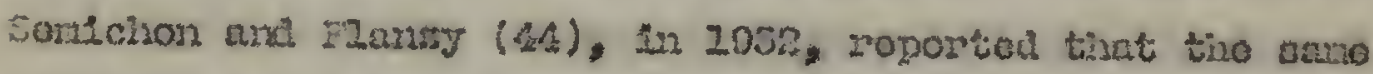
nothol a!noaro to bo sathsfactory for uno in roanuing tho

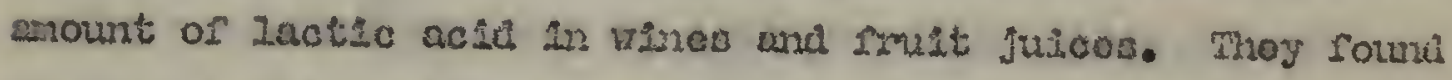
that no lactic geja wa ontralnoa in the volatilo actas

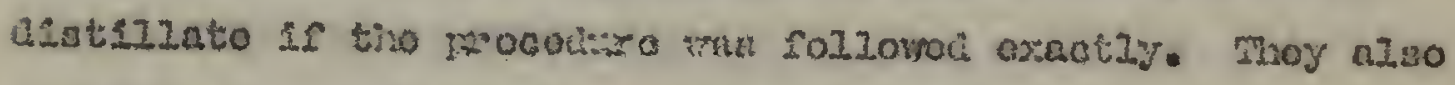
foum that pyzuvic acie and infinor fatty acilo wore oxtulaod to acotic acti.

\section{Ce Gasopotric Mathod}

In the oxidation of lactic aciu by pormanganato in nela solution, thore ronults ono molo of cnitron dioxide as woll as one nolo of ncetaldohyle nes molo of lnotle acla. Uolng a pioIininary trostront and aubsoquont oxthation simisar to tiut of Prlodenam, Cotonlo, ma scharcor (20) (rago 25), two othos workers, Avcry and linstings $(46), 2 n 1031$, found that a unonul but bornovinat onpirical dotominution of lactic acid In ulool 
coura bo mado by woasurine tho arount of carbon dioxiae, ration than the exount of a Idohyde produced durins the courso of the oxidation. Sinco tholr rosults on blood voro oomowhet hifior than thoso obtalnod by tho rothod of Irfodomam, Cotonio, and scharfor (29), whlch mothod hnd becn chom to bo anocir1c row lactic acia by comparison vith otion methads, It vas concluale the como subotanco prosont in blood was producing tranly but alenificant quentitios of carbon dsor:ido. The anownt of thida cas soenod to bo constant so timet whon the propor comoction factor was apol lod to tho calculation of rosulte, tho resulta noro comparablo to thoso obtcinod by otiner mothods.

It is rocalied to nhal ct thin polnt that clauson (10), In 1022, asscouragod tho uno of a gasomotric nothod, dotominine cribor monaxilio produced by a 50 per cent sulrum acto orilation, bocaurs of the falluro of auch a reasurenont to bo spectric for Inctic acta.

\section{Colorirotzectothods}

Diore appoars in tho Iltornturo a series of qualitativo toota for the dotection of lactic acld Liz satalz quantitiog, particularly ror lactio acid in blool, tLssue, and othor blolorical metcrals, basel on tho color dovolopod by Inctic acta or Its decorposition proulucte in tho prosonco of cortain opociric color roagonts. Sinco, for tho most part, tivo nothols aro only chualetativo, no raso than montion of thon will bo attonitod In this papor. If tho addition of hals $a$ urop of a 2 per cont 


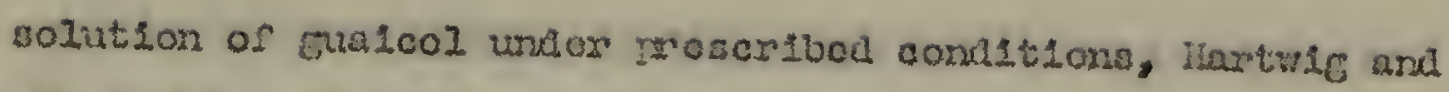
Saar (47) conla dotoct tho prosonce of Jactic acid in concontration of 0.2 nor cont and loas by the forrtation of a charactoristic rod color. Faron (10) usod thiophene for the dovolopront of a red color in tho pronenco of ncetaldohydo romod from lactic acta. Braucr (10) usch ronorchnol, and IJicort (50) used pgrocatuchol in tosts susilias to that of Fonron (45). Inctic acil wo dotoctou by corratir (51) in concontrations rom 0.5 to $1.5 \mathrm{pcr}$ cont by the aluition of 15 por cont potrociul thiocyanato solution. Tho orango or jurpliah color devoloned by this roagont in tho probonco or Inctic acid

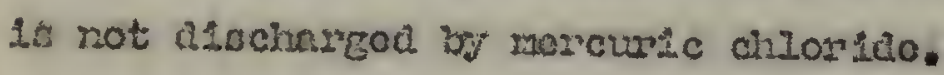

Woncel and coldecholdor (52) roport a cuantitativo colorinotric nothod uring voratrolo. Thoso authors ostablishol tho ract that tho amount of color doveloped with this roogent Ia proportionnl to tho amount of lnotlo acid present, and on this basid, thoy made accurate comparieons with known standard solutions of'Inctic acid, and thus proposod a quantitativo mothou for tho dotormination of lactic acid in 1 c.c. of blood.

\section{I4sscollemoous ilothods}

Convincol tint tho oxisting mothodo for tho dotormination or lactic acia worc not eureclantiz spocirle ros tho ncil, molpe and Farner (53), in 1017, attomptod a moro comploto woparation or Inctic acla rrou othor ormanic actua. In the course

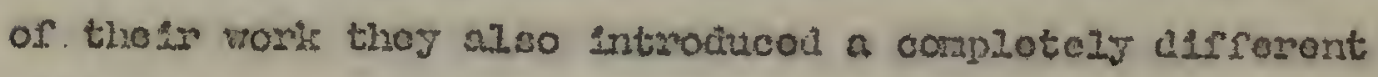
Litinato nonzure of Iactic acid. Tio soparntion from formic, acotic, citric, and tartario acids mas mato by means of a 
fractional alstillation of tho etryl cstcrs of thoze actas

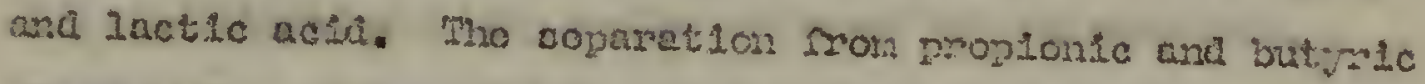
vas bacod on lrigolutility of the quinine salte of propionic ard butgle in carion tecrachlontie. Lactic acid vas volighol as ainine Inctute fozlovine tho oveporation of tho

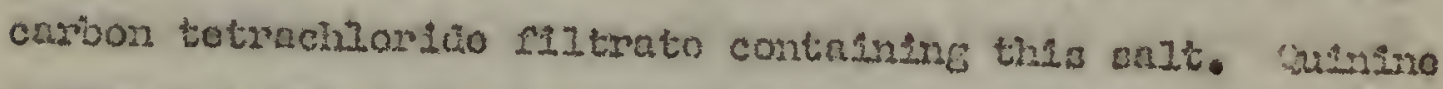

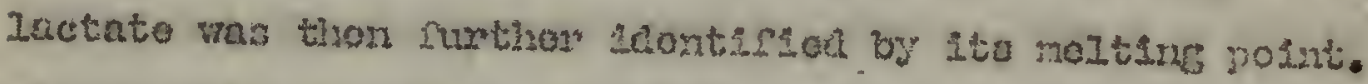
2120 sodults sopontod raxiou frox 90.7 to $10 \%, 0$ per cont of

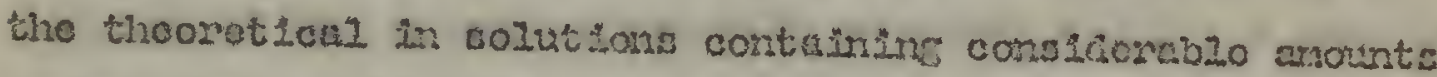
of the othor acicis nirodur zontLonod.

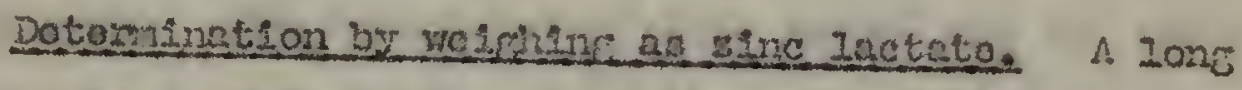
whi involven mothod for tho cotomination of lactic nold 15 tissue or slood has beon leacribed by fiolf (54) in 1924. protolns aro romovad by ono of tho unual protoun prociptcarta; tho filtrato ia craporated to a convorilons voluro and oxtracted

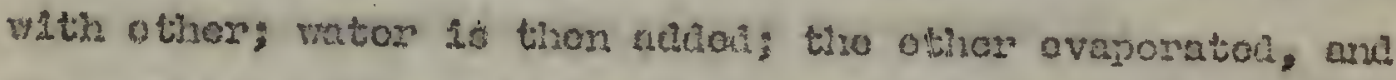
tho solution riltorad. Mro filtrato is treatod with load carbonate at $100^{\circ} \mathrm{C}$ and age In P1ltarad; the load is rowovod

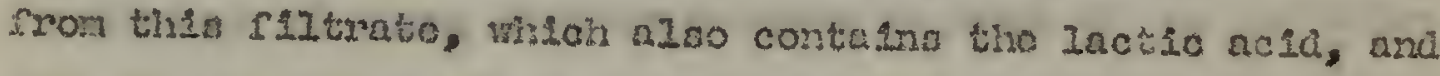
the solution trantol with siric carboneto; "1no lactato ss

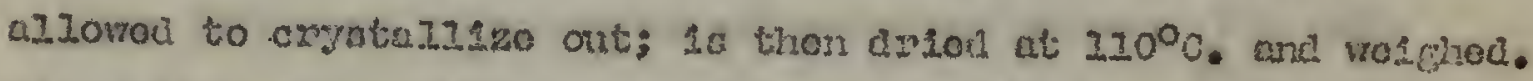

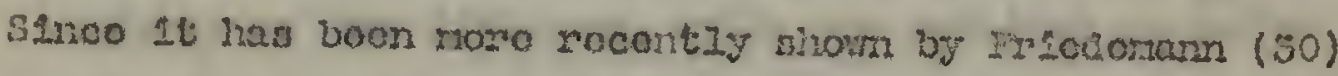

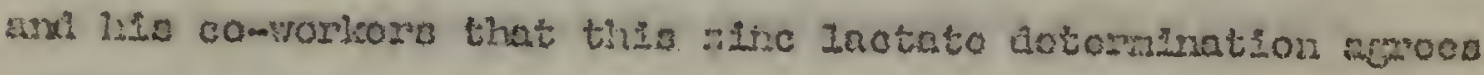
with the acid remmanato oxiantion, end anco tho latter in

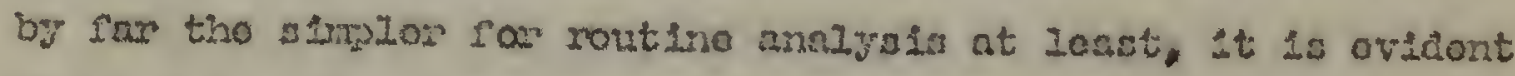
thet euch an involved procoiure as tolr's no lonces has any veluo excont, posolbls, as an occastonal chock on como othor motlion. 


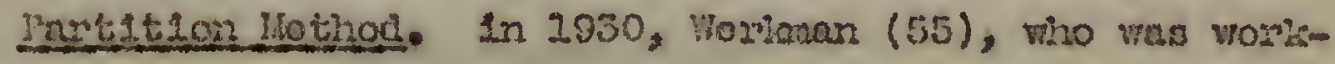
ing on a aturatod facty acidi producci by fermontation, dovolopod \& methot for tho detomination of lactic and othor

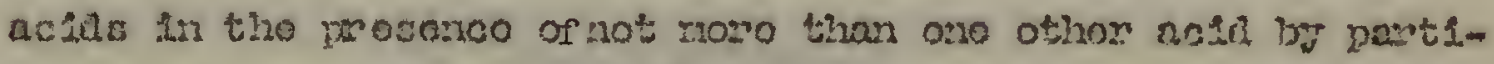
taoning betwoon 1soprongl eticer and wator. Tho wetor solution of two acild is gheivon up witis a efivon amount of 1sopront 1

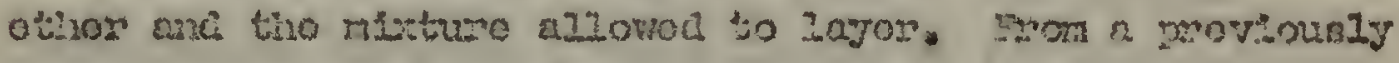

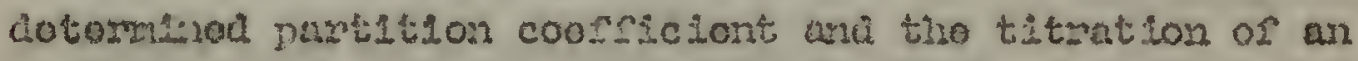
a.I cyut of tho aquoous phaso vith standard a.lkall, a vory coou approsination of tive unound of lactsc of othor acta maty be calculatod. The divartagos or tils sothod are 1ts rapingty and oase of maripulation, as woll as tho fuct that lts uso mats bo extandod to tho determination of any pain of aclds which aro solublo in wator and in 1sopnonyi otwor. Ite clicor Alandvantage is tirat thom cax bo no nomo than two acids prom aent if the lotormanation is to bo vinceotidus.

In an attompt to looson the sovority of this 1 imitation, tho wano worlar (50) hns oxtoncial the cotominatson to include a mirture of throe difforent acide lustod of two as beforo.

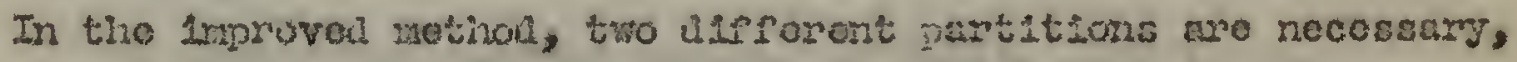
120 ind Lifferent moportlons or wator and othar. 2he porcontrgos of tho dirforont acids aro ottained an boforo by titritine an aliruot of tho anuocus phaso wth standard alknz.. 


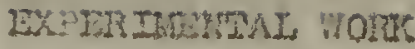

\section{A. Coneral}

\section{Cholco of yethod}

It was part of the orfinal flea of tho presont invoutifcation to apply a ienown mothol to the detomination of lactic acid in ar unlawom piclelo bsino. A flanoe at tho 12toraturo convinces ono that a lareo ancunt of worlis has boon dono up to the prosont timo on the determination of lact10 acid in a muluen of widozy variod typos of nateriaja. No rertion has boon obsorvod, howover, of the nowsuronont of

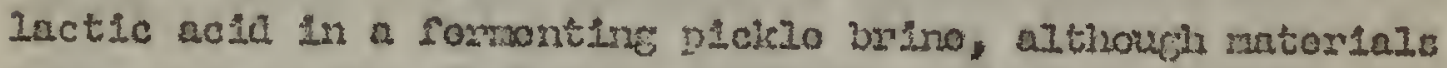
which alioula approach this Bubstanco in conposition are culturo modia, inturaly fomontod mano, frust juscos, axd

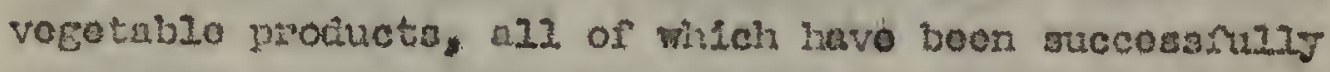
analyzod for lactic ncld according to various mothods which appoar in tho Istoratruro and whoh have boon roviowod in this papor.

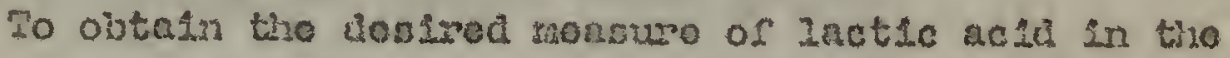
unimown solution, thorofore, it was nocousary to chooso from unone the oxistine mothods and aply tho tochnigue of the rothod choson to the detomination of the lactic acid in the ratorial at hand.

Mio nethola Envolving tho 1solation of IActic acid an barium lactatio aro lnown to bo Ione and todsous, and at best civo rooulta that aro only eproxinately corroct. Darlum 
Iuctato nothous, thoroforo, ald not aproar to bo tho bent

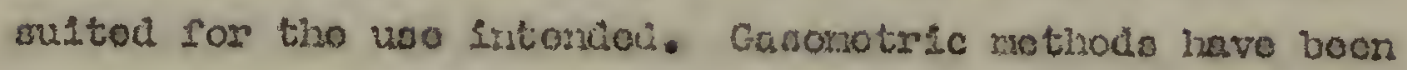
criticizod as not bolng opectric and tiso woo of colontratric rethods applion chlory to tho detormination of vory mazl quantitios of Inetic achi woro othor mothodo fall to Give ar accurato monmuromont, so that thoso two posalisiltica roro olininatod. Tho notiod of thelpo and Falmor (53) which was dosignod to be hichly epociflc for lactse acid has ite ches advantago in Ite pocifloity, but roquires tho asfricult otop involving a vapormphase convorsion of all tho acids prosent to tho othyl catorn. Mts and othor afflcult oporations rondor the rathod Impracticablo. Wortonants (SG) pantition nothod io vory usoful for tho analysis of cortaln culture modia for wisich uso it was orifinaliy intendod, out it is ingtod to tho lotomination or Iactic ncid in tho prosence of no noro than ono or two othor acids. Itwitizomoro, thoso othor acils and tho is partition coofficionts mut bo lnown. Thoro is aiso tho ndial possiblity of a variable pritition coofriciont in the prononco of the laxeo axiounta of salt found in brinos which havo boon ana Izad dusirc tho prosont invostigation.

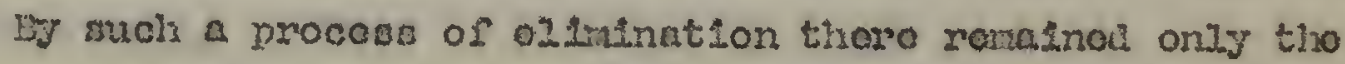

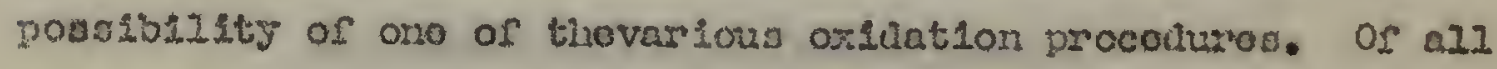
the lanow axlatation motizods, tho permanganato nothod loveloned by Irledorsan and othors (32) appoared to be tho most 111:017 to civo tile boot remulto for tho rollowing reasonge Firet, Wido variations In amounte of Jactic acid can be dotomined, the authore reporting succosanul dotorminationa in colutions contininiac 
from $0.045 \mathrm{me}$. to $200 \mathrm{me}$. of lactic acle witis an nocuracy of or to 33 por cent or the thoorotical; second, cormloto information as to the coureos of omor and tho posalbility of thoir oliniration; Finir, comparativo simplicity and adaptability to routino analyess; Fourtl, wato variabion in tho typos of matorial that can bo analyzod.

Keoping in rand that the coterminction of the hydroger Lon is not a specirlc dotormination for lactic acie in a romont where other actas rany also bo precont, oxo mist rocliso that the dotomination of Iactic acla deponis on come chomical reaction that sis opcoirle for the Inctato racical. For this

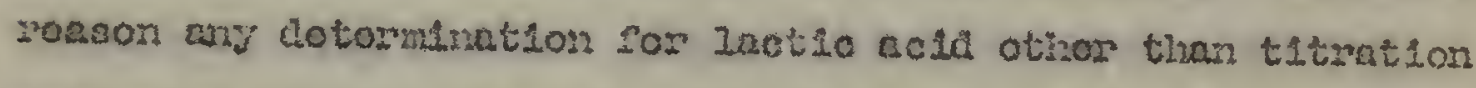

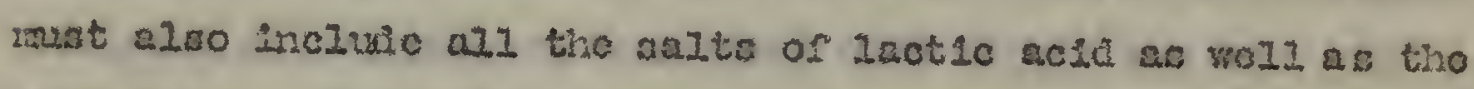

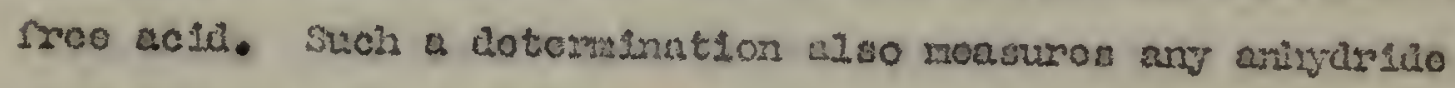

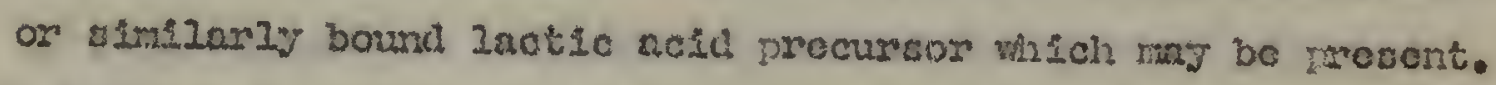

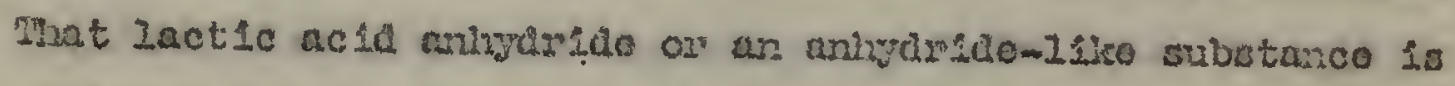
prosont in aliuto lactic acld uli be show in a subsochent part of tisis papor. The torm Inctic aclo, thor, won rontionod In the futuro in comection vith ito dotornination by oxilation,

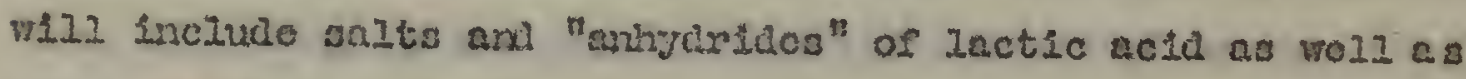
tho froo actu.

\section{.2. Dozcription of lochod Choson}

Sinec tho mothod usod in tiro irosent invost Ifation vas ossentialyy tho samo as that toscribod in detall by lriodomann and ing comorkors (32) It vill not bo nocossary to frcludo moro thima a bries account of tho atops involval in the procoduro. Tho dotalls aro anittoc. A mocmurol anount of tiso uninow solution 


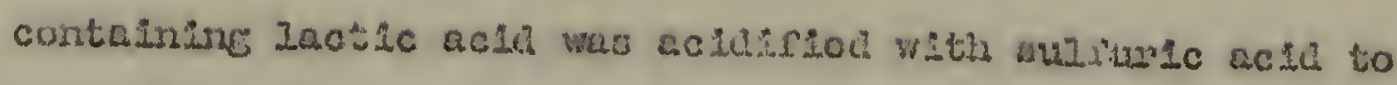
provont spoliago by bacterial cocompostion, and at tiso tivo of analysis an aliquot on tho aciolfia samp was troatod with

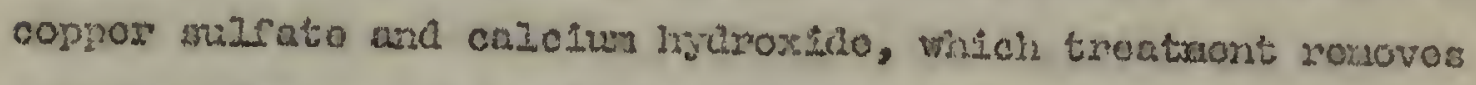

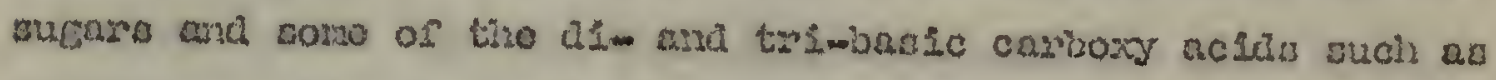

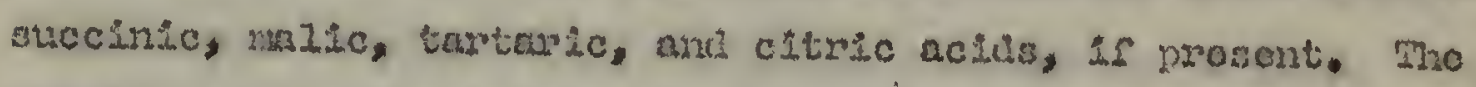
solution, thms troatod, tras malo up so voluno and contrirugod to timow lown tho pracipltate forma iy tio calchum indraxido and

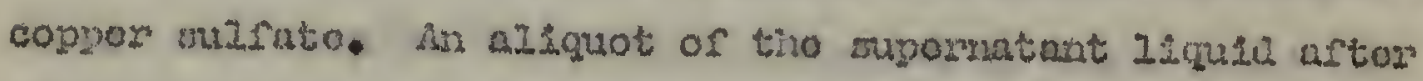

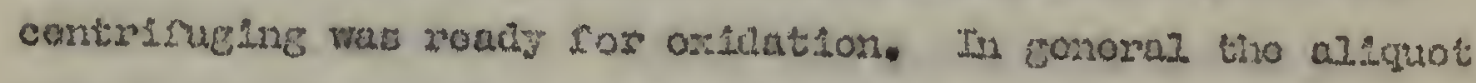

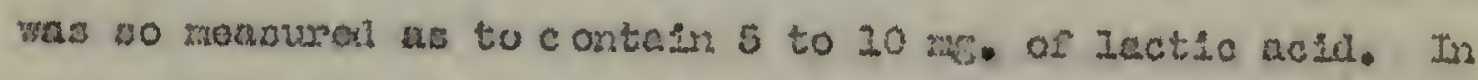
cados whoro tho atanday lactio acta colution was uwed for anolyglo no prolininary troatmont w1ti coppor ard $11 \mathrm{mo}$ was nocosenary. Tho lactic acti in tho propared samplo wa oxiulroa by pomareanato at bollins tormoraturo to acotalcanglo in a solution that contatnon approzinato 150.037 molns phospisoric

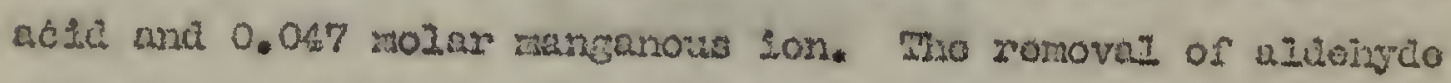
vaporn was offectod by moans or tho aeration procociuro as

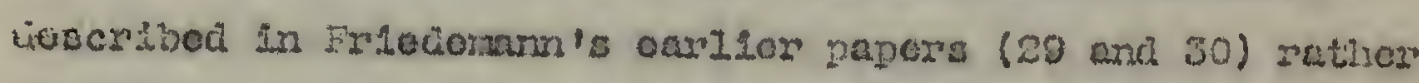
than accorainc to tho sinmlo aistiliction mothou as rocomanciod In a. zator papor (32). mo Inttor Cistizatson mothod was triod but was found to etvo anconeletont romults. In olthor coso tho

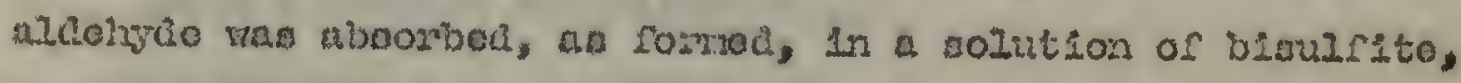
and tho rowutine volution of bioulfito contrining the bound

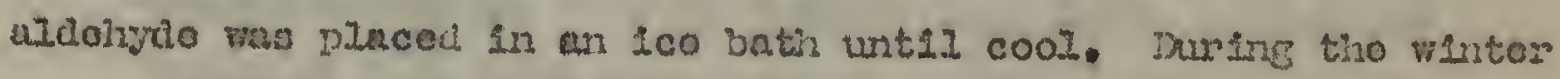

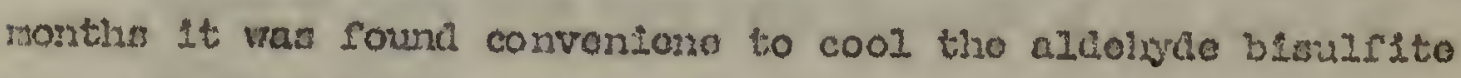
colution by olming placknc tho absorbine voasol containdus the solution on a lodso outeido tho window for a fow nimutes. 


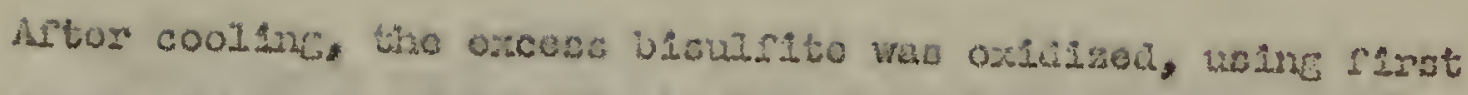

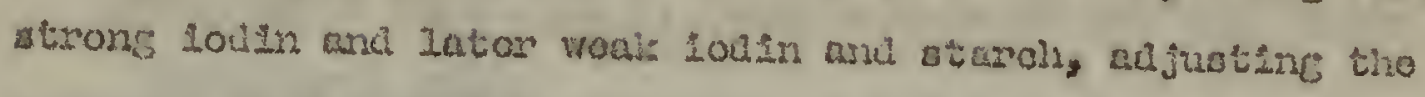

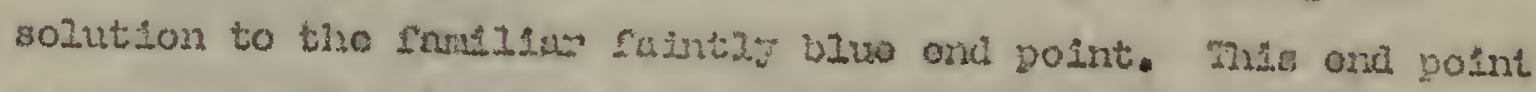
Ls the so-cajzol "first ond point." M130 golution vas thon

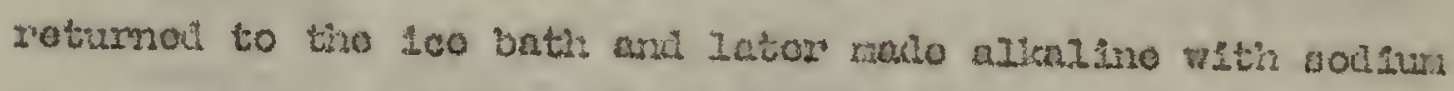

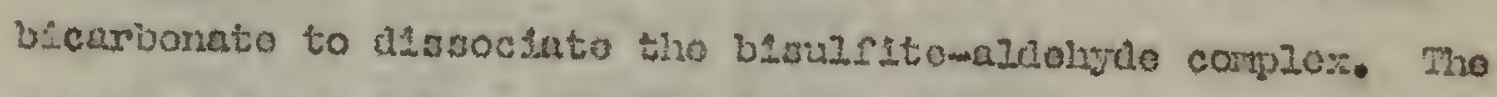

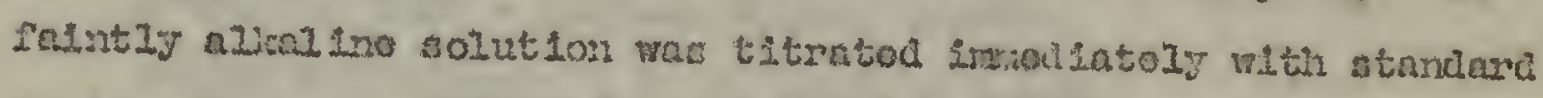
Lodir solution. Mronumor of cuble continotory of 0.0111

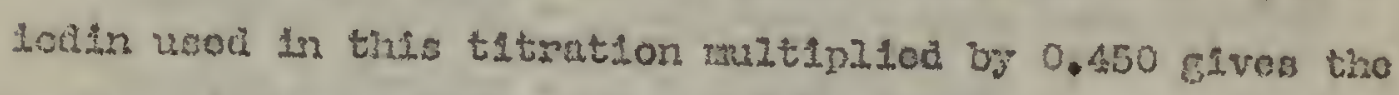
nubor of milligrarg of Iactic acid prosent in tho sarmic. Fino standard lodlu wat proparol for uso, as noodai oach day, from a starider bolution of 0.111 potarsium vi-loviato as recomonded by

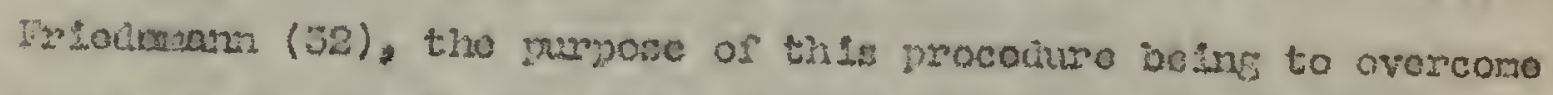

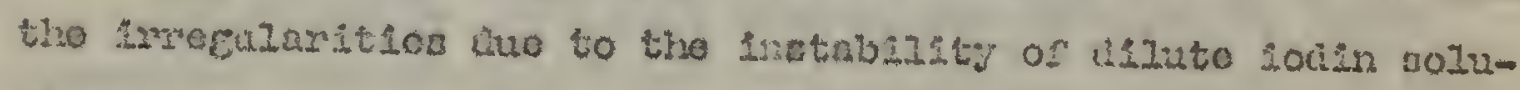
t2ons.

\section{Intortals Usod}

A briof doscription of the instrozinge usod follows.

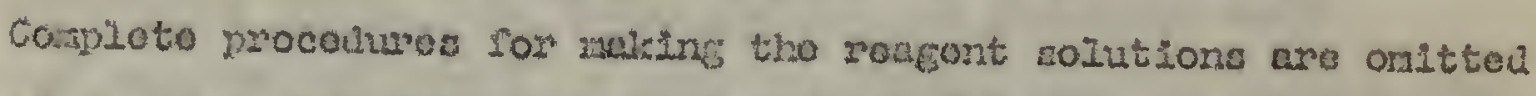

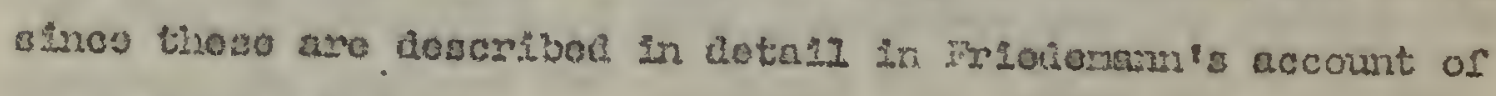
tho ractiou (31).

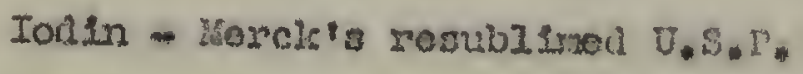

Lactsa ac1d - J. T. Dairor's U. S.

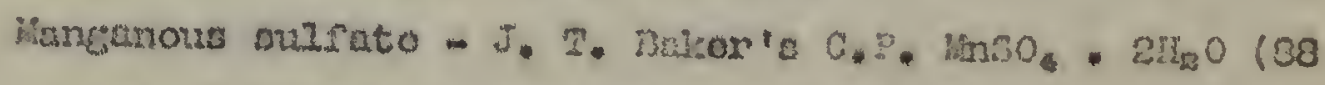
grovas of this salt woro used in place of 100 cramo of $\mathrm{InSO}_{4} \cdot 4 \mathrm{H}_{2} \mathrm{O}$
} 


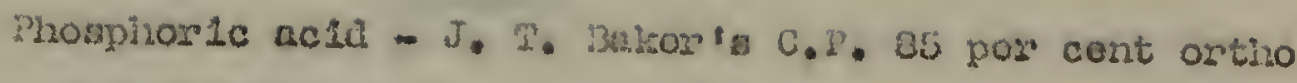
piospinoric acta.

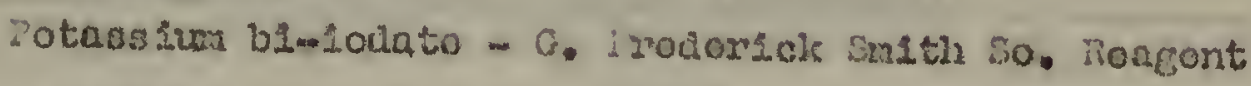
Quality.

Potass lum Lod:do - J. 2. Balsorta C.P.

IYoplonic acid - Lantman Kolali Compans.

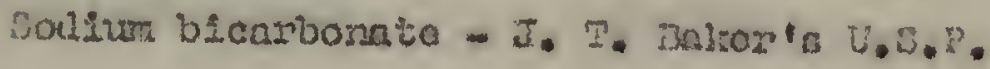

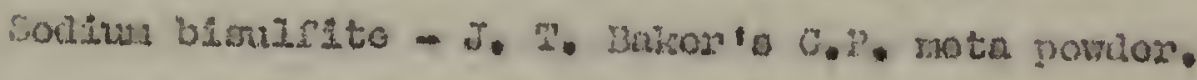

Solliur curoonato - J. J. Daloor!a C.P.

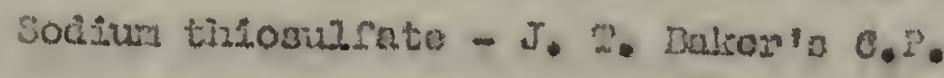

stapoir - J. m. Batron'o potato starch

zine carionato - Baisor and Mlaruson's C.T.

zinc 1actate. Pure mine lachato was obtalnod by timoo

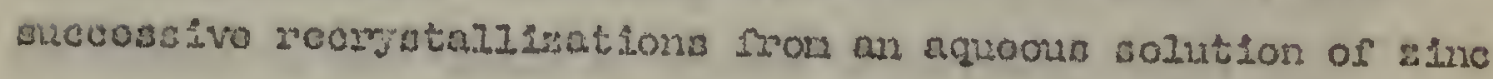
Irctato tixat was obtalnou by varning togotixon 80 groms of Lactic acid and 34 Erans of anc carbonnte. Arter the Iant

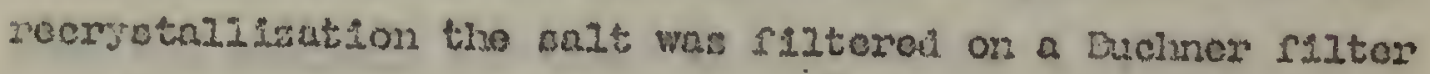

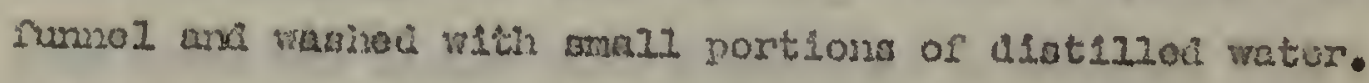
Tho salt was asp-arsod nt roon tonporaturo and tho proiuct thus obtainod wa analjzol for rolsturo, sinc oxide, and "Iactato." Tho anount of "Iactato" was dotorninod by the loos in woicht

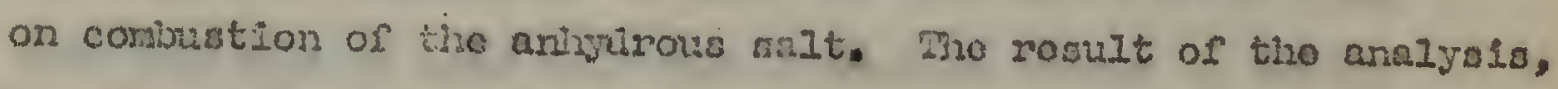

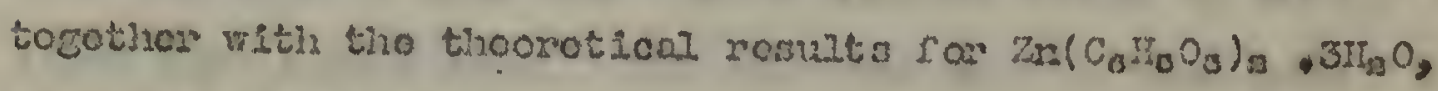
nro civor in Tailo 1. 
TABIE 1

Analys 18 of zine Lactato (Avaracos)

Found

Theorotical

It O (24 hours at $130^{\circ} \mathrm{C}$.

Zno (Vhito Ash)

$10.21 \%$

$18.17 \%$

"Inctato" (By Combustion)

$27.43 \%$

$27.35 \%$

$59.71 \%$

$59.86 \%$

The rosults were sligitly hichor than thoorotical for zinc axido and woro corrospondingly low for "Inctato." This ract would indicate tinat thore was a small anount of hyarolysis of the zine lactato at tho timo of the last rocrystallization. Horeovor, alnc hydroxide, which would be formod as tho result of such a hydrolysis, losos ono moloculo of rator at $125^{\circ} \mathrm{C}$, or $5^{\circ} \mathrm{C}$. bolow the aryine tomperature used in the cetomination, Therorore, the ract that the analysis for wator as woll as tho dotcrination of zinc oxido was highor than thoorotical is ovidenco tisat ane hyaroxide was the contarinant rosponsiule for tho difforing rosult:

Another possibility 16 that tive salt was contayinatod with the salt of sono acil with a smallor number of carbon atoras than lactic acil. That the zine salt of somo acil other than lactic acid nicht havo boon prosent is, hovover, Limpobablo becauso of tho several recryatallizations. To oliminate tho orror fron the presence of aine hjoroxido in the zinc lactate it was nocossary nercly to welgh out tho 
samplo fos tho strulark solution on tho bawlo of tho "Iactate" content of the antersal at Inand mthom then on tho bavia of tho forruza meigint of puro winc jacteto.

It is to bo notod hero that accorasng to tabio 1 , tho crror to bo crrocted from the use of the ingrure strendaral it constlerably lows than tho alfferonce botwoen tho amourt of lactic acid lenom to bo in solution and that found accorlane to tise boet of the rosulta civen in triblos lator on. It apseare, therefore, thet the procaution talon in weiching out the surmie on tho basis or tho "lactate" contont rather than on tho baslo of the rumala wo icht so not necoseary excopt to minirise tiso offect of an accuruzation of a nurabor of errors, mont of which are rogativo.

It may bo nentionoh at this polnt in connaction vitir

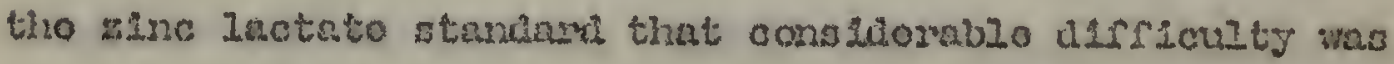
oxpordenooi in provontanc apolzago of tho standand lactato solution rado from tho sine snit. Unloos ppocial procautions aro tainon in rogand to the jropor storaco of tho atandarl aolution in a colk placo, a bactorlal or mola frowith invarlably sots in with a rooulting lose in lactic acia content. Such a dccompositson had boen under way in two dirforont standard solutions boforo tho viltor van avare that audi a decomosition had boon triting pinco. Tho use of thoso docoraposod solution Iel to sovoral sorles of jowulte which, althougin thoy boro lowos than thoy ahoula bo, woro signirlcant

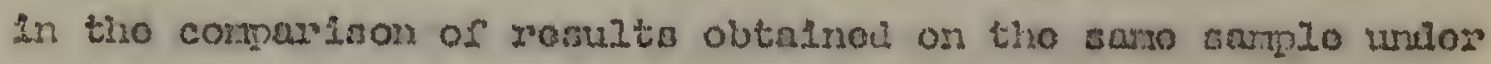

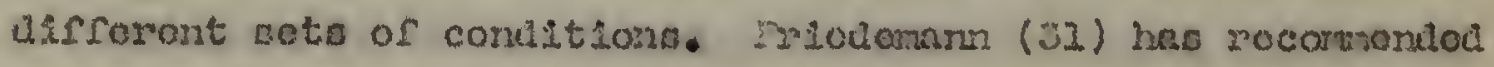

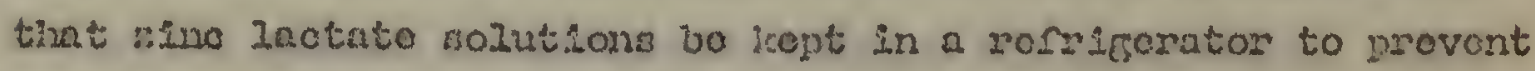
apoling: 


\section{Ampratus}

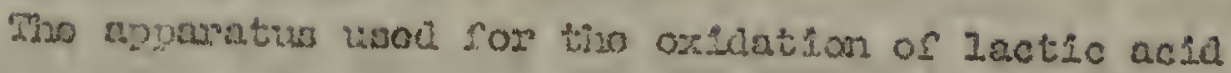
and the ausorntion of allohyde was cosontenlyy tizo sarte as

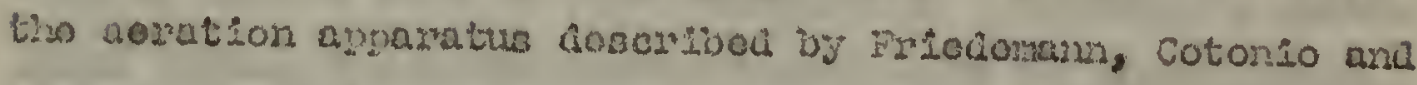

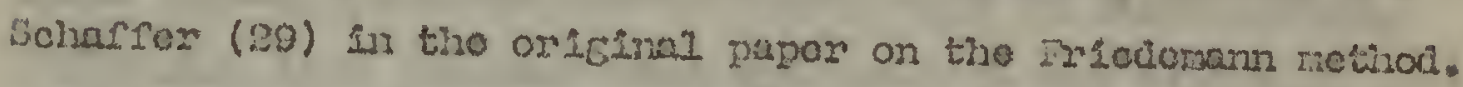

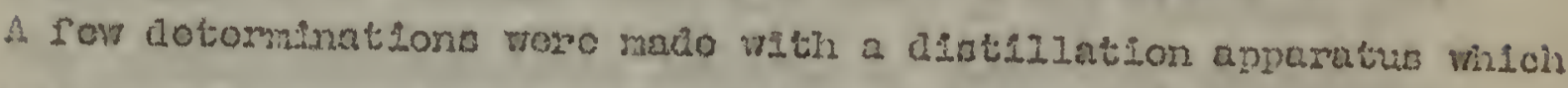

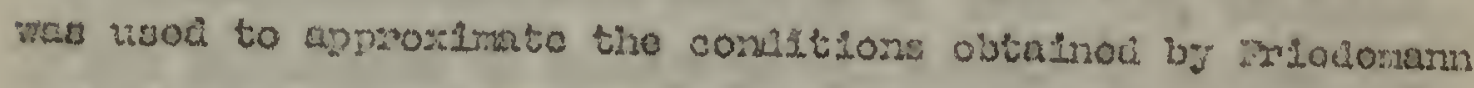

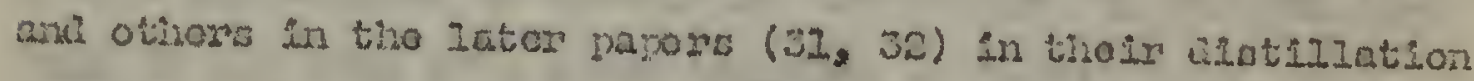

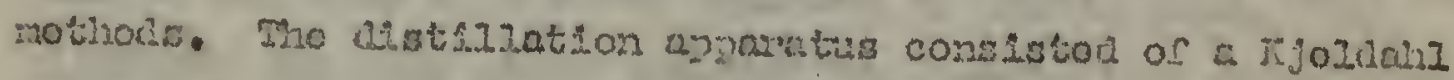

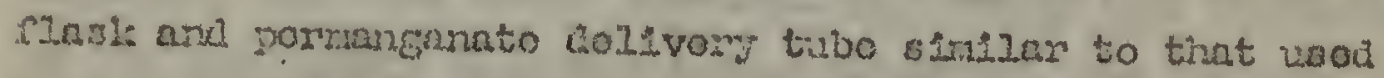
In the aorntion procoluro oxccpt that a ono-hozo atoppos was placol sn tho tirlatio tubo to grovont the aldolyto vapors fros being blown out thougis tho jomanganato dolivory tibo. Por-

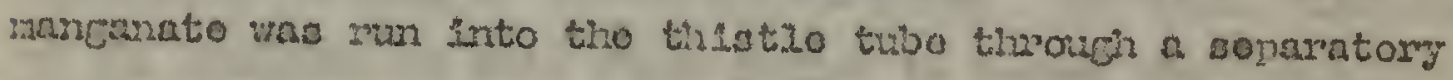

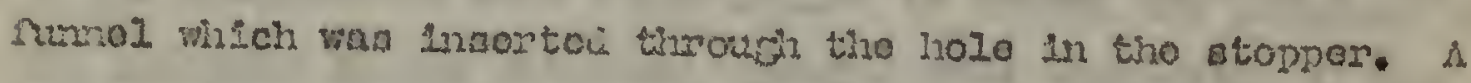

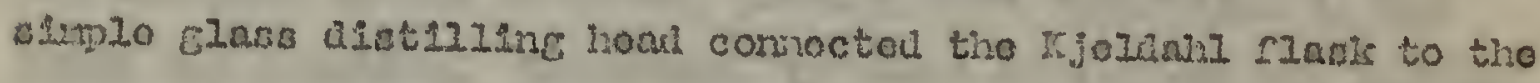
uppos ond of a sralt LLobic-trpo Glass-malod condonson. Tho smanz oul of an oxlshary cugar tube vas connoctod to tho othor ond of the condoncer and bxo Inrgo ond of tho sugar tubo was plecol in a 250 c.c. extraction riass: mich containod bieulrito solut1on. Tho auga: tuko cctou norols as an improvidod dozivory

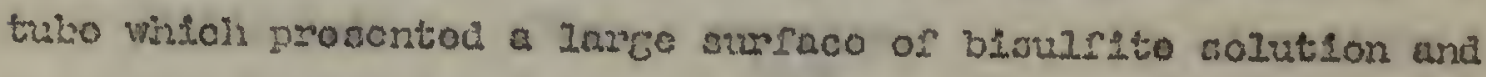

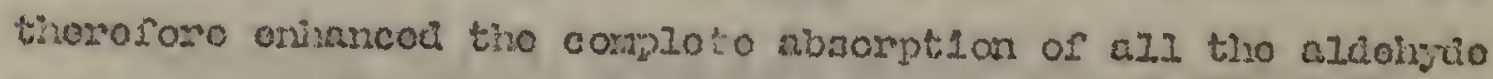
vupors whicir aletiliou over.

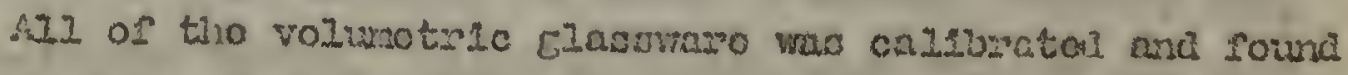
In rost casen to bo aurfaciontzy accurato to majo posesule ato

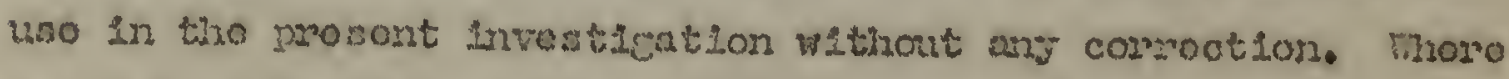
tho ormors voro Inree, tho propor comections wore eppliod. 


\section{B. Mochunters of the ostulation roaction}

It can bo shom by a procoss of olinination of othor possloll1tios that the nont sordous orrore in the dotomina-

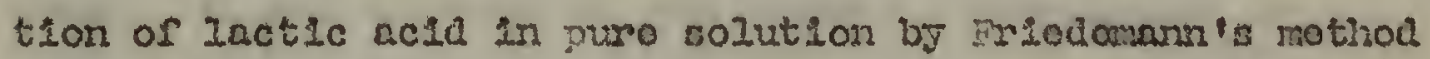

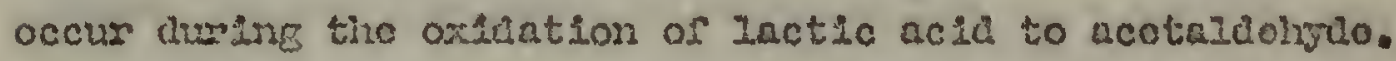
Mriocionaris (23) reportod that tho opros in tho titration of the acotaliohychoblarito solution 13 mali ma, thoreforo, is not rovponativio in itoclf for tho falluro to recovar moro than of por cont of a Imorm nolution of Inctic acid, To clinsneto tho oaly othor posalolilty, nanoly that acotaldohydo is not conglotoly abnorbec during aorution, tho prosent writor

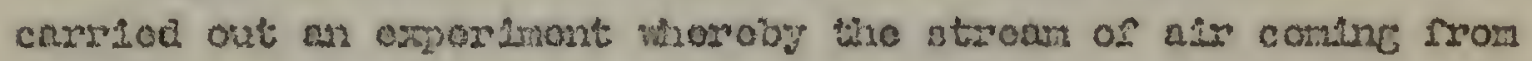
tho absorntion towor wns bublod tlwough an oxtraction rlask containing $10 \mathrm{ckc}$ or biculrito solution. Tio uruaz titration of the contonts of this rlask falled to roveal tho provence of any aldoingio in the solution, provins that absorption in tho tower was comploto. Thoroforn, in order to oxplain tho low rom sulte thore rexainod only tho possibility that the oxldation of lactic acli docs not follow the oract stolchlonetric oquation writton belom:

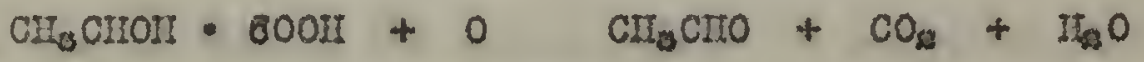

$$
\begin{aligned}
& \text { lactic acta inino ncotalio- (oquation 2) }
\end{aligned}
$$

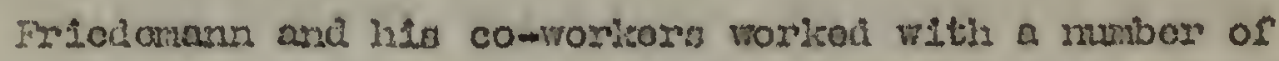
variablo fnctors 2 andor to obtain a masinur rocovory but, as nentionod bofore, faslod to obtaln roro than 08 por cont 
rocovory. As a result of their invostigation thoy reconmended an optimux acidity, manganous lon concentration, and size of sample, as well as tho use of the propor oxidizing acent. It was the hopo of the present investicator to further improvo the vield of acotaldenyie by a furtier consideration of somo of tho points involved in the oxidation mechanisu. Actually, no furtice improvomentz have becn made, althourh cortain observations have bcen made concoming the reaction which seem worthy of nention at this point.

\section{Comparison of the Relative Functions} of llanganese Dioxide and Potassium Permanganato

The orleinal mothod of Fricdomann, Cotonio, and Schaffer (29) described the use of an oxidizing medium consisting of a dilute solution of potassium permancanate similar to that used by workers before them. Friolcmann, Cotonio, and Scharfor found, however, that the prosence of mancanous ion in the solution containine the lactic acid had the dosirable effect of increasing the rate of oxidation by the permangenate and, for that roason, they recomended its use in the determination. The function of the manganous ion, they pointed out, was to reduce tho permanganate to manganese dioxido as soon as it was added to tho lactic acid solution. Manganose dioxide, thon oxidized lactic acid. The reduction of permanganate to manganese dioxide takes place according to the following rouction: 


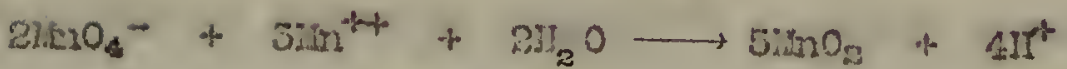

$$
\begin{aligned}
& \text { (Tquation is) }
\end{aligned}
$$

Shrco it is tho nauganoso isorillo that is tho actur? oxtaleints agent, it is oasy to sco vily tho prononce of tho

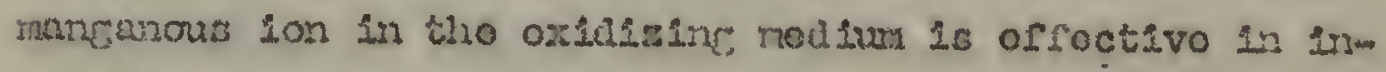
cronelng the pato of oxtlation of lnctic acil.

In a lator napor, FrLoi cmanu and Kondal (31), Introm aucol arotines chanco in techrigue for tho purposo of arroproving thozresults on complex slological materinlo. They showod that it ma moro dosirablo to uso colloldal manganoso dioxilo lut the ylsco of pexmmpanto since extranoous matorials procent in the Inctic acid solutlon which wero

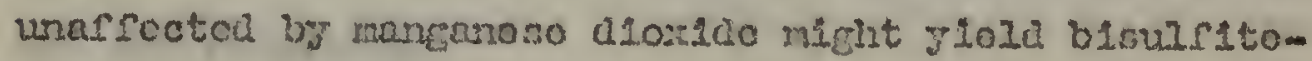
binding cubstances ir persanganato wero usod. Tho result on Iactic acid would bo the sarno whetiron pomangancte or ranganose dozide woro used asice poranganato, In tho

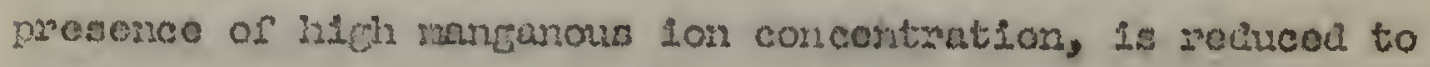
mancanoso diondelo boforo roncting with Inctio acle.

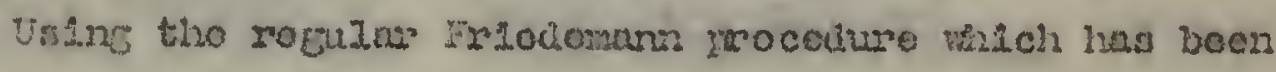
coscribor on pare 30 a sorlos of arajyos was mado by the provont writor in orlox to compare tino reault obtained by

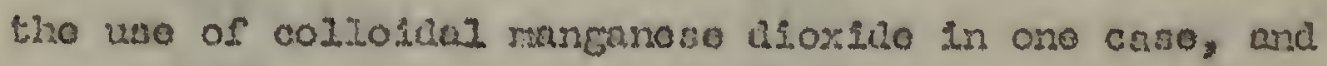
as Iuto potasalum resmuncrnato in tho othor. Tho proparation of a stablo cojzoldal eumeneton of maganoso aloxilo was a sourco of troublo at tho cutsot of this sorios of analgsos. Tho proparation dorcribod by Friodomann and KondalI (3I) Involvin: tho roluction of potaseiurs pomancanato by sucrose in alienlino solution vas flrst triou, urt it was imposelblo 
In two aleroremi nttoratis to proparo a stablo auponsion of

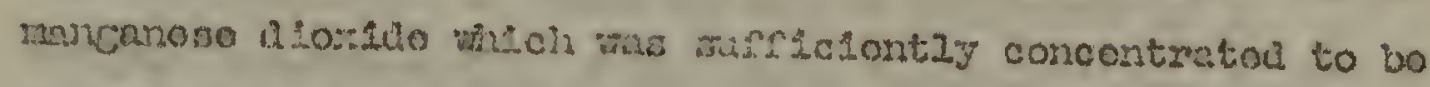
of mel1 uno ao an ox:dizing ngont. A thira attont, uning

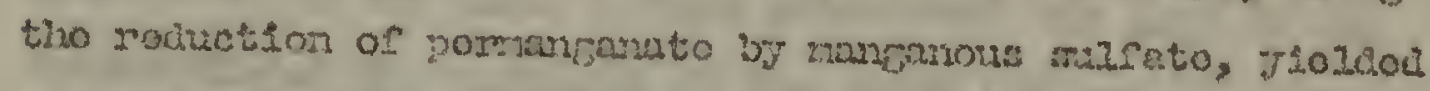

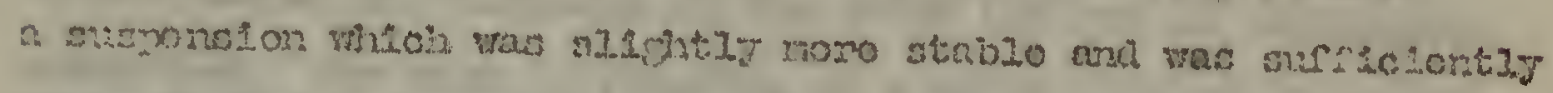

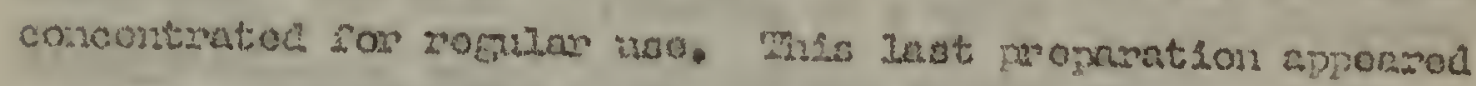

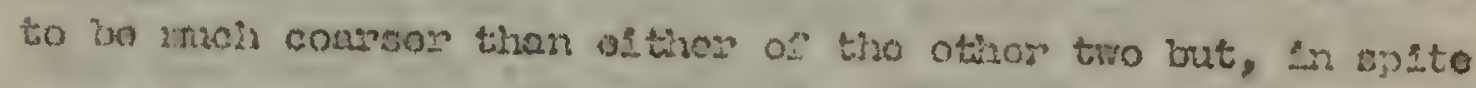

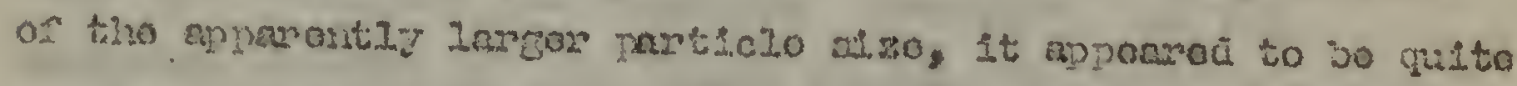

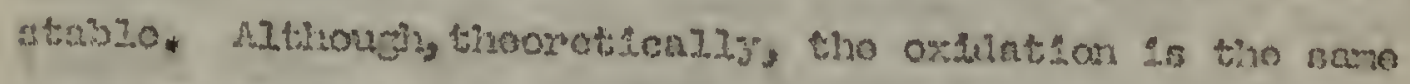
Whothor tho oxidizing agont is nunganoco diosido on pormangam nato in tro moanco of ranganous lon, tho rocults in tablo 2 show bhat tivero is a differmon of about 13 pon cont in tho

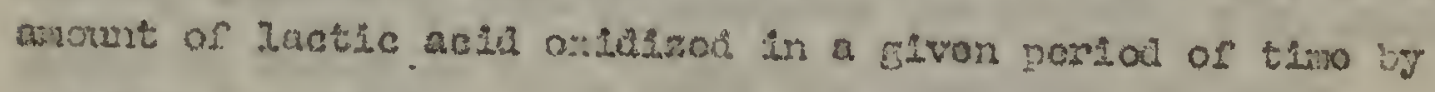
the tro rongonts.

\section{Tabio}

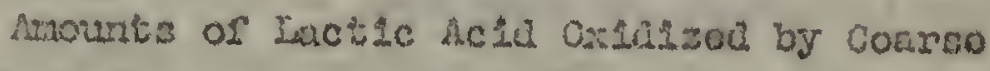

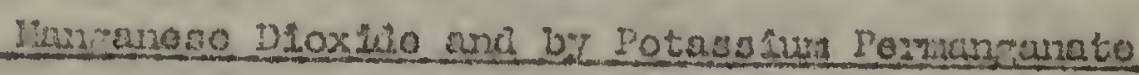

If. I. A. oxidizod by ling of I.

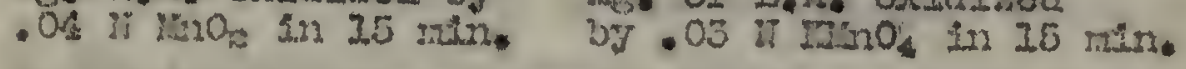

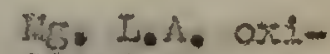
dines by 04 23 $30 \mathrm{~min}$.

$\begin{array}{lll}7.05 & 0.05 & 0.05 \\ \% .02 & 0.07 & 0.69 \\ 7.51 & 3.05 & 0.05 \\ 7.02 & 0.07 & 0.00 \\ 0.27 & 0.04 & \\ & 0.00 & \\ 7.05( \pm .34) & -0.01( \pm .06) & 3.04( \pm .15)\end{array}$




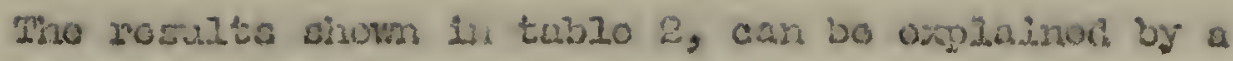
rusthor conalloration of tho facto involvol. 'Tho matanoso

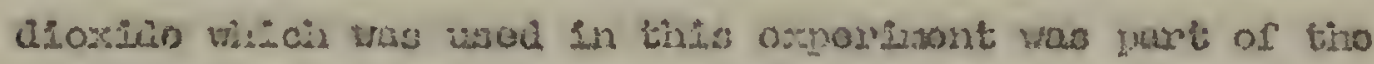

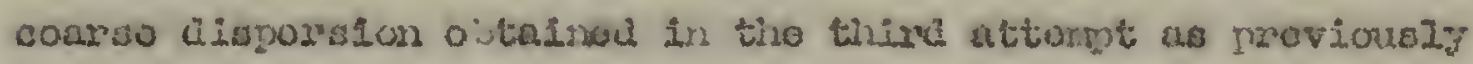
Loncribod. Tho rato of rokction of a solid main as marganoso

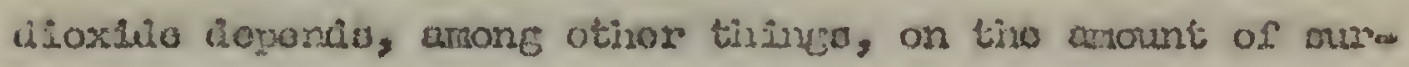

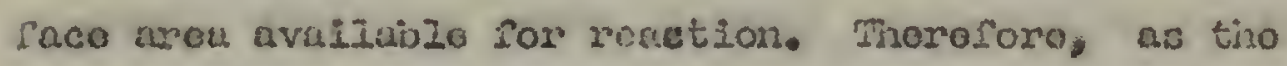
naureanose dorilio is moro finoly asvidod the rato of roaction becomos faston. The manganoso dioxide winich is fomed in

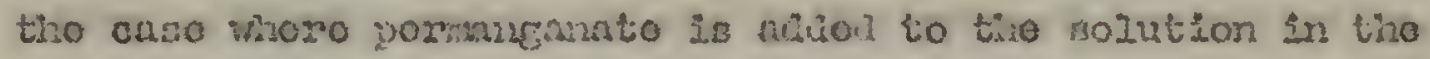
presenco of manganour lon, is in a vory finely alviliod stato and 13 , thorolosc, rocaly avaliabjo for reaction vith lectic aciả. On this otion hanl, whore tho provicusly jroparod

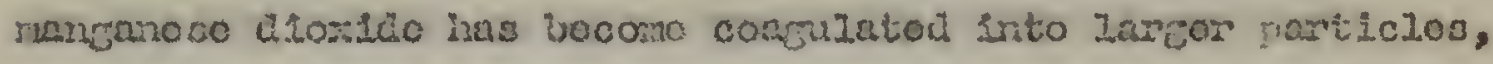

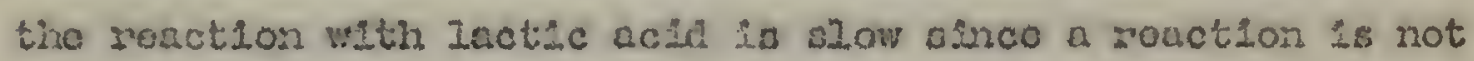

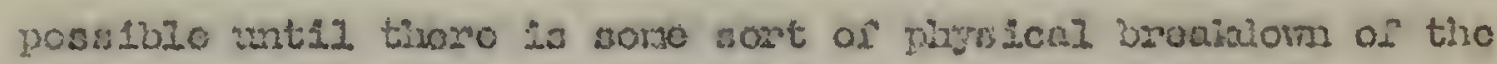

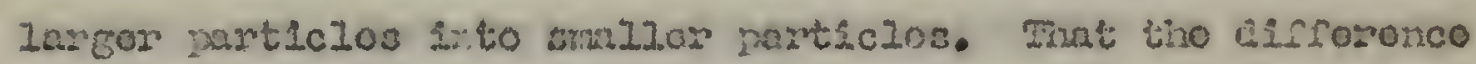

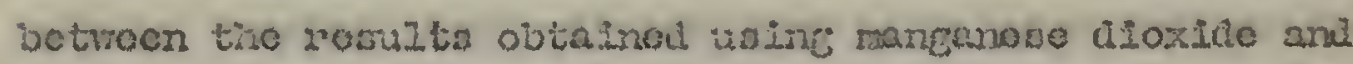
potassium pormuneanato lo cro of reaction mates is orought out

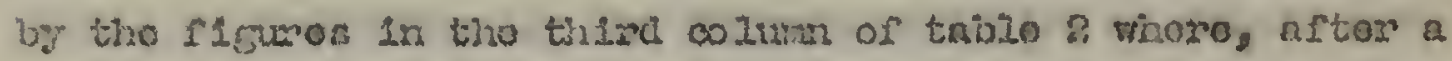
longer yorlod of oxtiation, tho roculta noro noarly appronch

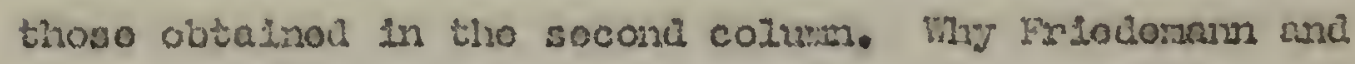
Rencall woro able to obtaln sqt3sfuctory looults which coula

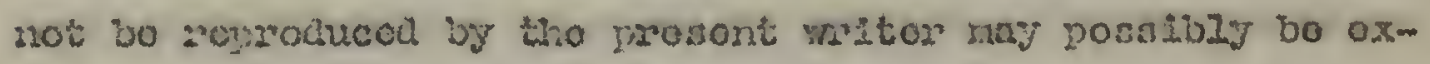
patined by oithor or botis of the following roasone: First, tho jroparation of colloblal muctioso aloxide, which

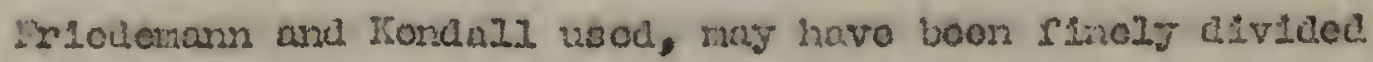


onough to approach the conditfons obta1nod where pernanganato Is addod to a volution containing mancmous Lon; socond, the $31 z 0$ of tho aample usod by Eriedonarn and Kondall was analior, in rost, caned, than woro thoso analyzot by tho propont writor, which fact may xoan that tho viortor oxilation pirstod Lis aufsiclont for maller somios bit not for the largor samp20a. This last point, howovor, has not boon consimod or donied by and oxporinontal work, and thoropore 13 only Hpothotical. In olthor caso permanganato apyoarod to bo tho better oxidising acont for uso in tho mosont invostigation.

Tho roason that diluto portaneanato zolutions havo boon Bound to Elvo botto: rowults than stanganeno dioxhio susponsions 15 easily oxplalnol. It has elroady boon bhown that tho roanon for tho 10 romilts using a provious 13 monarod manganece Aloxido ausponelon is shat tho rato of ronction of tho rolutively Iargo nanganose dioxido particlos is slow. "io spoed un tho ronction and, thorofore, to inprovo the sosulto it is nocosangy

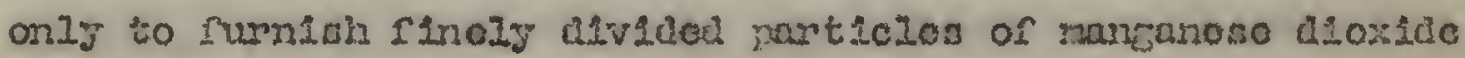

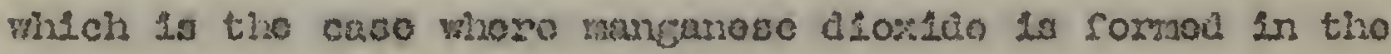

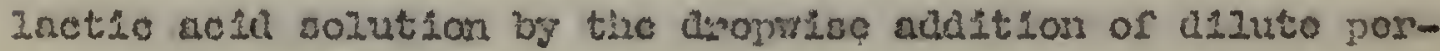
manganato in the prosonco of a inein concontration of manganous 10n.

That the stato of divialon of tho manganoso diozilo tuzponelon ie smpontant 3 ahorm in tablo 3 . Tho manganoso dioxice usod In obtaining those sobuits was some of tho amall amount of shtiefactory ouwponsion wicit was obtalnol in one of tho two rinst attomta at maitine a collowlal magonelon. Tho particlo alzo of thio atsponsion was noticoably salloz than that 
of the mangarxoso dLomlio particloc in tho asponason unod in obtalinirs tho rosults $1 \mathrm{n}$ tablo 2.

\section{Inblo 3}

Aroumte of Inctic Aclo Oavaluea by Elnoly

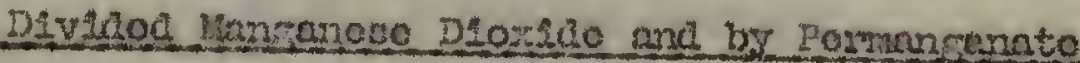

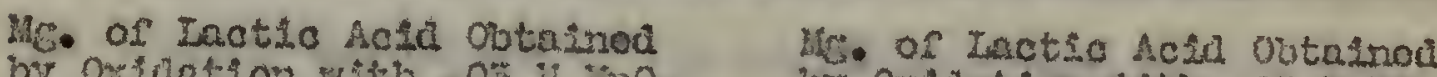
by oxidatios vith . 05 if ino in 17 minutos.

uy oxluation thith .03 II Inino In 10 nofrotos:

0.51

0.01

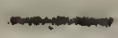

0.80

8.32

0.85

Average 9.66

Avorago $\quad 9.05$

Thus, tho mocults obtelned ustne the noxo sinely divilod marganoso d2oxido moro noarly approach thoso obtaknod usins pormanganato than do tho robults using tho combor nancariceo dLaxdo, tho aleforonco boing ands 1.0 por cont in table 3 as comprach with a afreronoo of 13 por cent in tablo 2. 27 o lxportunce of tho perticie sizo of manganoso dioxido 1 at 111 furthos ahow: of tixo rollowlug expertront. If aIz of tiro poxianganato to bo unou in oro of tho oxtcationa olmilar to thoso in tho aocond colum in taulo $z$ is zadal at onco at the beginnine of the oxidation period rathor than aidod arop-

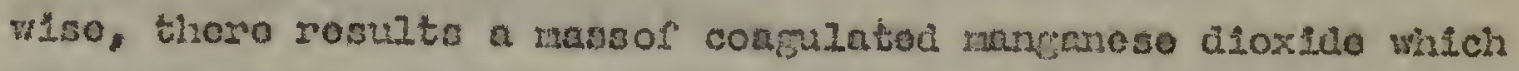

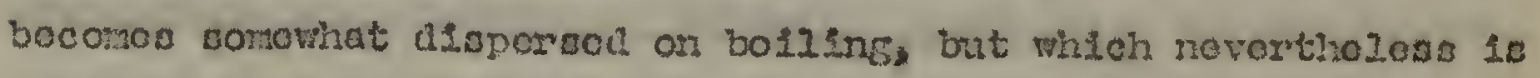
ration coarne in regand to particle civo timoughout tivo oxidition. 


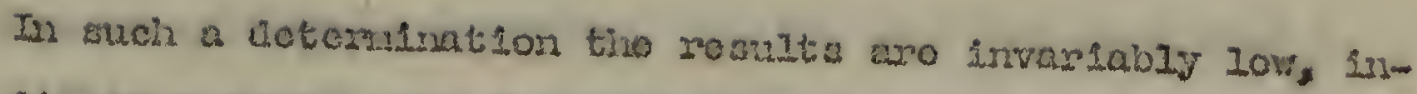

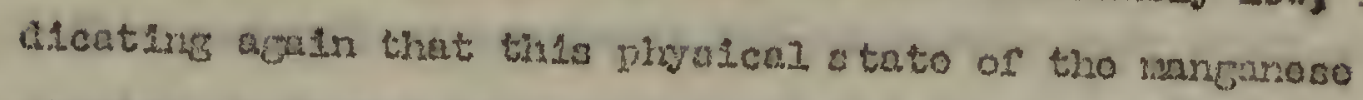
daride particlea ia vory important in tho oxilution of lactwo acta.

\section{Tho Occurironce of laneanlc Dhoaphate in tiso oxidation Reaction}

Durling the courne of tho prelininnzy worle on the technique of the methol, It was notscal that thore whs formod

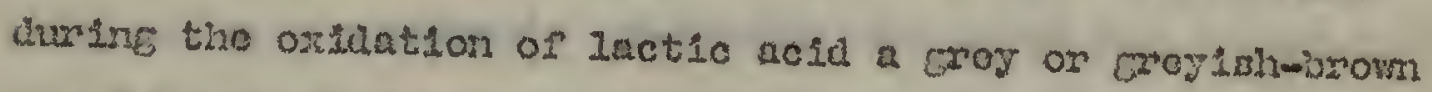
precipltate, the composition of which was unimona at the tiuo it was obarved. Lator on, aralyois of this substasco mowa?

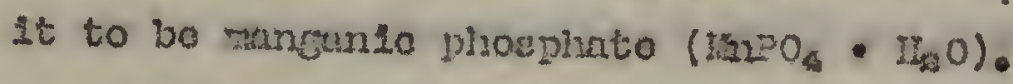

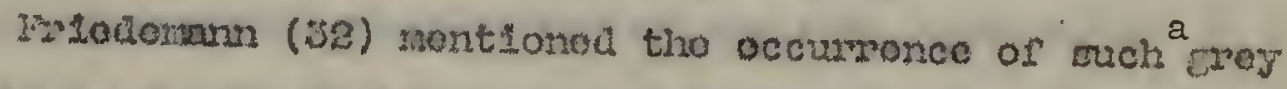
procipituto but rasiec to doccisbo ofthor its aproarnaco or position in tho roaction. It was thoucht that tho soolntion and liontirication of thia inionom substunco aicht rovord information wisch would be valuablo in worleing out tho rochanlam of tho roaction. Although the uninown substrinco actualy turnod out to be the product of a sido renotion and not necoscarlisy a part of tho maln oxidation reaction botwoon manganeso doxthe and lactic ncia, a distuesion of the compound which was lsolutiod wi2I be includal horo alrce, to tho mowledgo of the writex, such a alacuaston has not boas roportod in connoction vitiz tiliz cetorrination.

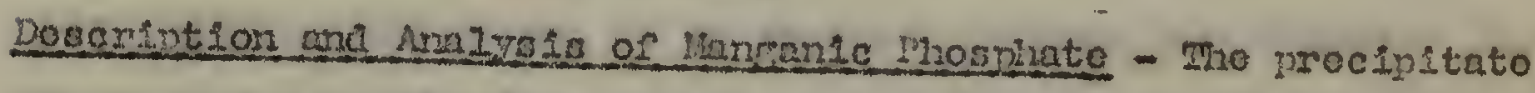
occurrod as a guato intolublo croy or Eroyish-jorom oubtanco which ras voxy rinozy dividal and whin sottlou out rathox stowy 


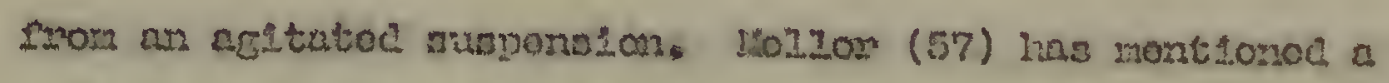

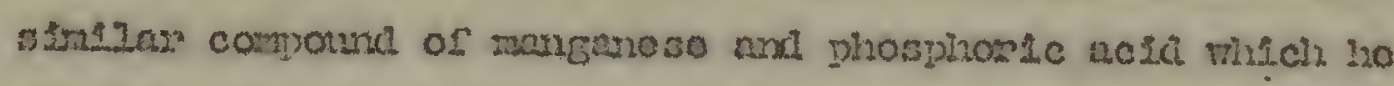

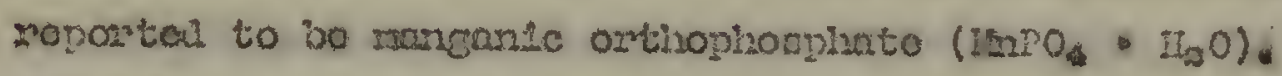
Accorular to his stataments, mancaule orthopizospirato is a vory

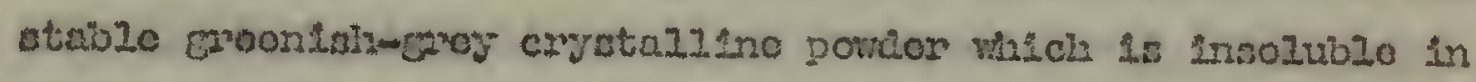

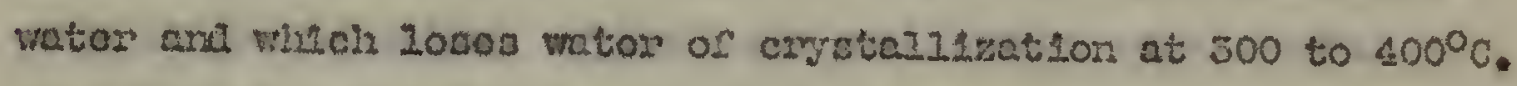
Wo accurato solublity moakuraronte havo boon roported.

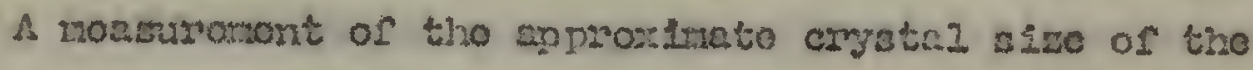
proctpitate was rado poosiblo by a alrect microscoplc oraminatwon, ustre a proviousy colibratod ayo pioco and a hist powor arg objectivo. An ozominntion of sovoral arforont microscoplo flolas 1ralcatod that tho avoraco asamoter of rangante phosplute

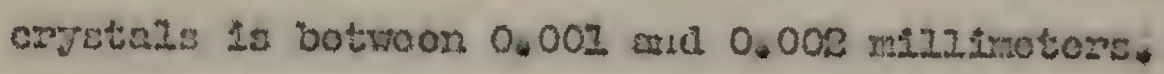

A alcrosconic oxaringiton of tho atmo precipitato in a

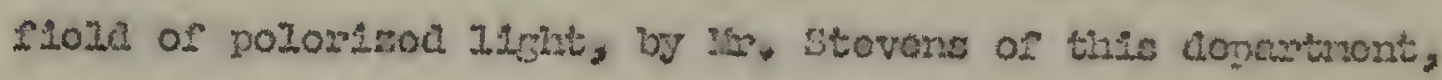

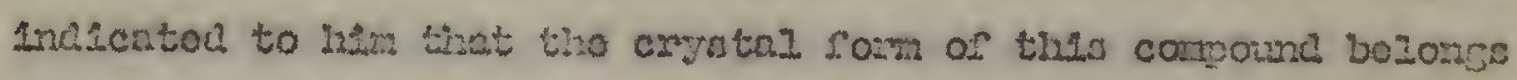
to ono of the timoo following classes of crvetalinio atructuros: (I) monoclintc, (2) triclinlc, or (3) ortiorisoniblc: Tiso crystals, accorusis to $112 \mathrm{~m}$, could not be inomctric, totragonal, or hexagonal. Inte conclusions woro basod on tho ract tinat in no caso vas thoro in any nicroscoplo riold a crystal which showod completo oxtinction of tiso polarizod lifilt by rotating tho flold tirrough an angulaw rotation of 3000 .

Accosding to obsorvations mato by tho IFosont writor, tho compousd goos suto colution vory slowis in tho prosenco of

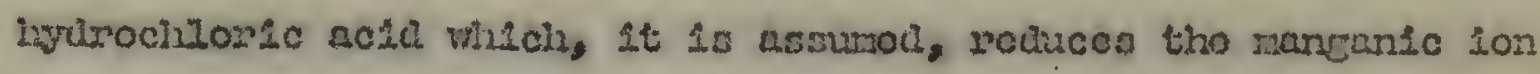

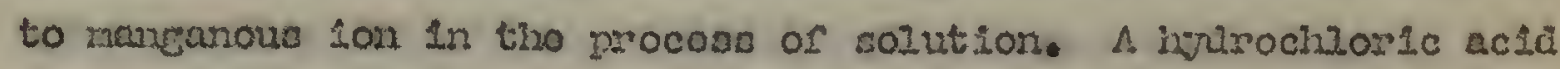
solution of tho procipltato containod onfy naremoso and 


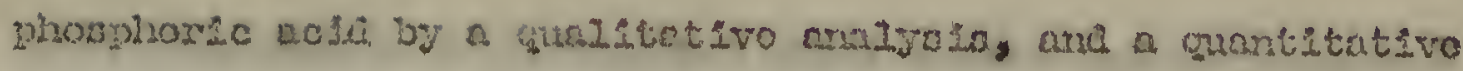

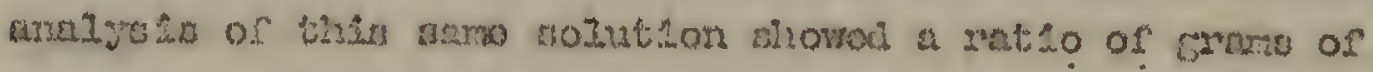

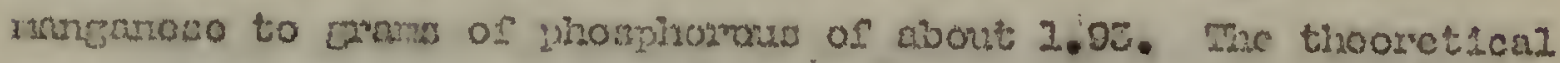

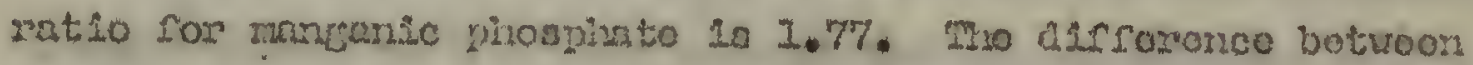

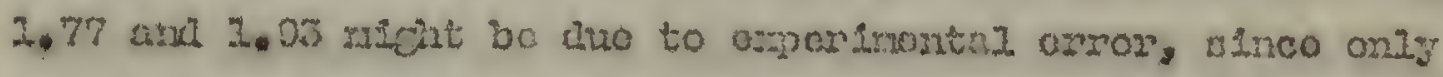

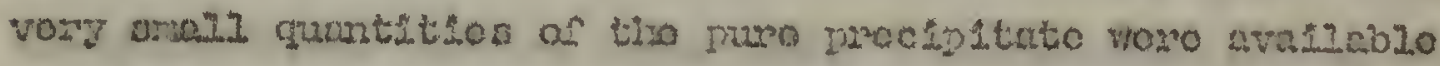

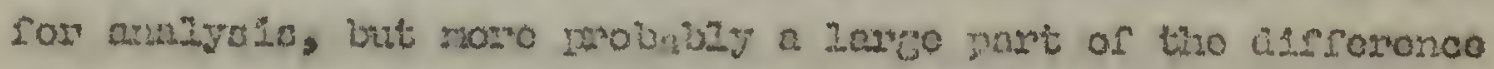

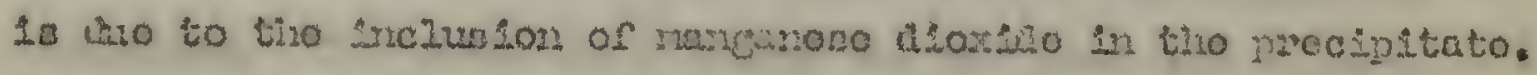

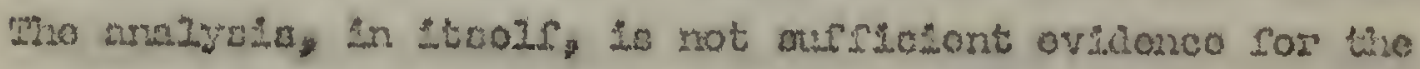

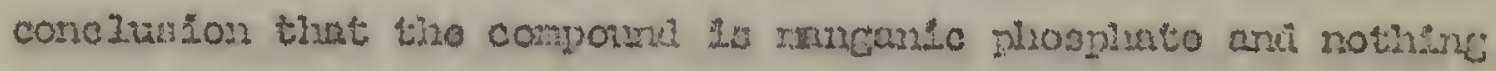

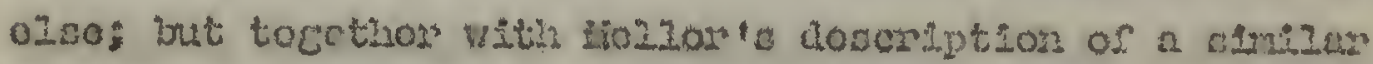

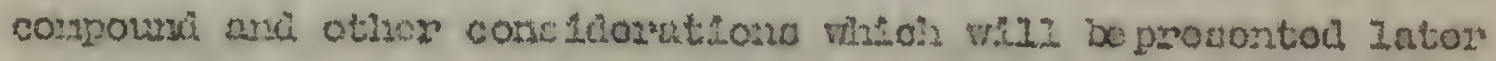

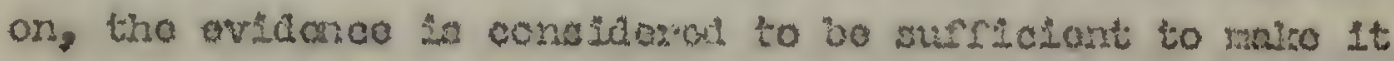

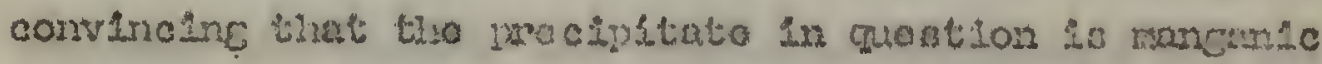
phosphata.

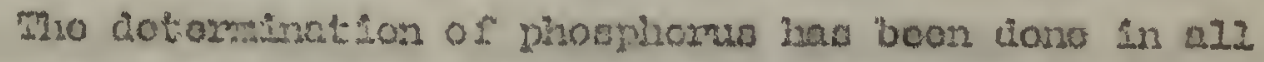

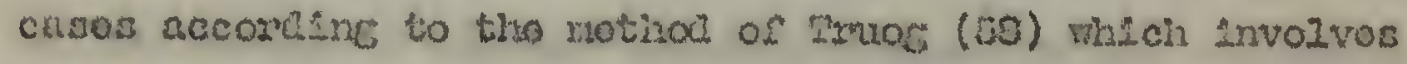

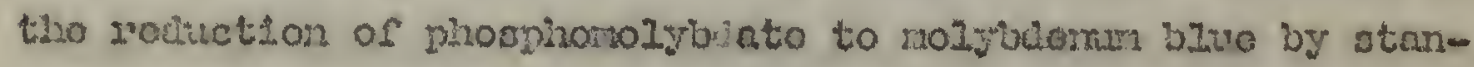

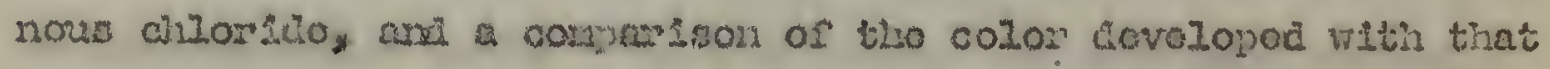
dovolonoci by a ctancard phaophorru sozitton. iancanodo was

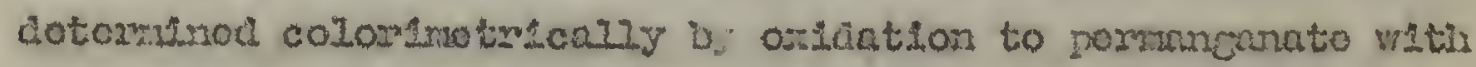

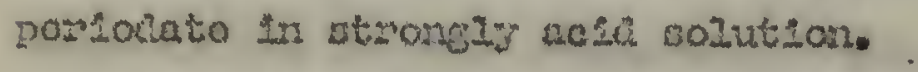

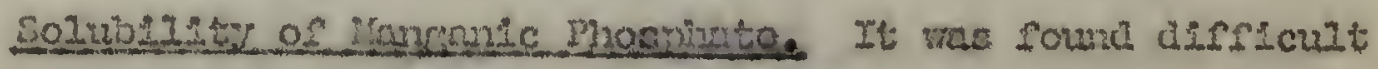
to obtain accuarto inrommation ng to tho orsot soluvility or

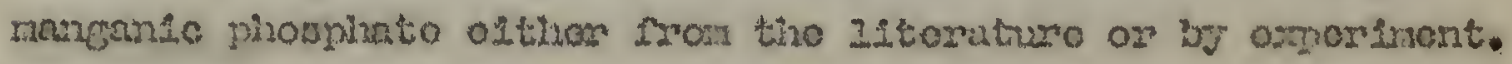

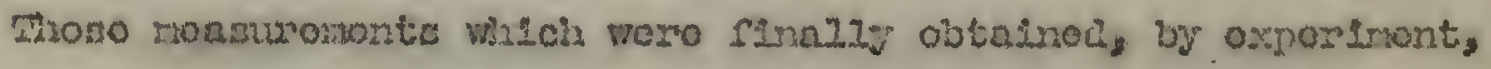

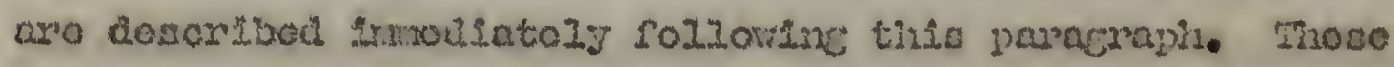

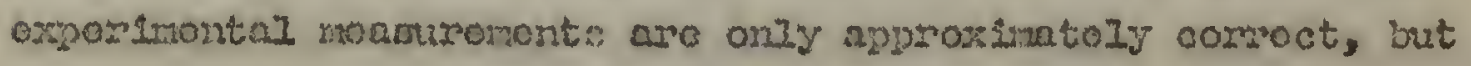




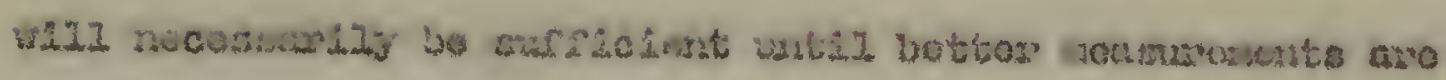
macio.

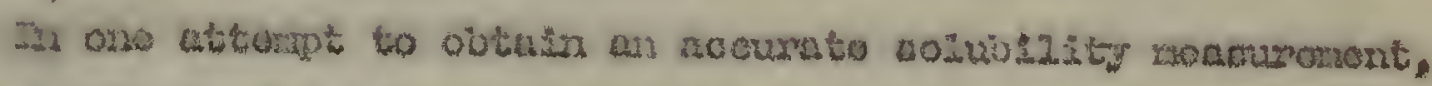

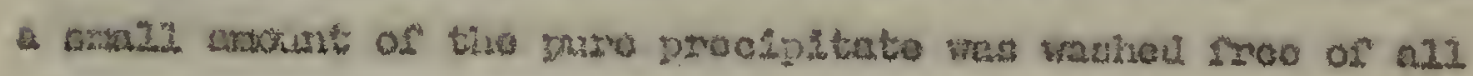

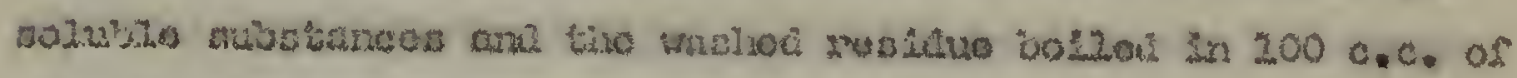

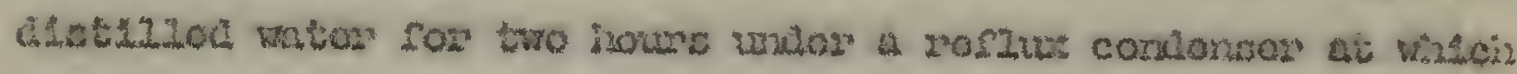

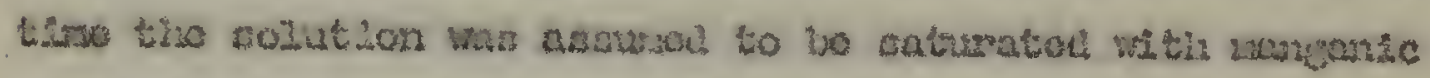

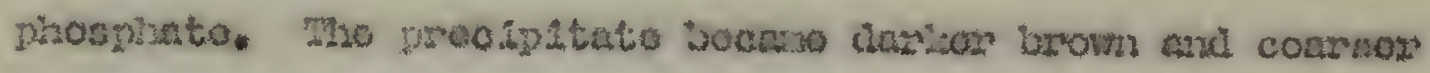

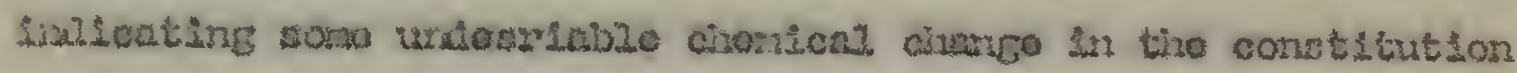

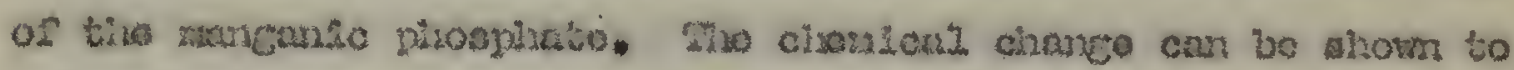

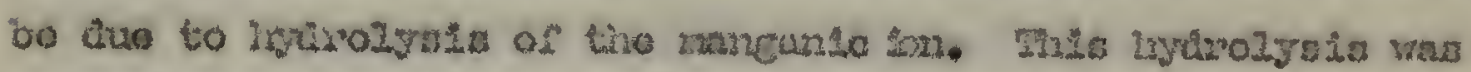

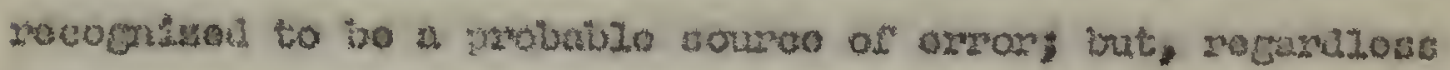

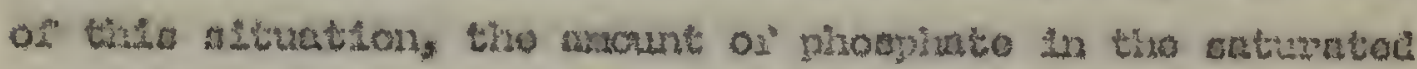

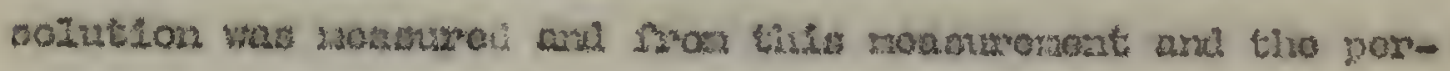

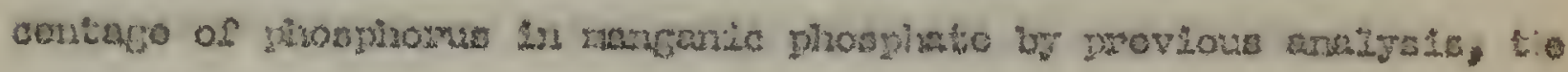

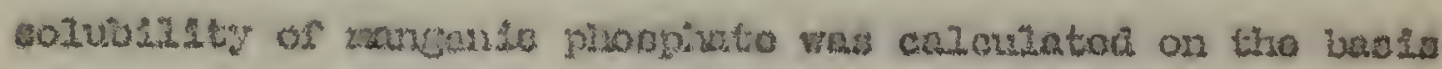

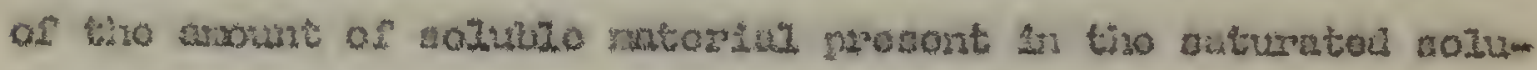

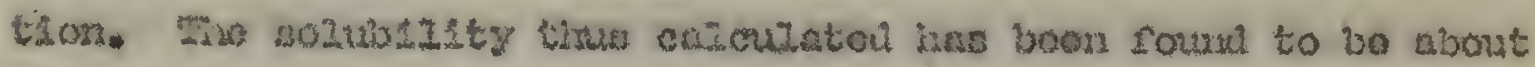

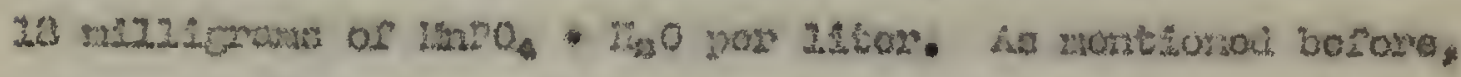

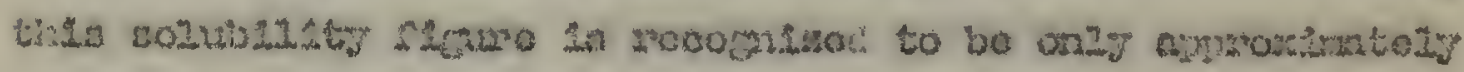

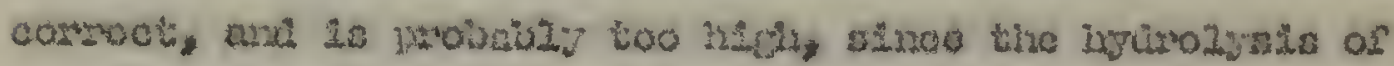

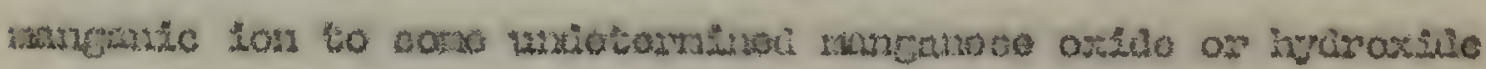

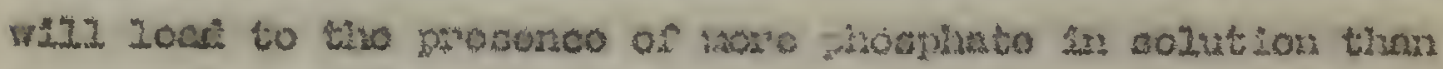

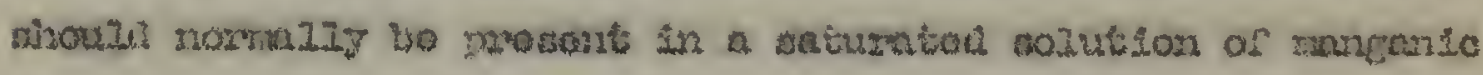
phoopinta.

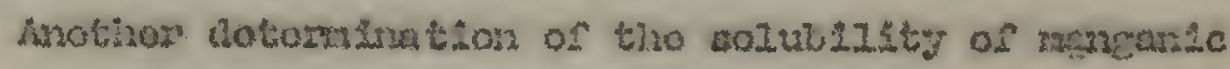

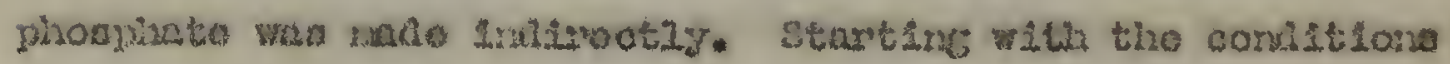

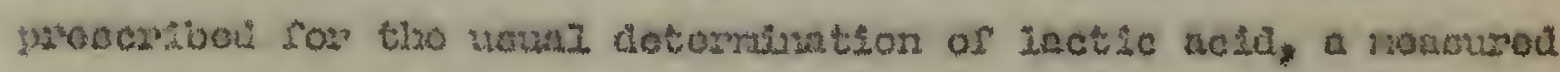

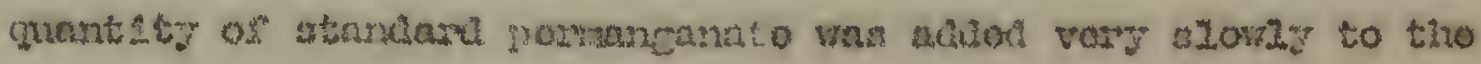




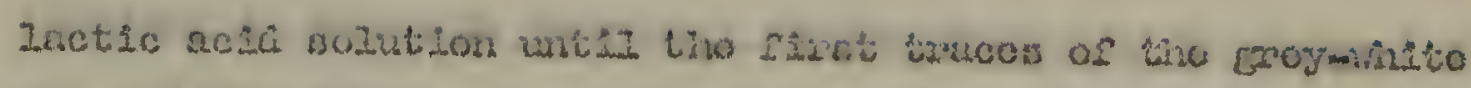

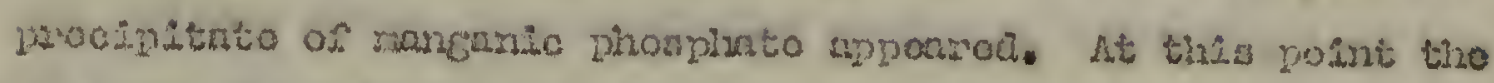

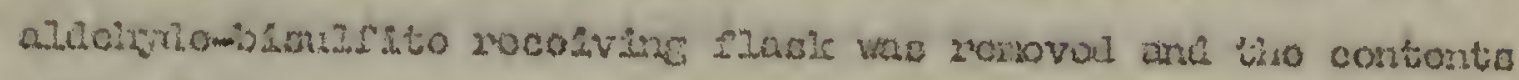

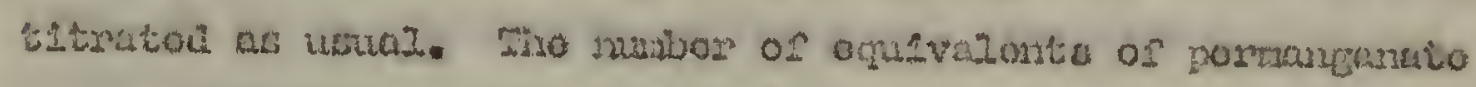

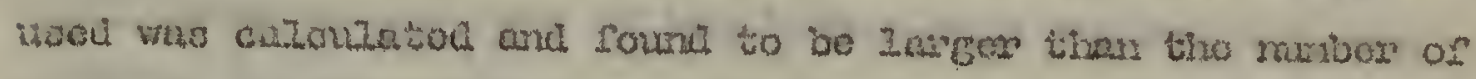

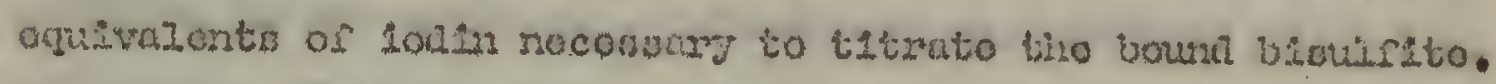

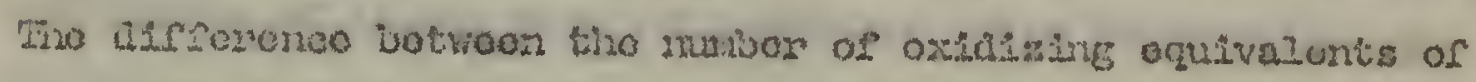

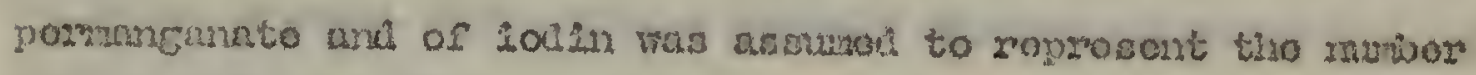

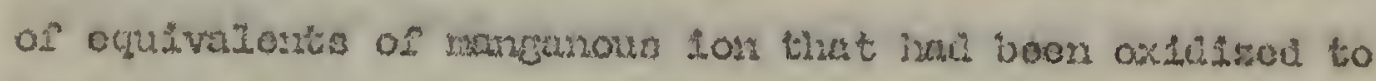

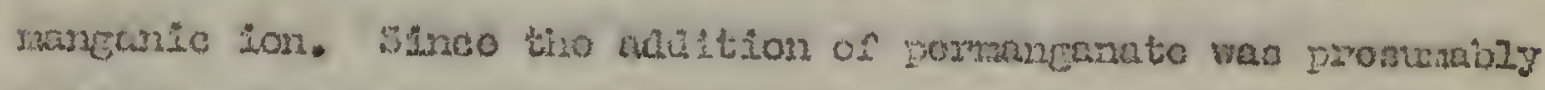

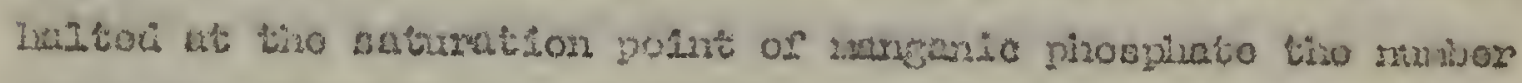
of oquivazonte of manganie lou mosont sn nolution at thet point

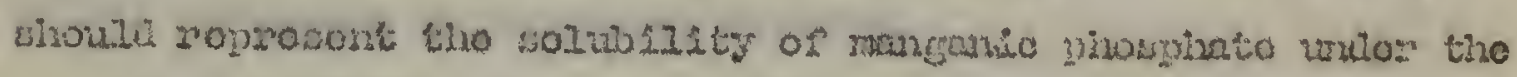

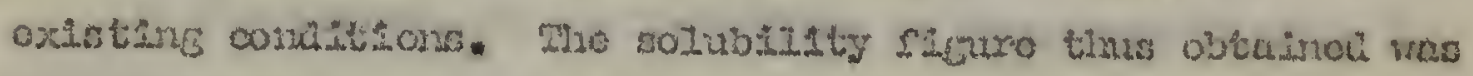

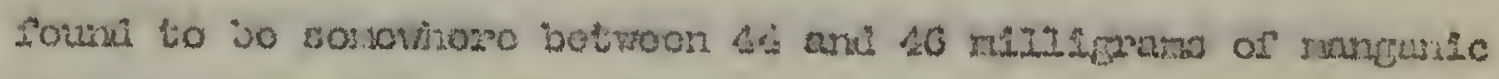

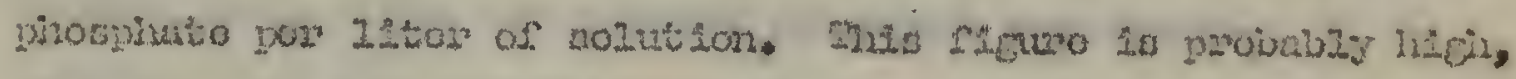

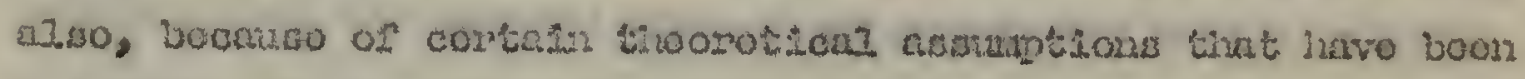

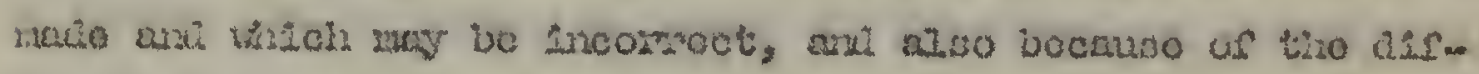

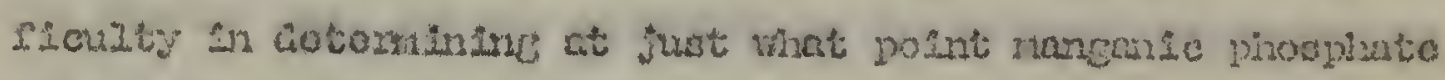

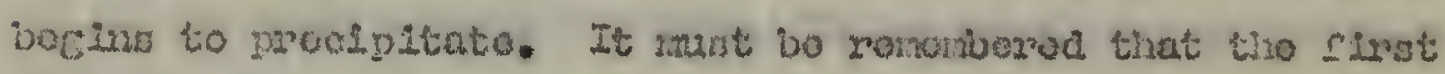

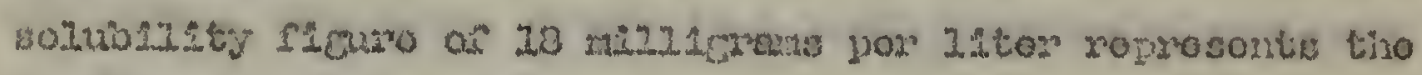

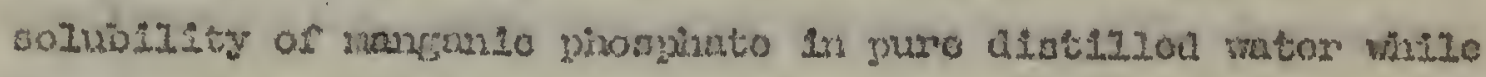

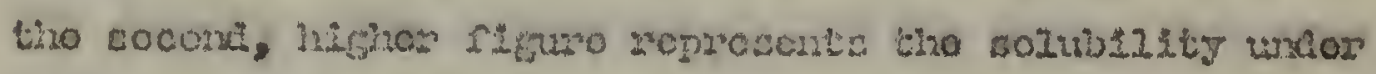
ontroly difroront conititions. At ary ato, th la safo to

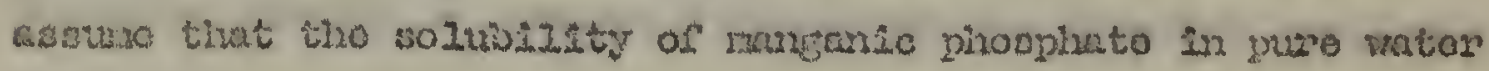
and in solutions cuois as tho ono wou en tho oxilation or lactic

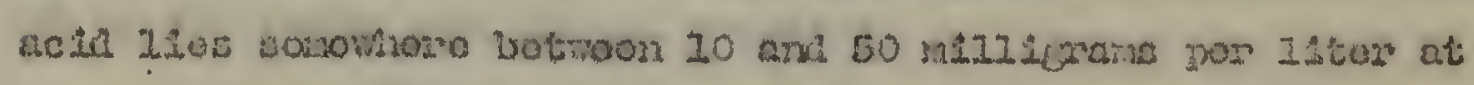

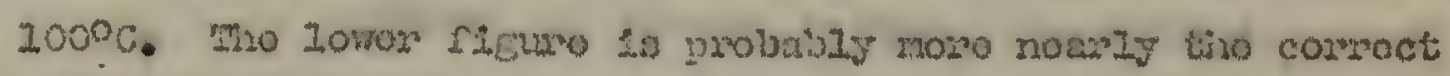
ono. 


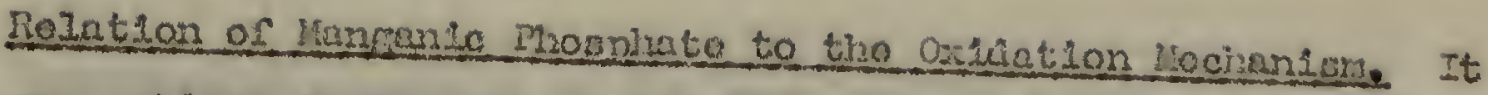
was not lood during ono particulur scrios of dotorninations that If tho pexranananto soro ndiod vary blowly and oach urop alIowol to react complotoly, no maykmono piominato was romod

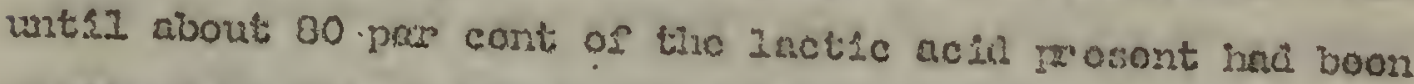

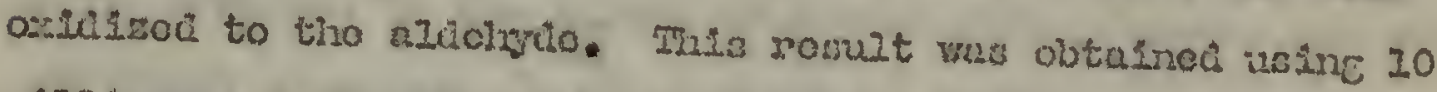

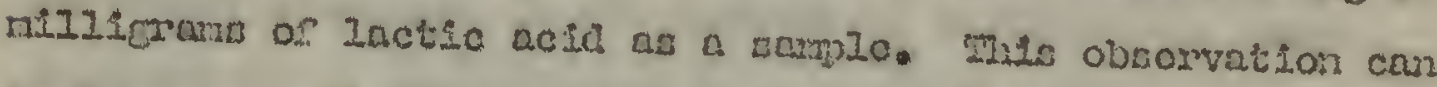

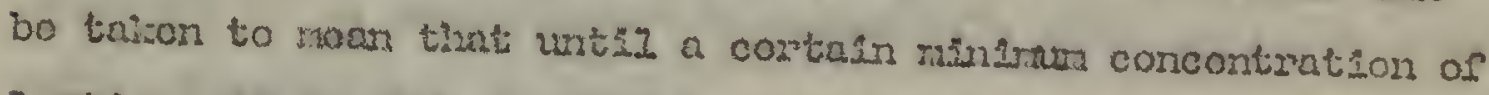

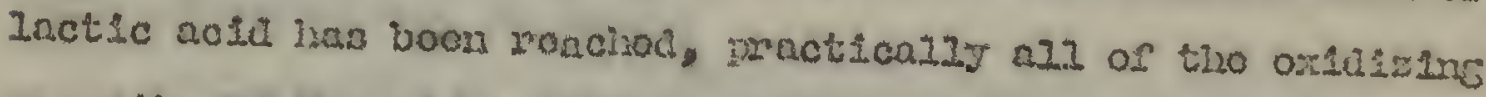

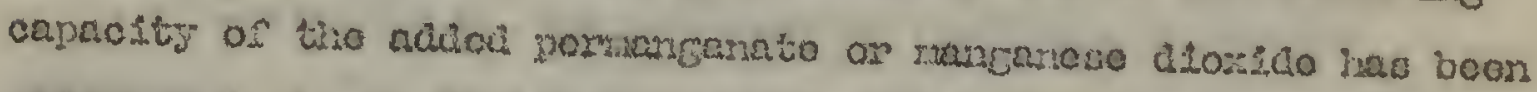

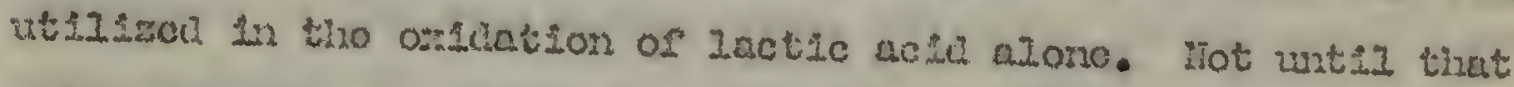
point has boon Ioschod is bIvelont mangnnoto orkalsod to tarivalont mangmewe by mungriedo atorilo.

In tho procoen of tho roluction of manganeso dioxilo by raducinc acents wuch as Inctic ceid thoro are two possibio vallonco forms which tiso roducod ranchuoso nay nosuro. It la posslito tint the roducod form of mancanose may havo a valonco of olthor two as tirrae, or both. If the trivelont condicton 10

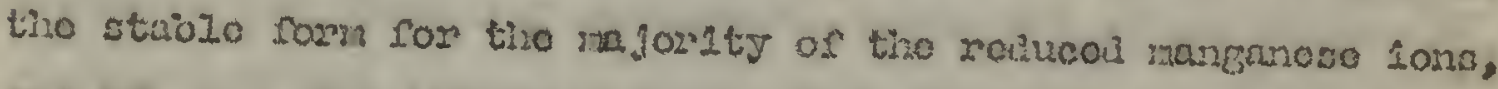

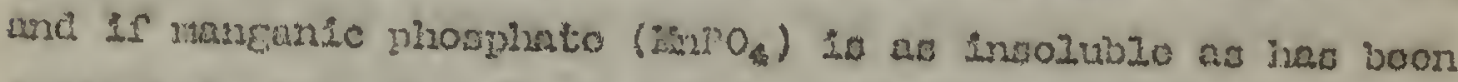
indiantod, tham thare ainorila vo a procipitation of mancanic

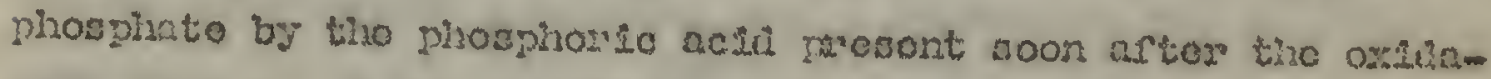

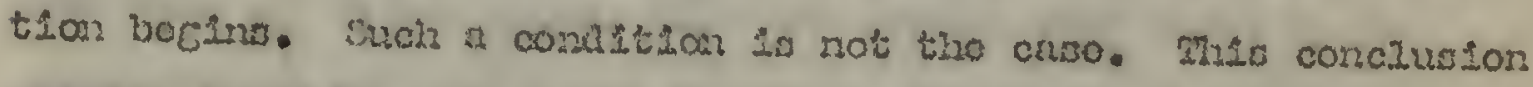

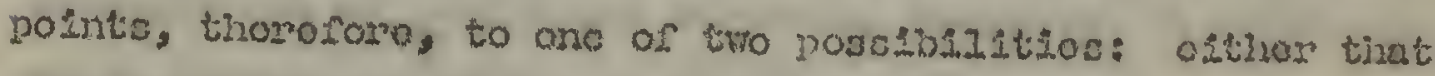

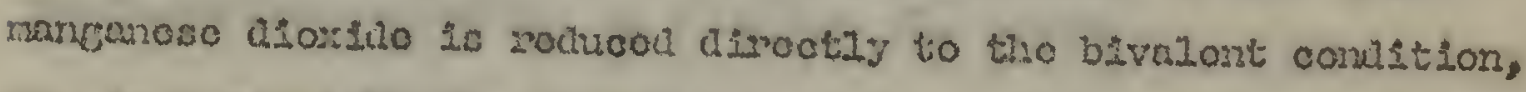
or, If Ireducad to tho trivalont coniltion, thoro is imoliatoly sot up tho rapid ogidilomium rouction:

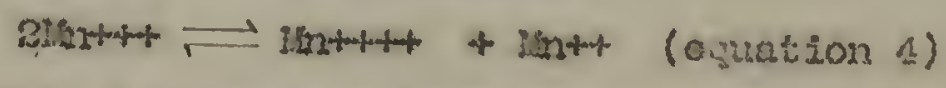

wiloro some trivalont nanymono lona spothanoounay rogonorato 
totravalent manganoso at tho ando thine that otjor trivalent fons

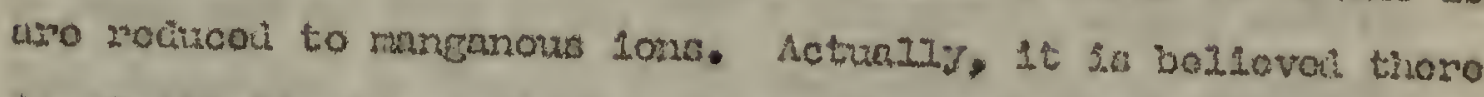

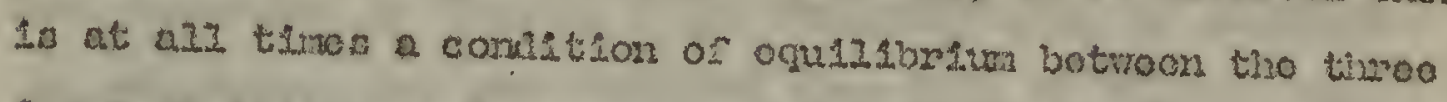

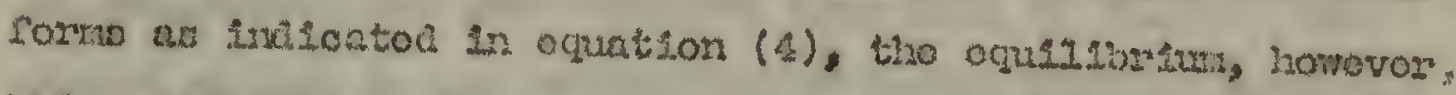
bolns arfoctod by tho artount of lactic ncid pronent, and that

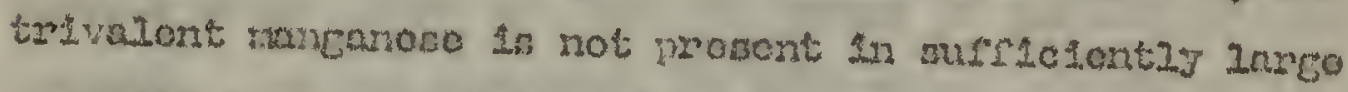

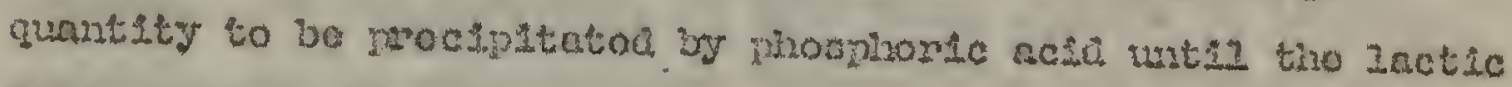
acla concontration 15 armiz.

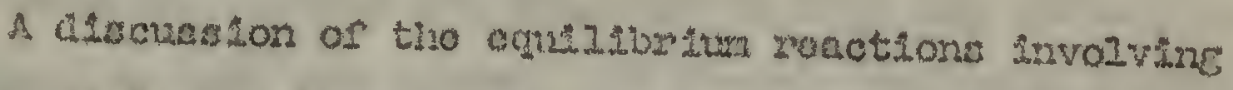
rangarace In tho two, turoo, fous, and sovon vazenco conditions was prosontod by Lanuos and zost (b0) su 1054. Fonoorulon and

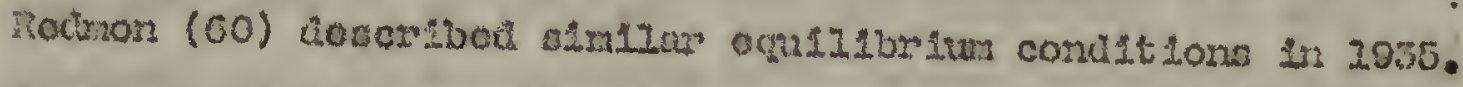

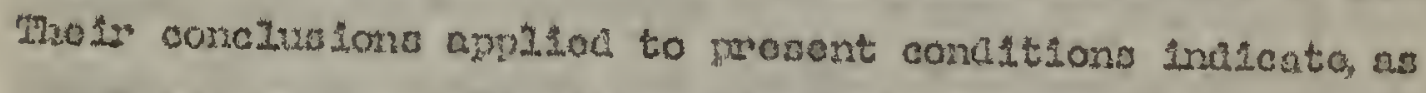

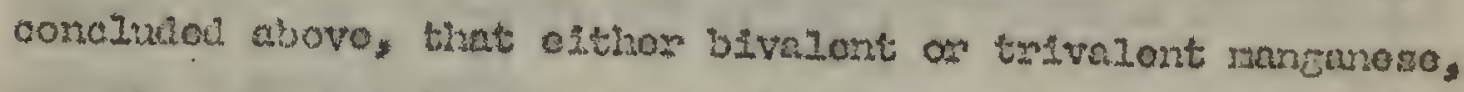
or botin, carr romut Srom tho oxination of Inctic acis by

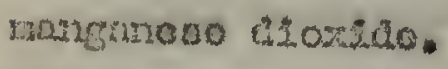

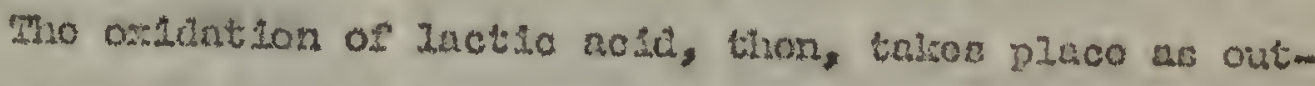

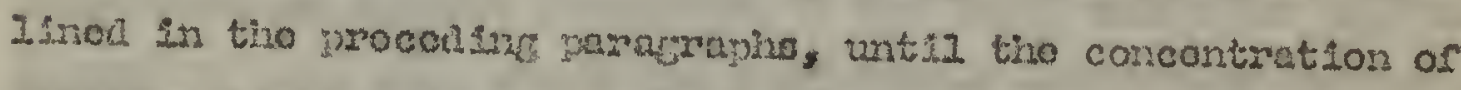
Inctic nosu has bocomo ao axhal tirat tho rato of ronction is

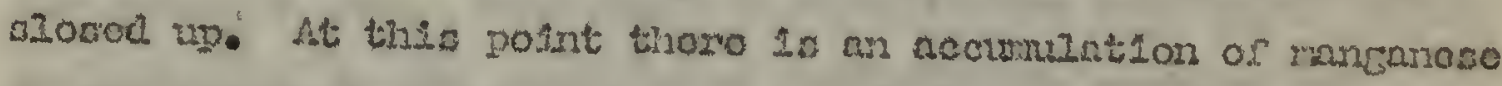
In tho totravniont condicton, und a rovorio of tiso roaction in cquetlon (4) talko plnco, whth tho pocult tint thoro is an acounutation of areficlont tritrazont rungarioso to causo 1ts procipltation accoratus to oguntion (5) bolow:

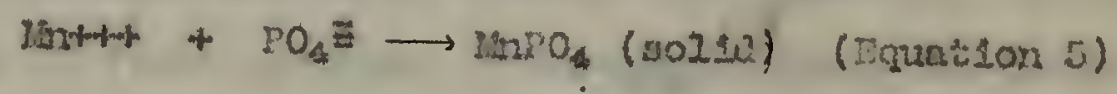




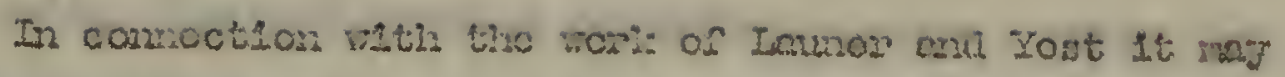

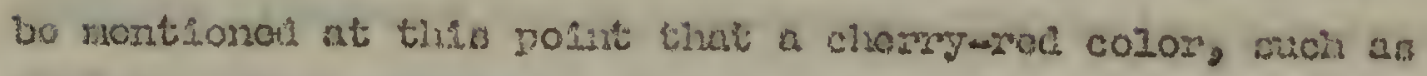
that doscribol by tron an bolne characterlatic of ramanic

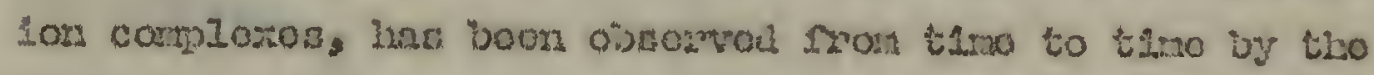
prosont urstor in tho oxliations of Inatic acid by nenganoso

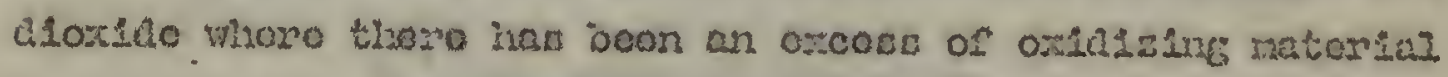

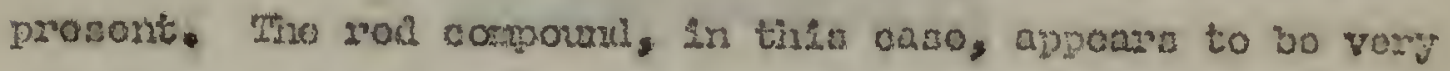
unnteblo, and no atioxpto iavo boen malo as yot by this investigator to isolato the comoun o* mako way furthor invostication into its nature. It lo vouy probobio, howevor,

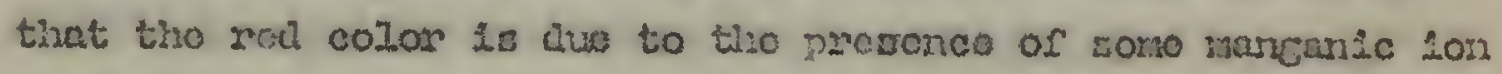
comploz, becutso of the fack that sto occurmonco has boon

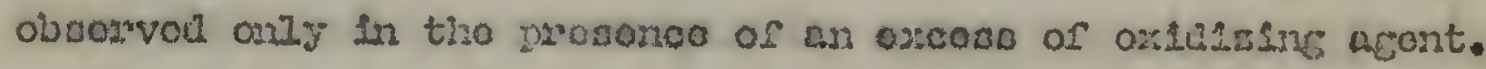

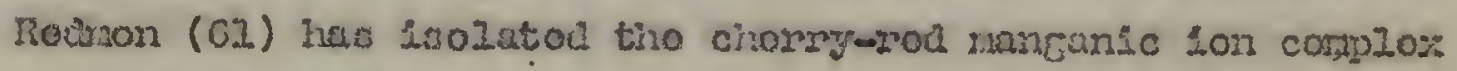
forriad by aralic nosia.

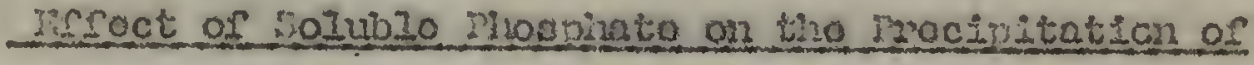

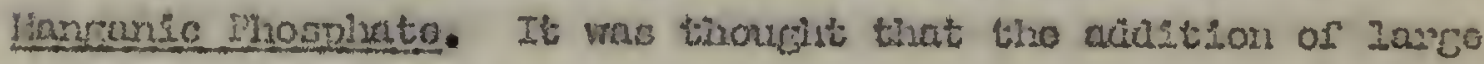

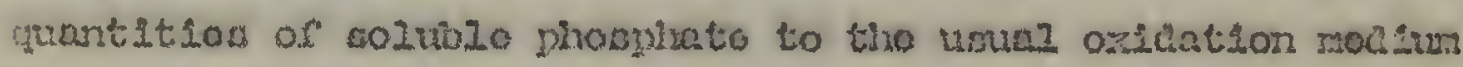

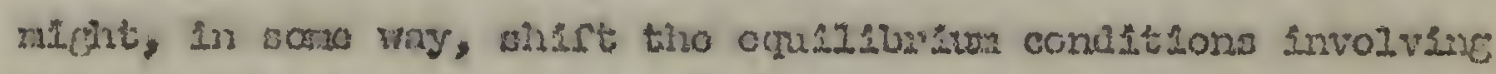

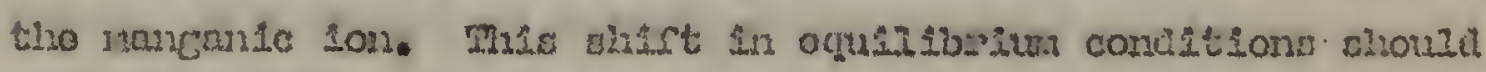
bo Indeatod by tilo guantity of acotaldohyao produced as

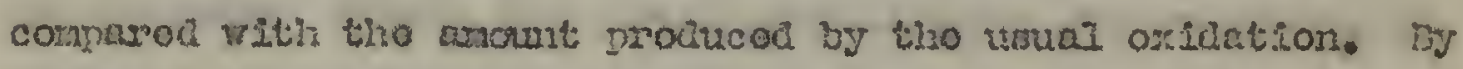

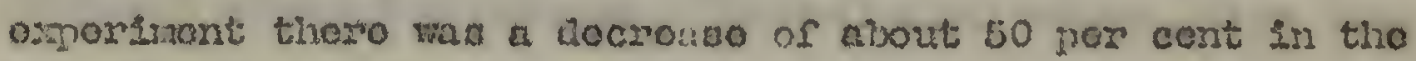

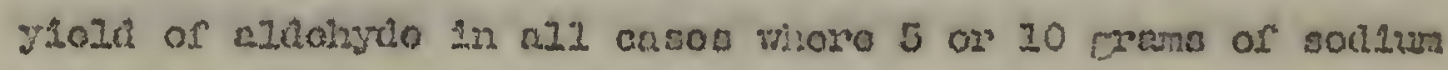

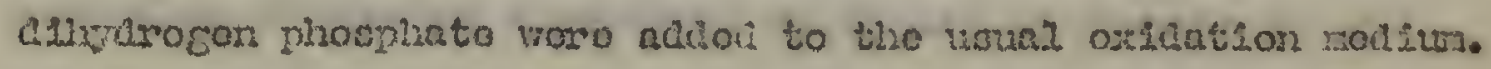

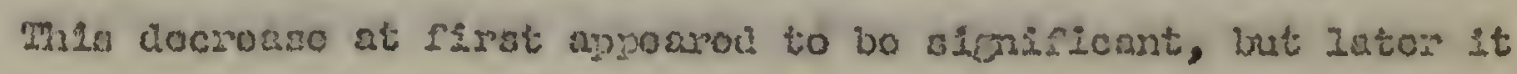

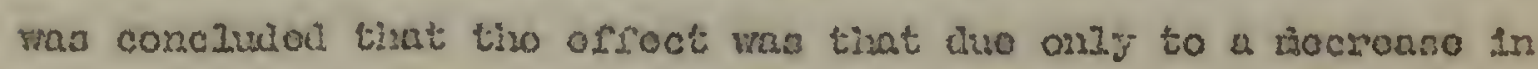
tho aclatty of tho solution becauso of tho buffoxing action of 
the salt. Tho lyturogon-Ion concontration has ulroady boen shown by frichomans and his coworisors (29) to bo an innortant factor: This particular lino of invostication was followod no further.

\section{Uso of Iff forent Tymos of Oxication Appazatus}

\section{The Aoration Proceluro}

The acration apparatus loscrived intho originn Inothod of Friodonann, Cotonio, and schuffor (29) was foum later by

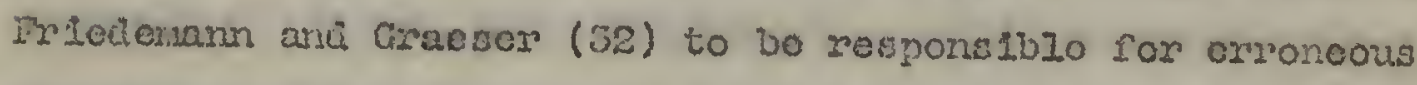
20sults bocauso of conditions whicl woro peculiar to tiheir Iaboratory at that timo. Tho alfiscultios oncountorod wore: Flust, tho prosonco of aldeiryio and acotono vapors in the atmosrhoro of tho Iaboratory snd; socond, as quotol in the authors' publishod papor, "an unusually colu supply of cold wator wimli mado tho rollut condensors too officiont." whose two coniltions soonod to be surficlont pecson for ilpodemann and Cracser (32) to discard tho old aoration apraratus and to incorporate tho uso of a slmio aletiliation apparatus ln ito place. As a rosult of investigntione carried out by the prosont wition, tisis chango cannot be justisiod for tho followine reason: First, tho sinplo distillation anparatus carnot postibly arford the aesined climinetion of vapors othor than ncotalichylo with aro sombtimes produced by the simitancous oxidation of forolen cubstancos which my bo prosont in the unlnom solution of Inctic ccil. Tho acrotion apparntue mitoc 


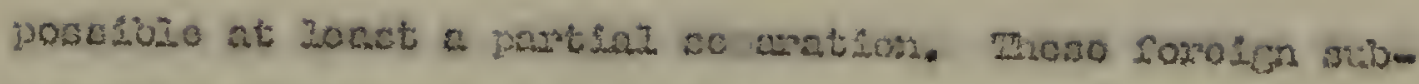

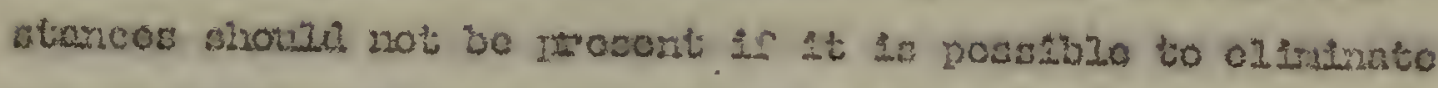
tilow, Sut 1s thoty aro mospat, tho allod grotoction of tho

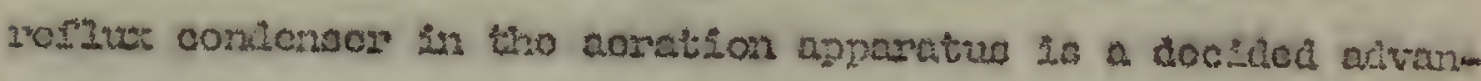

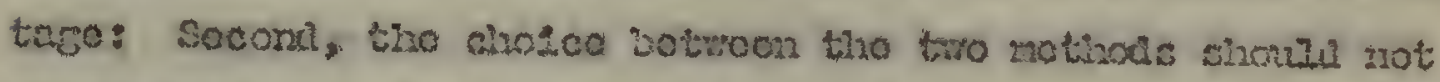

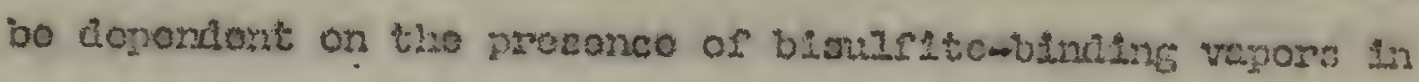

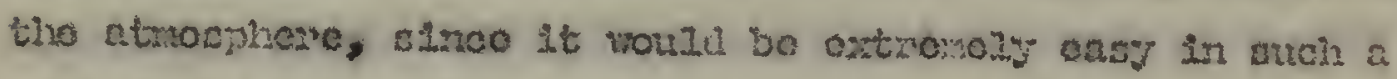

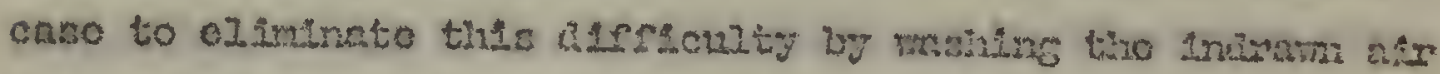

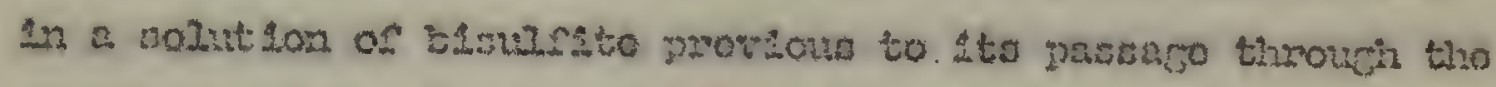

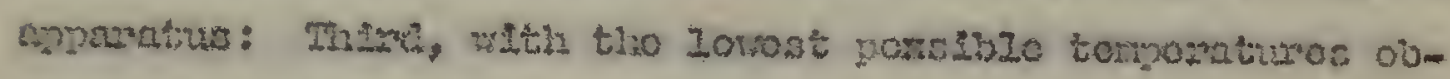

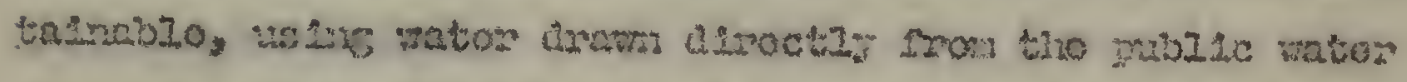

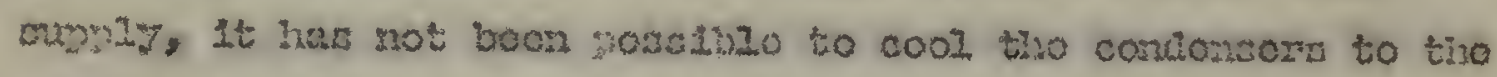

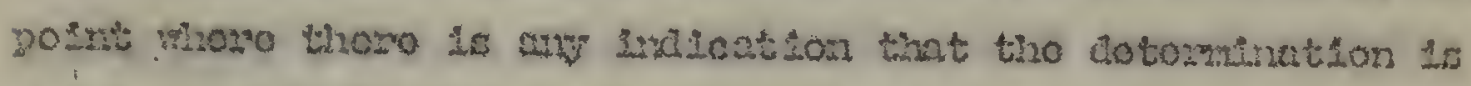

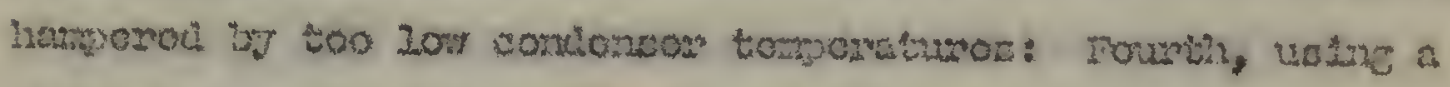

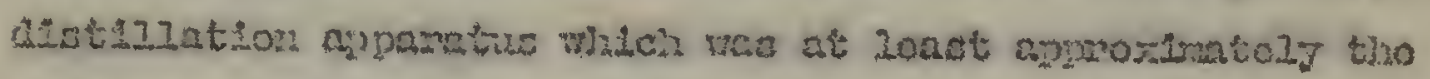

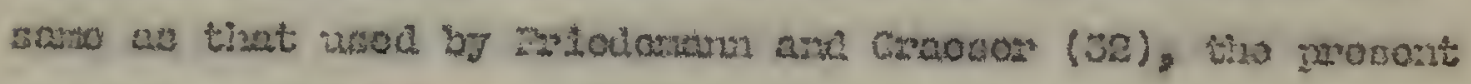
whtos haw boen unble to obtaln romulas which are at alz conm.

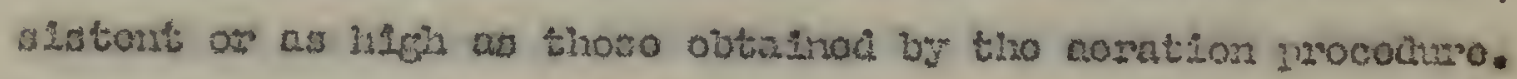

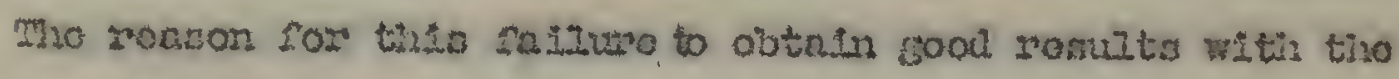

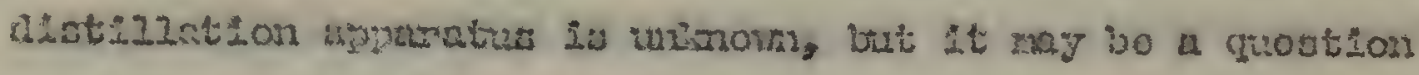

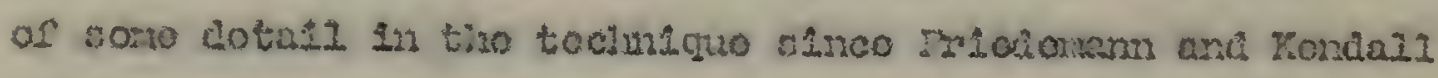

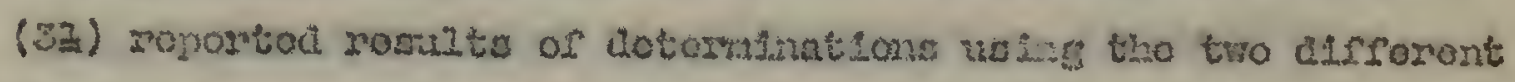

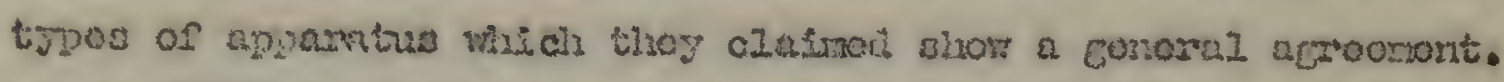

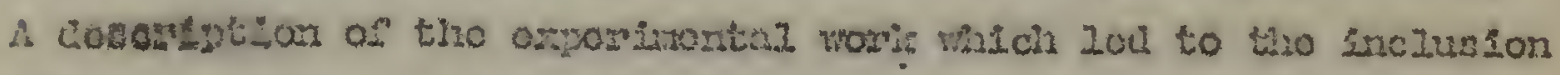

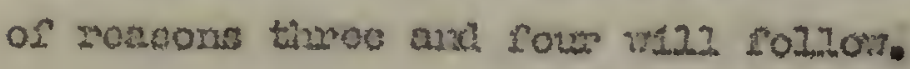

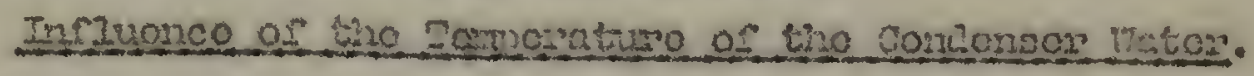

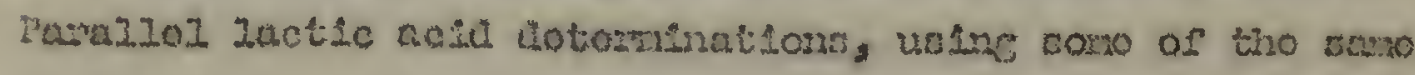

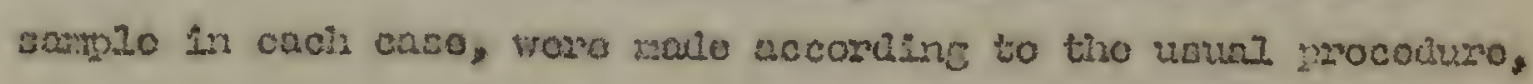


In ordor to dotornano tho Infiuonco of tho tonmorature of tho condonsor whtor. In one soxios tho water was allowol to rlow.

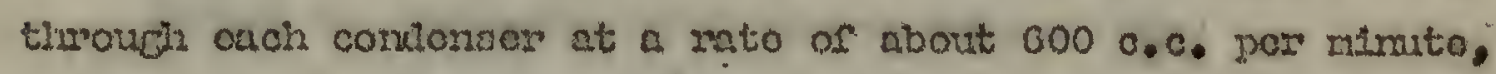
ontoring tho condonmer at $7^{\circ} \mathrm{C}$. and Ionvine it at around $10^{\circ}$ to $12{ }^{\circ} \mathrm{C}$. Who tomporatures of tho Influont and offlucnt watoro was noasured at two on tharoominuto kntorvale on $100^{\circ} \mathrm{C}$. tinor-.

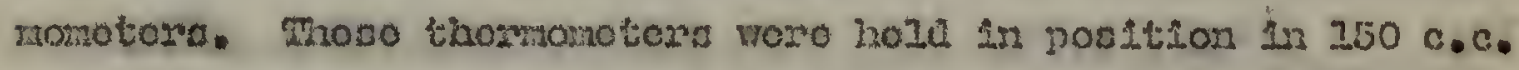

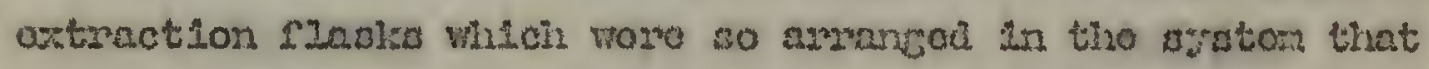

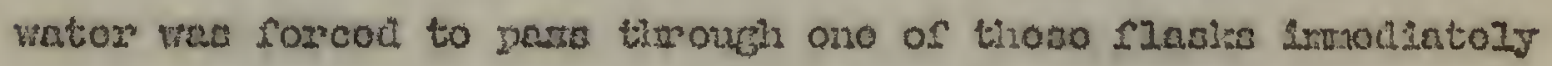

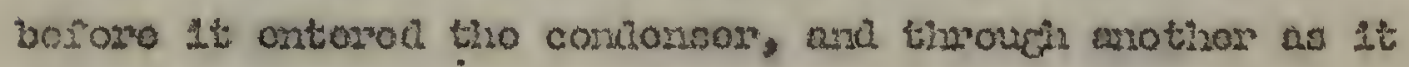
Lort the comioneor:

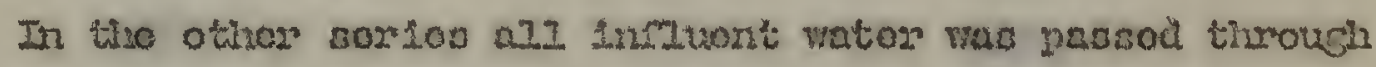

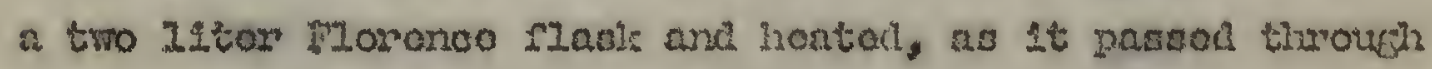

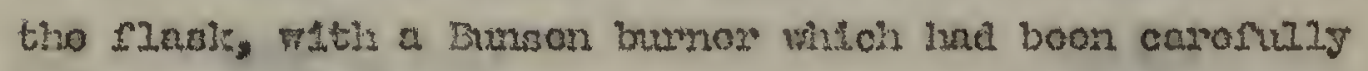
rogulation so tho water was warnod to a robonably uncorm tomporaturo. The tomporaturo thus obtatuod varlod from $17^{\circ}$ to $22^{\circ} \mathrm{C}$. Wator rlowod through tho conkonor at around $200 \mathrm{c} .0$.

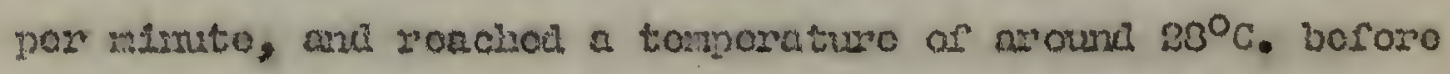
flowing out of tio condonsor. The rosults ninted in trole 4 aro surficiont to indicato that thono is no asfraronco botwon

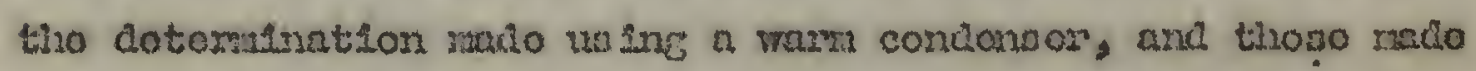

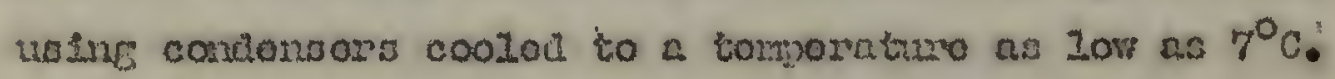




\section{2aive 4}

If foct of Contonsor Natar Iormemctiuro on tizo Mroiygis os Iact 1c Ac20.

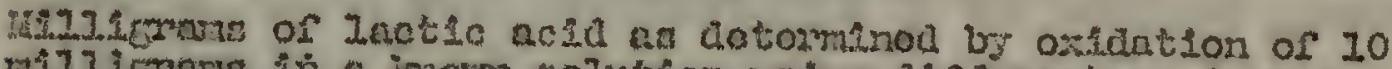
wilingand in ionow solution us ing dirforant condanso: tomoratizos.

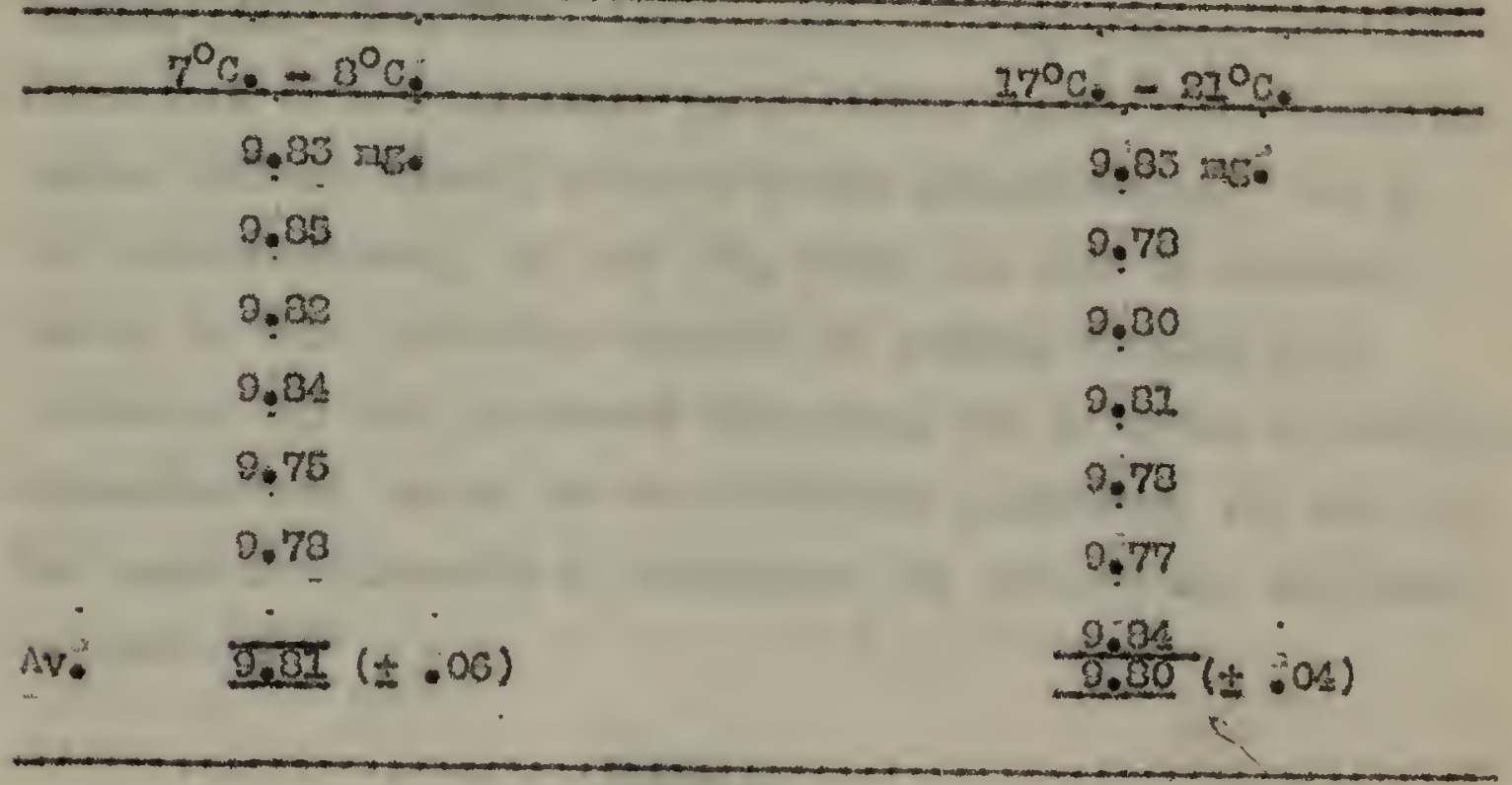

Frictomarr and ornosor (3D) dil not indicato at what

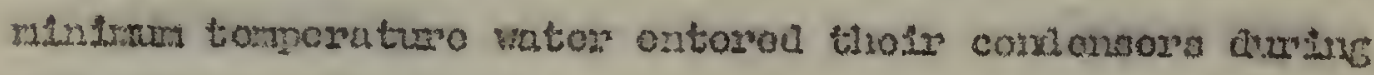

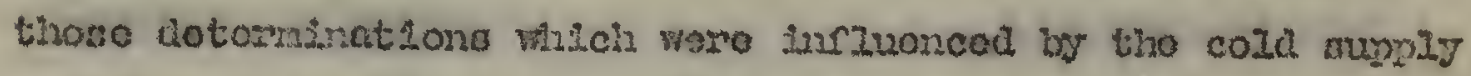

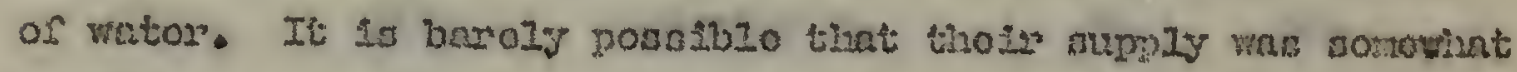

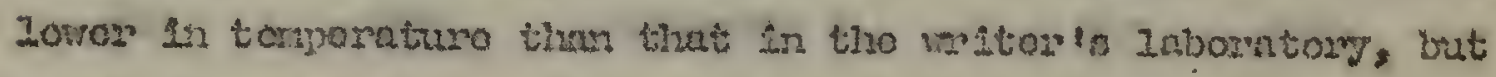

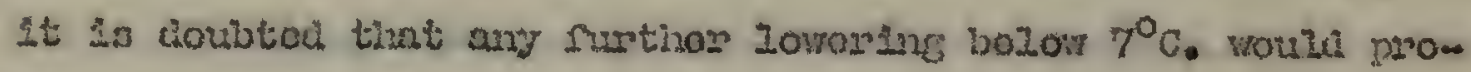
duce roouzts that are any aisforont than those printod in tablo 4. It Is to bo concindol, tixoroforo, from tro eviluonco at

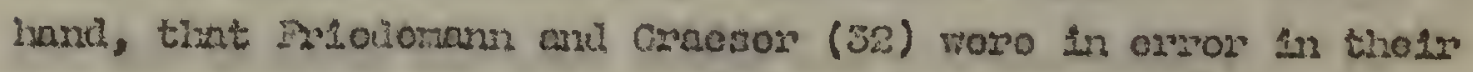

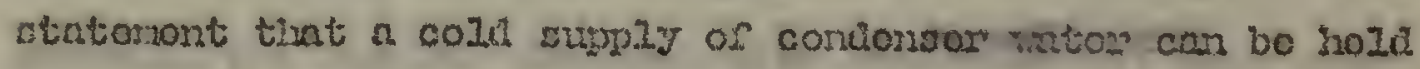
rosponsabio for. IOW rosizts In dotominations, us ins tho aoratLon procacturo: 


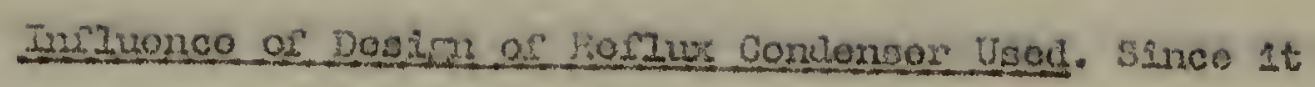
was round tinat the tompereture of the wator ortering bivo

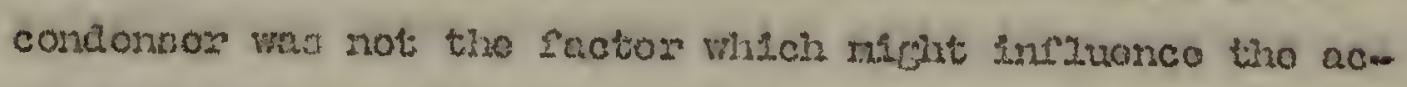

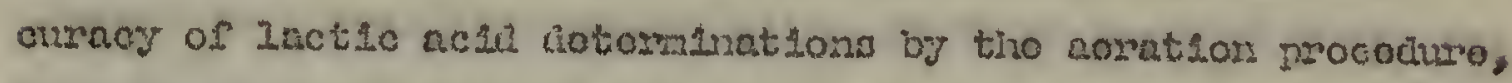

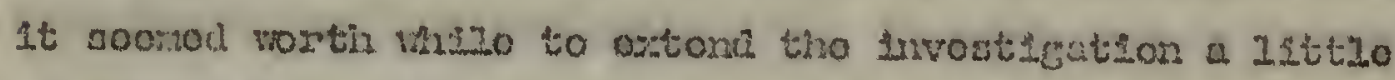
Ruring along tilia 1 ino, and to dotormino whothor or not tho

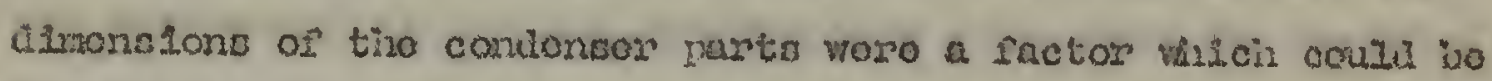
varica vitinout haminu orfocts on the dotomination. One of tio two condonsorn, (A) and (B), which hat boon in conitant uso up to this polnt ves roplacod by anotiron lioplese typo condoneor (G) with derforont dinonsions and a sontos of parnliol

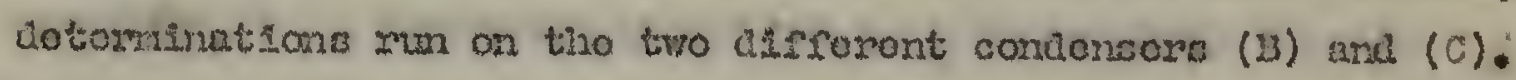
2320 osinct matrutenonta of conicngore (B) and (C) ase Includod 11 tablo 5 .

\section{Saivio 5}

\begin{tabular}{|c|c|c|c|c|}
\hline \multicolumn{2}{|c|}{ arsiala rulu } & & \multicolumn{2}{|c|}{ Tnasco Iubo } \\
\hline Dentotos & Ioxtis. & & Dinnotor & Iencins \\
\hline 31 & 255 & Condossor $\mathrm{B}$. & 25 & 245 \\
\hline 55 & 200 & Condonson $\mathrm{C}$. & 20 & .255 \\
\hline
\end{tabular}

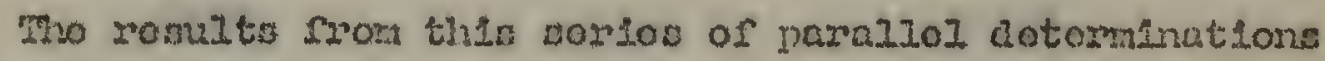
sivom in tabio o indicato that condonsors sinilar in dosien to (B) nro probably tiso noro nultol for tio bost resultis. Ir conornz, the rooults ostainod with condonoor (C) 2xoro moro

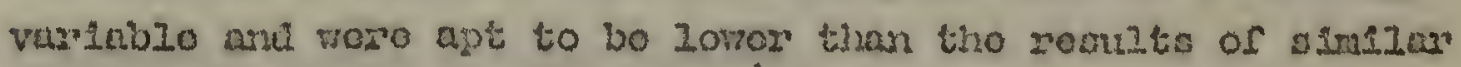

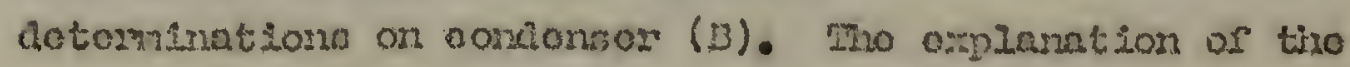




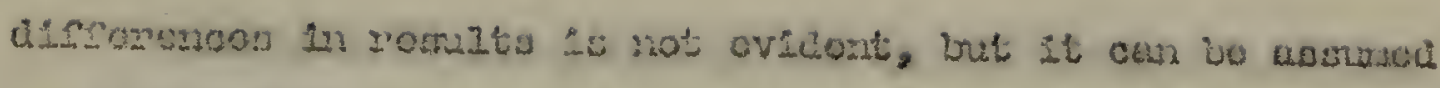

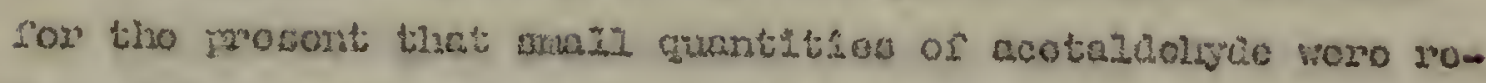

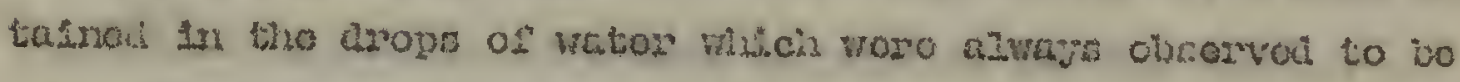
prosont as a rowult of concionsation of wutor rapor over tho can

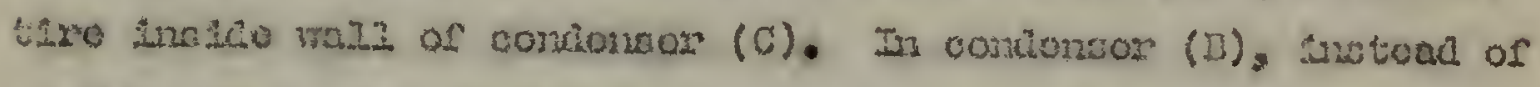

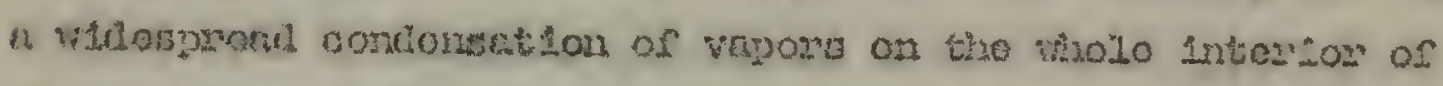

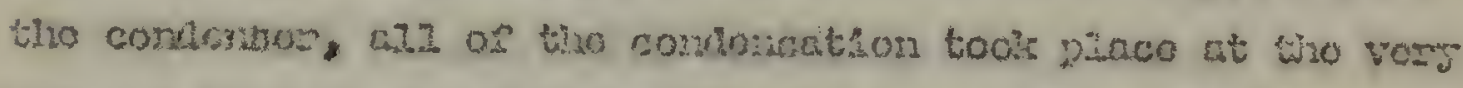

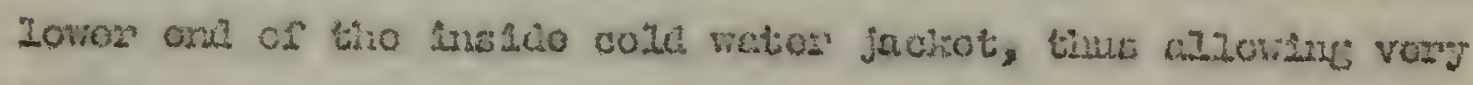

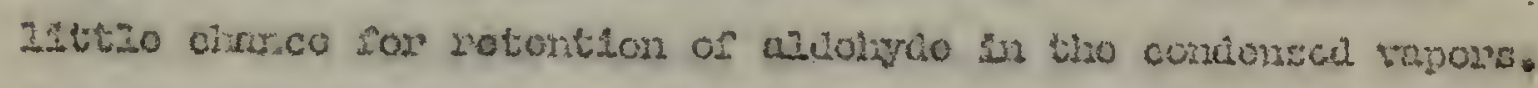

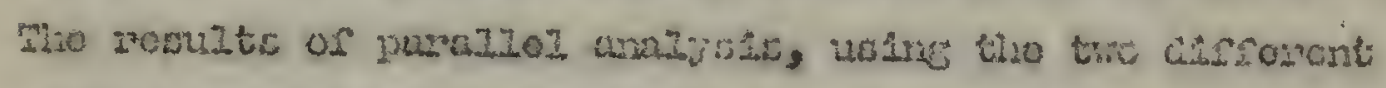

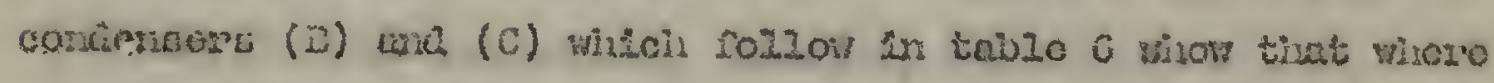

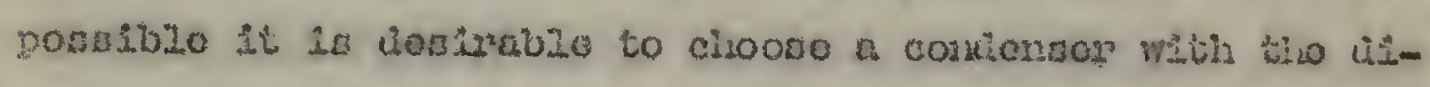

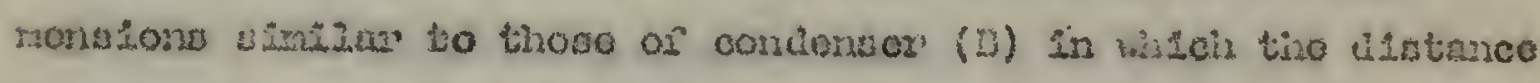

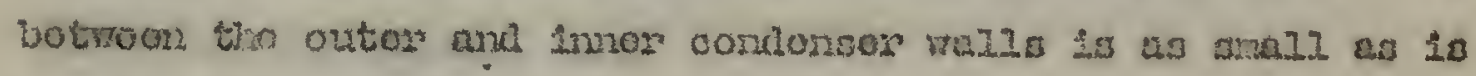

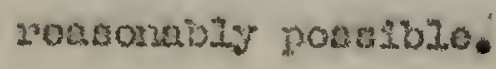

\section{6}

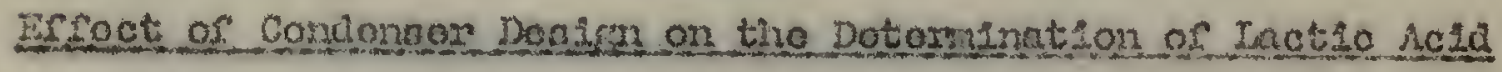

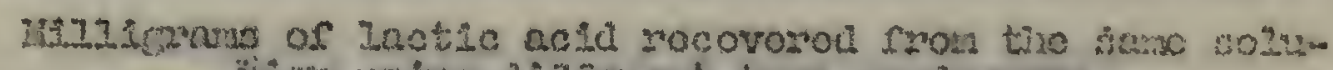

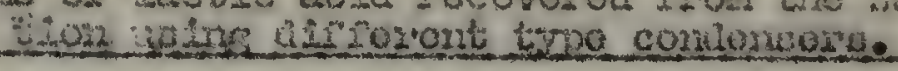

\begin{tabular}{|c|c|c|}
\hline \multicolumn{2}{|c|}{ Conconson 3} & Conquaros C \\
\hline & 3.37 .26 & $0.50 \mathrm{me}$ \\
\hline & $3: 10$ & 3.30 \\
\hline & 0.50 & 0.40 \\
\hline & 0.40 & 0.18 \\
\hline AVOIECOOS & [..33 (1. :02) & $0.35(1.14)$ \\
\hline
\end{tabular}

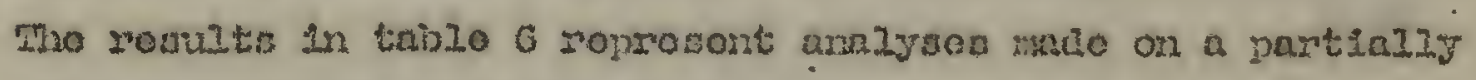
docomposou narplo of aluo lactato. 


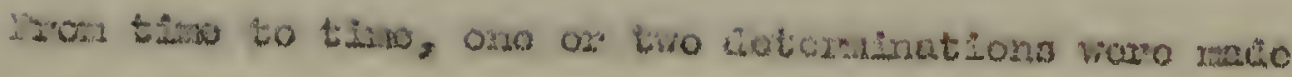

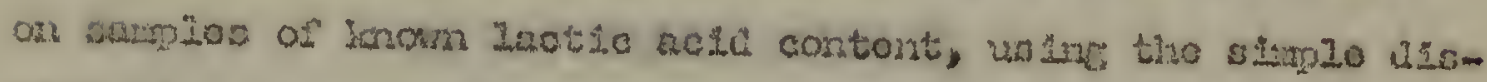

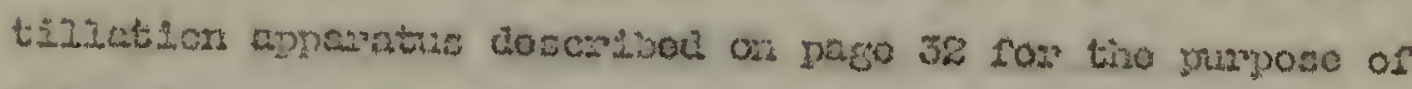

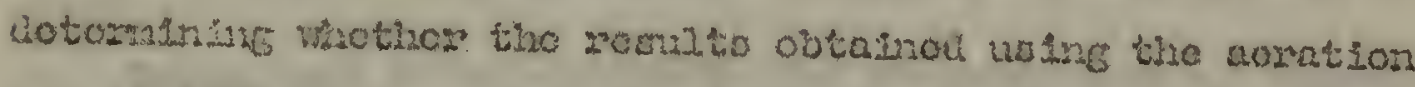

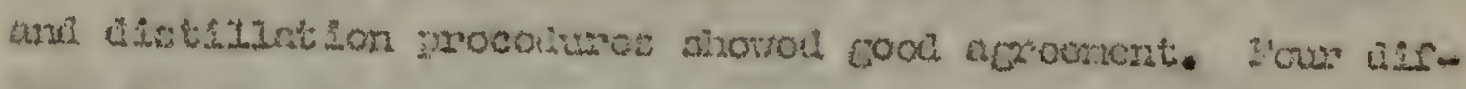

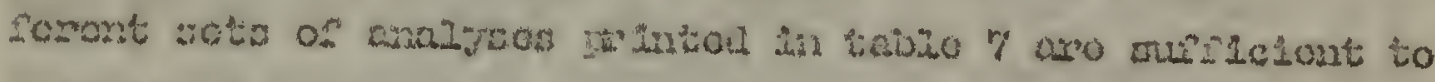

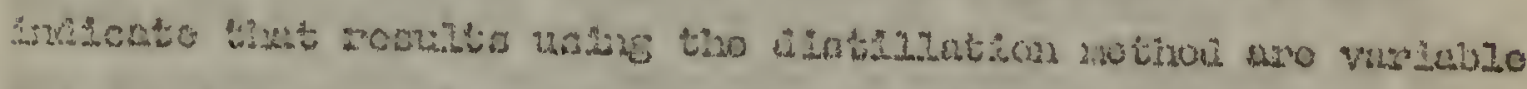

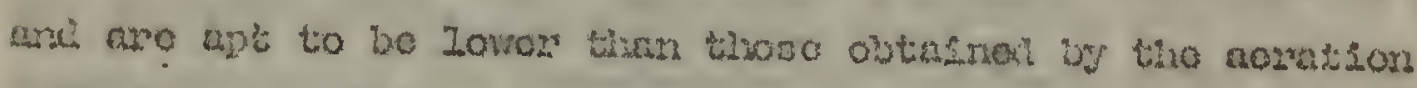
mothot. As montionod bofore, tho anformen nar bo tuo to tho ueo of impropor teclunquo in tho operntion of acro dotwin in

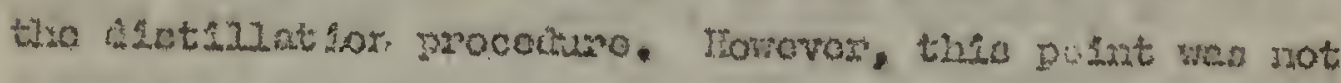

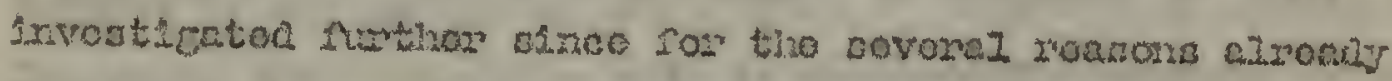

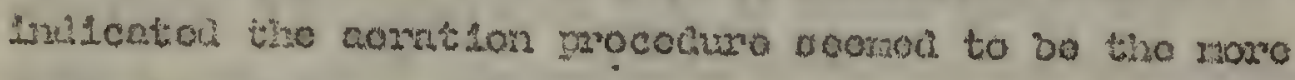
low froble sos iteneral uro.

\section{arision}

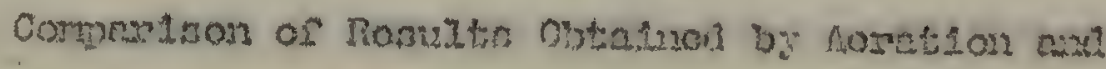
Dotiulation prooedureo

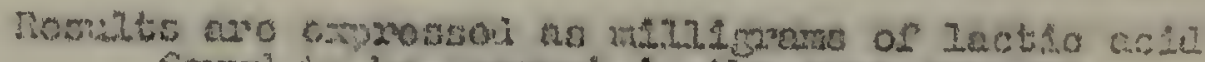

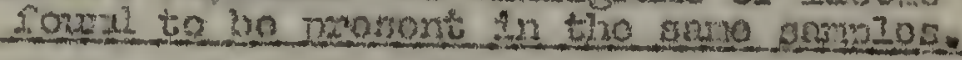

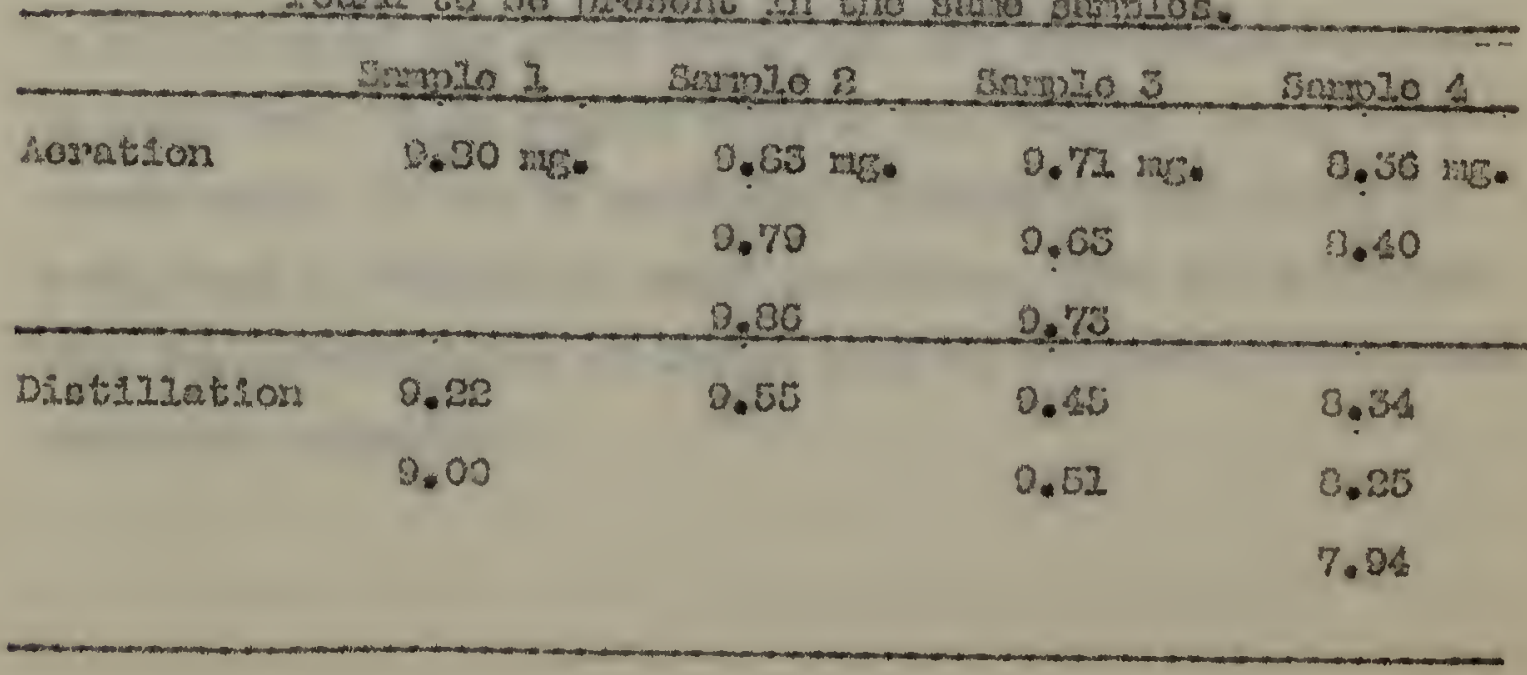




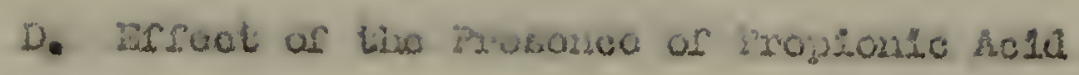

in tixe Dotomatination of Incto Acese?

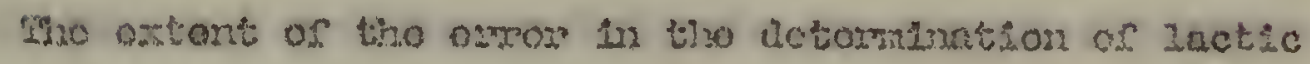
acle che to tho prosenco of a number of other cormounds was

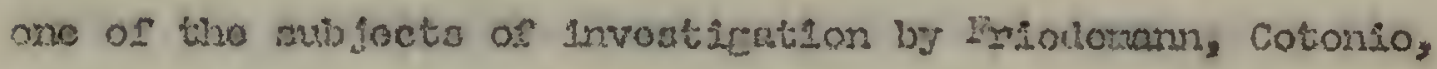
and schasfer (20). Finoy hawo mado no nontion, howovor, of on

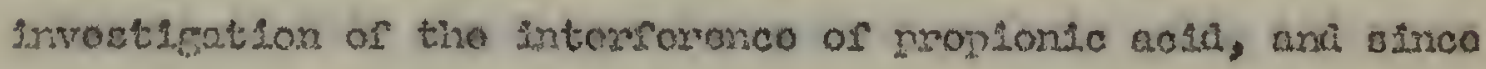
it. A. posasolo for this nete to bo pronent in acmo of tho povio brinos to bo annlgzod, it wac nocescary to ontablish

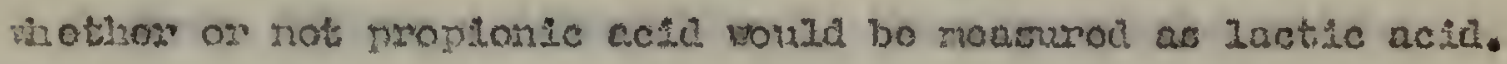

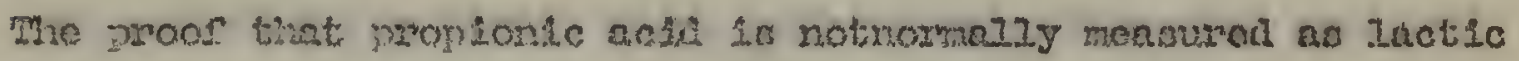

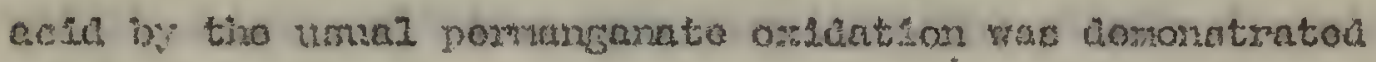

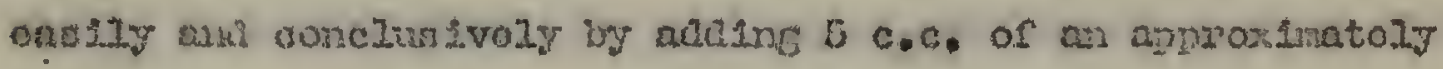

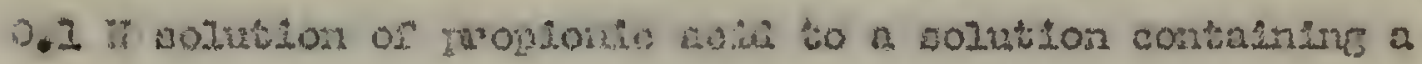

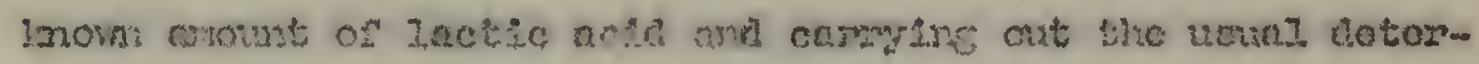

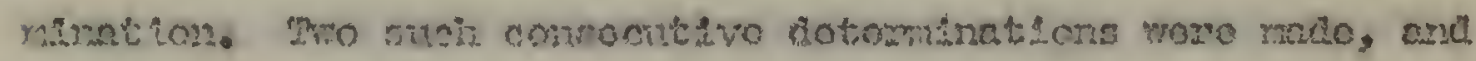

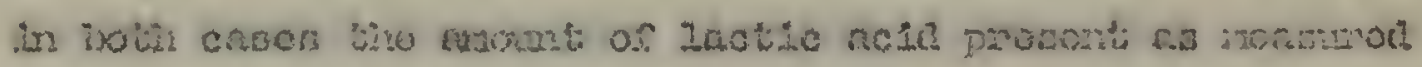

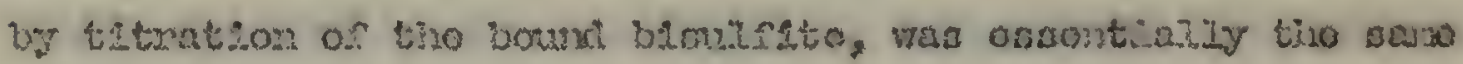

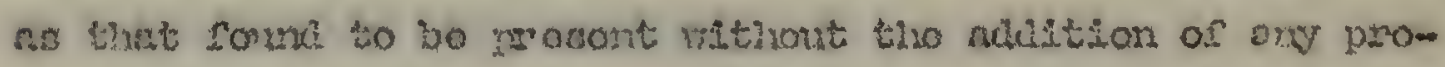
yonlc ackl. It cas bo concluter, thoroforo, that proplonlc actl, ovon in rolativaly lere quartitios, loos not interforo

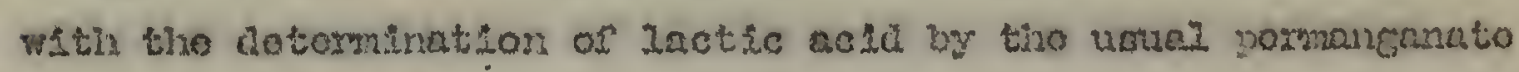
oridation procoluxo. 


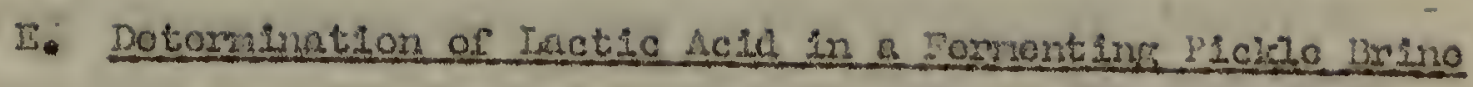

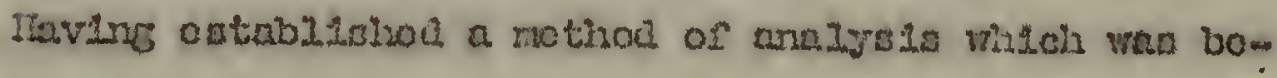
110ved to bo vory nocusy anocirle ror tho lactato malcal, tho writor wo in a position to dotorsino tho amount of lactic acsc

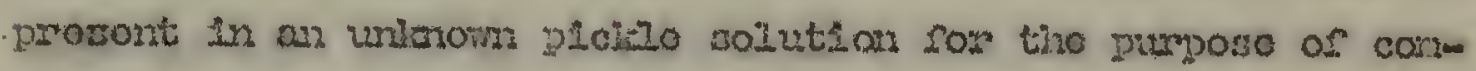
paring tho rowutes this obtalnod vith those obtalnod by th-

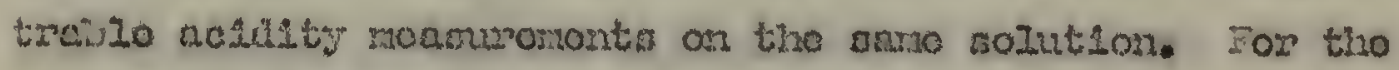
murposos of this campardan tho writos analysol mino atfropont

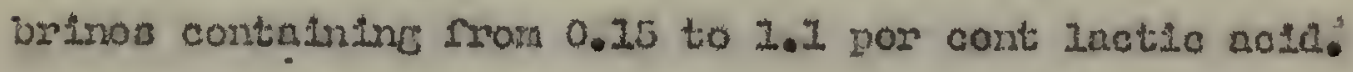

1. Dozcript1on of tho sarm Iog Anazyzal

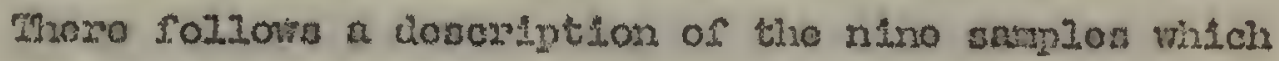
woro ans.lywod for anctic acja, both by istration vith atandard

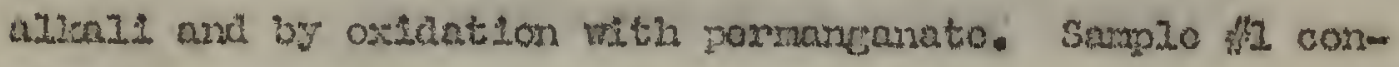

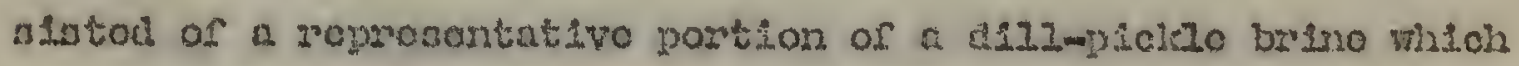
had boen hell at a comporatura slifinty abovo frooming for sovezof nontise following fomontation. Yoast nicrociona and

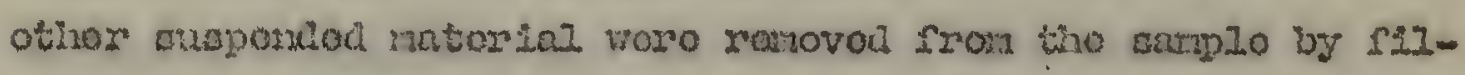

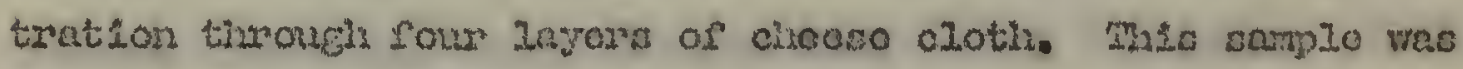

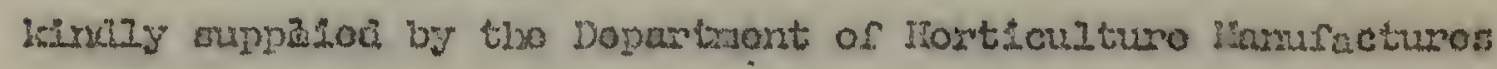
at laseachuotes sute Colzogo:

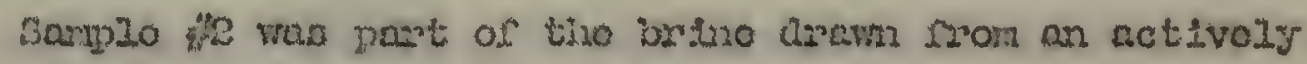

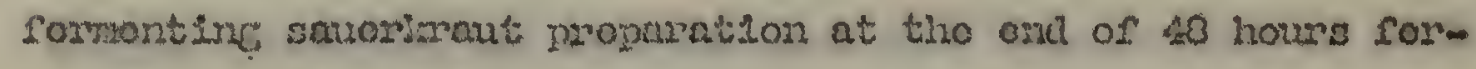

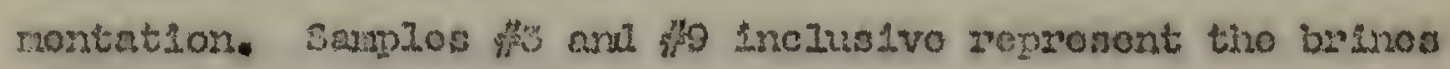

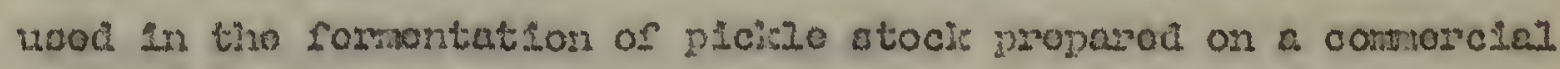

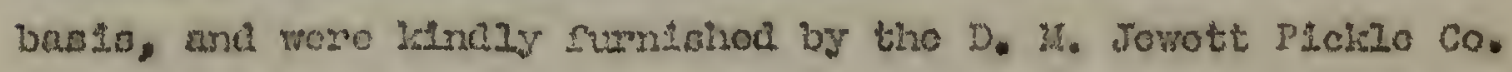

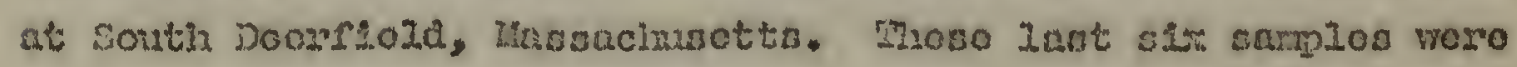


Gram Iron coverul Iargo noodon formontating vats twolvo or maro foot in diarator at a polnt about ono or two foct bolow the sursaco of the Ifruis in tho vat, with the oxcoption of

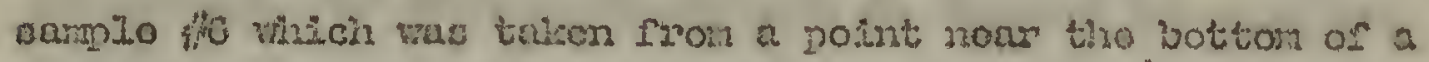
vat Ln tho procoss of bolnc oxstiod at tho timo. Al tho

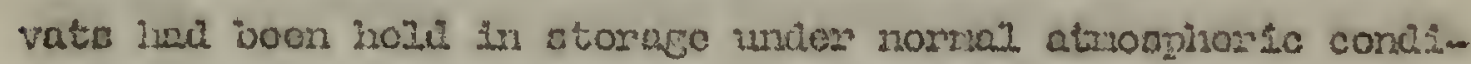

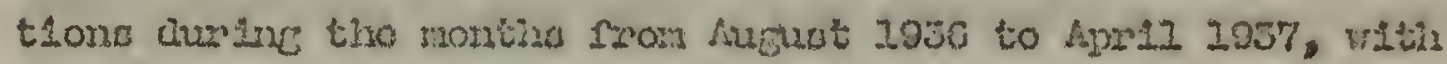

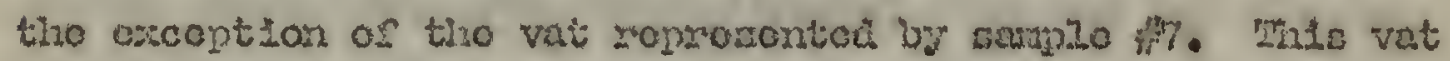

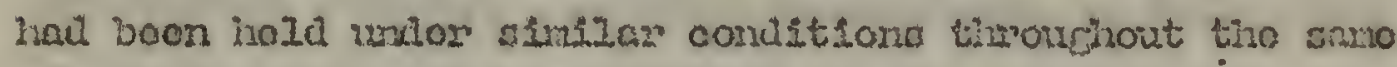
perioh, and for at zoast one yoar provious to that. The vat

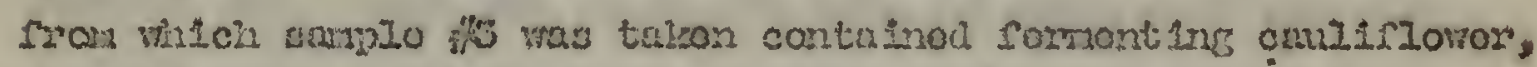
and aII tho rost contulnal formonting oucurivor stock:

\section{Dotorgingtion of ritandio Aclatt}

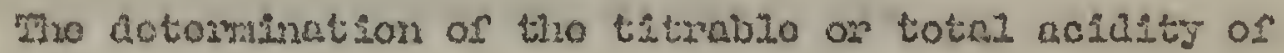

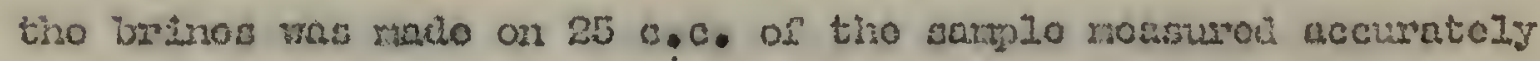

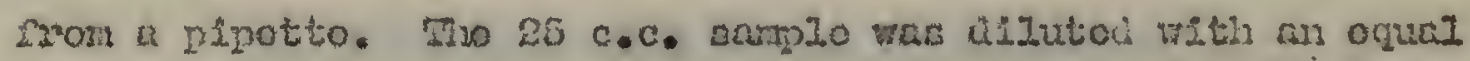

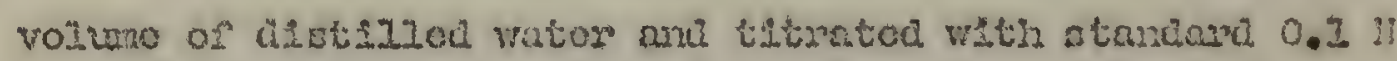

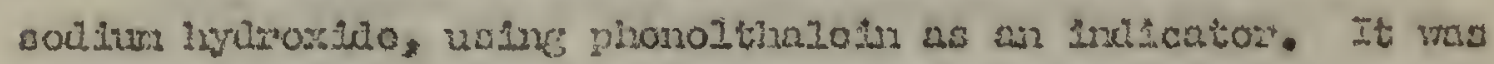

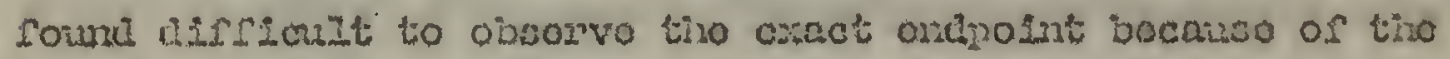
dovolopmont of a yellow color in tho oolution upon tho adution of tho allali. Howover, by carorul aropriso adastion of tho

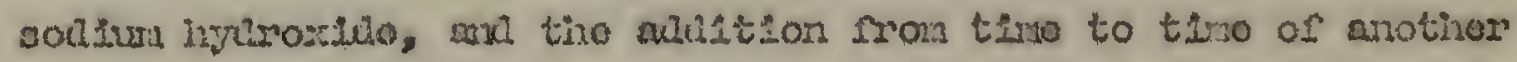

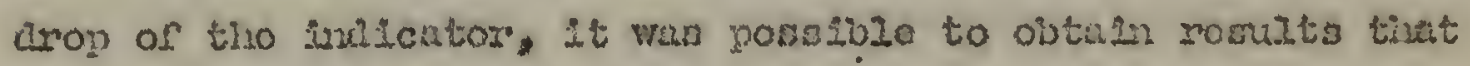
agrood in gonoral wition 1 por cont: 


\section{Dotedzination of Inatic Ac1d by Oxlation}

Tho usual ox Leation procolure, thi Ich has boon deocribod provioualy, vas rado on an ailiguot of ancil of tho arieinal

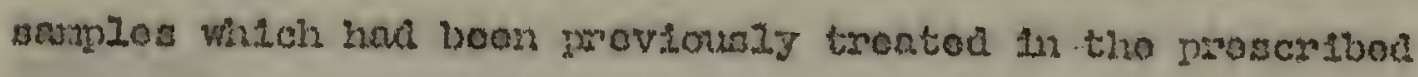

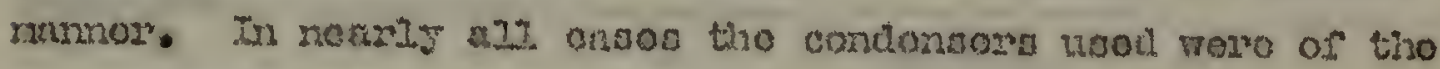
semo dirunelora as combonsor (B) as doscriond on paro 56 and

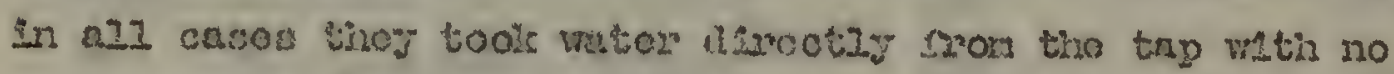

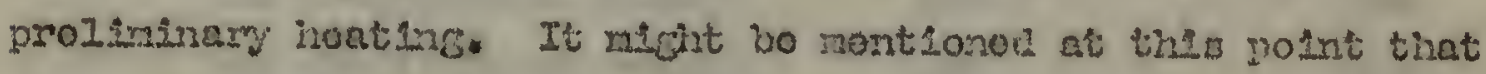
In thaso cares whore a condonoar of tino typo (C) was usod the recults woro gusto apt to bo low and, at bost, ware not cons1oteant with thoso obtainod by usine condaneors of tho typo (3). Mris obvorvation agroos weth that rodo before, usins

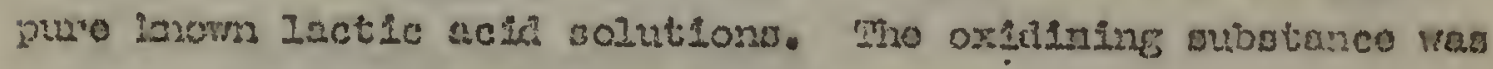
0.037 potass ium pemangarato in 011 casos.

1. Comparison of Fitrablo Ac1d1ty iloasuromonts With The Rosurto obtalnoa by ariciation.

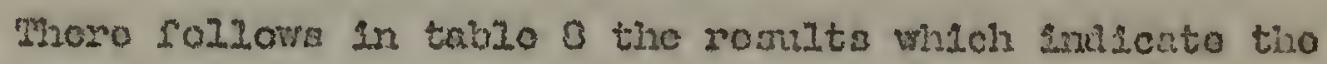
arownt of lactio acli in wio niro whinom picielo urinog accordIuf to t1trablo acidity monsurononts and according to tho dotormination bs oxiatition. 


\section{0}

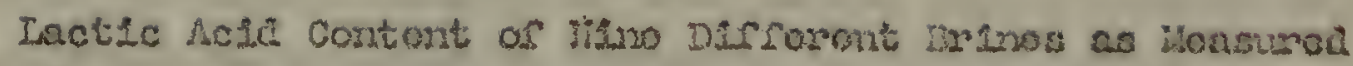

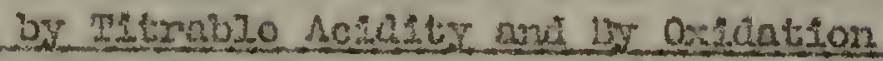

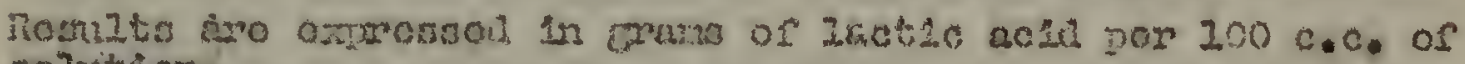
solnition.

\section{MEtrablo}

Ac ilitex

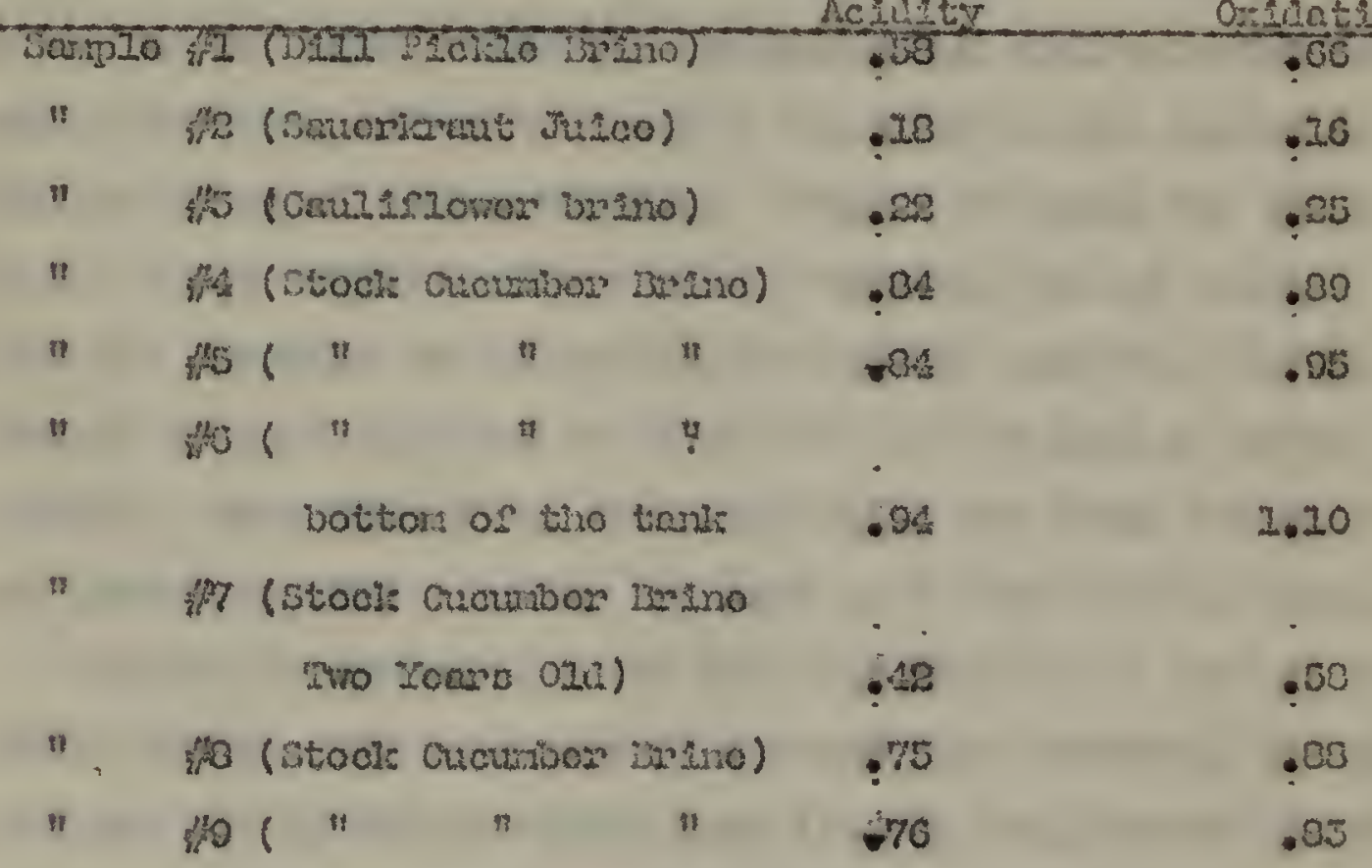

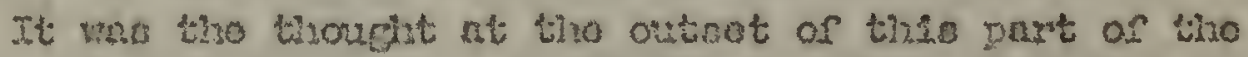

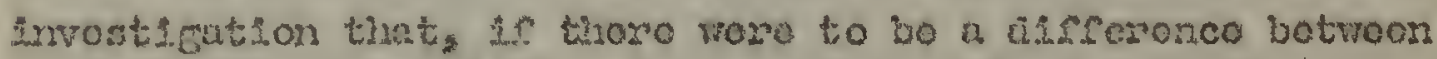

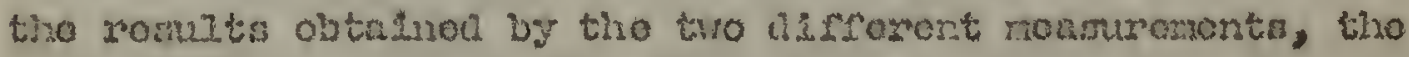

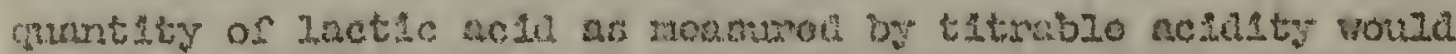

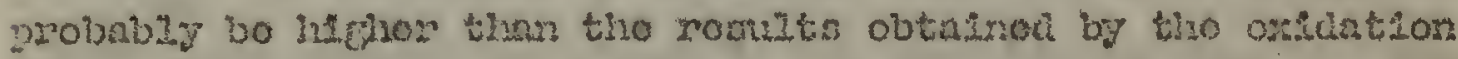

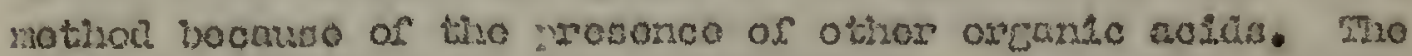

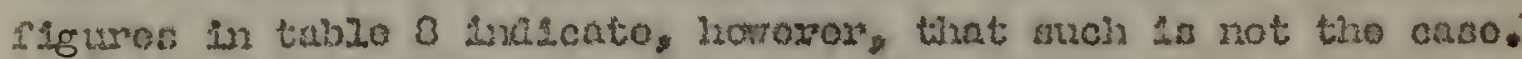

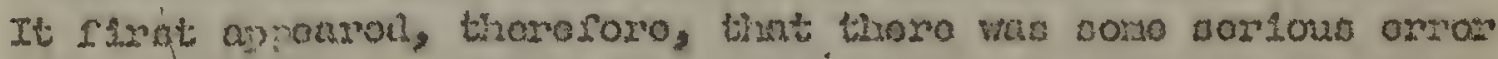

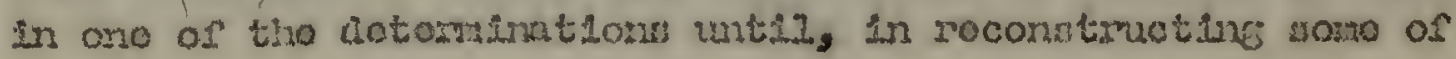




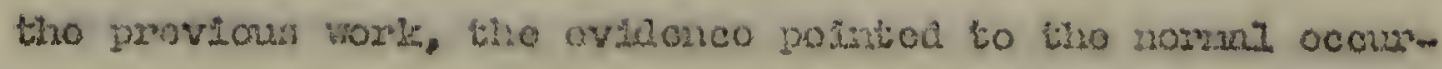

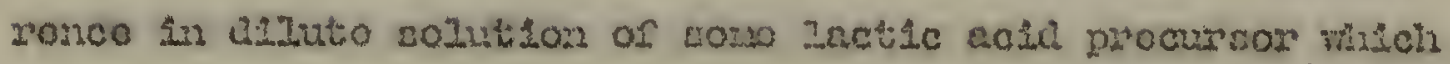

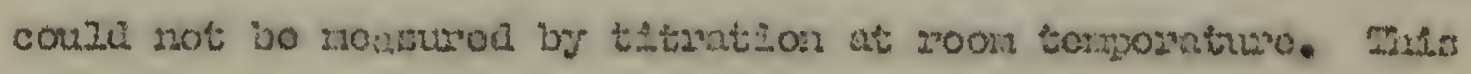

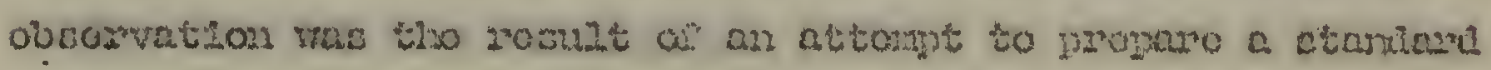

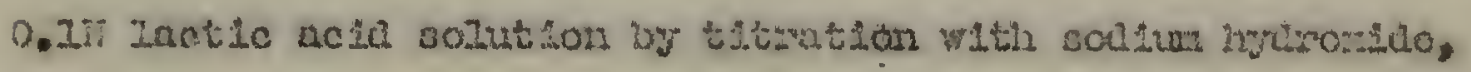

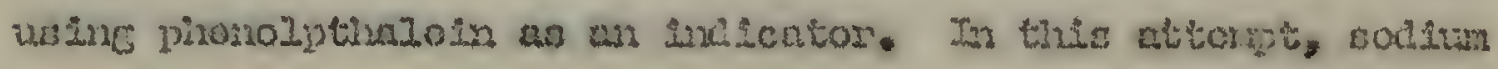

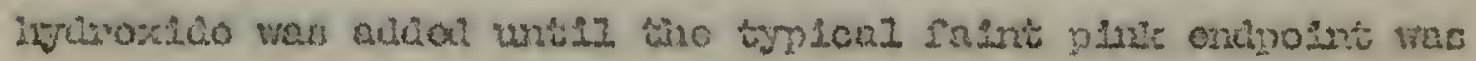

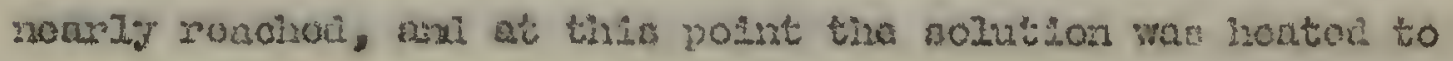

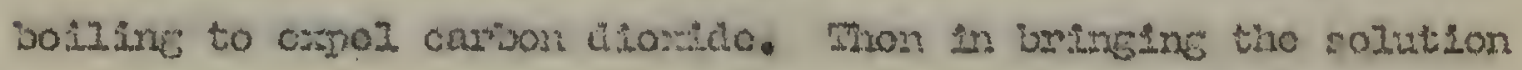

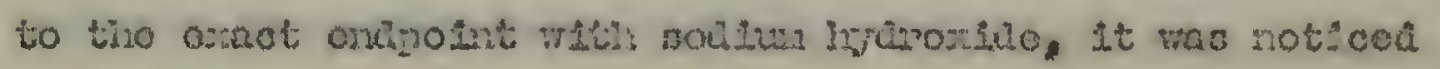

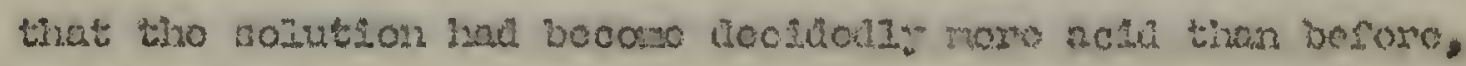

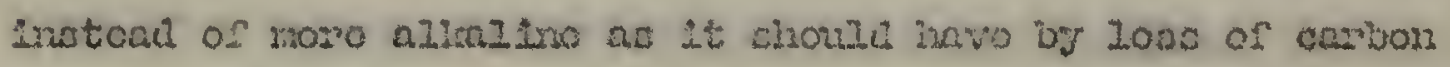

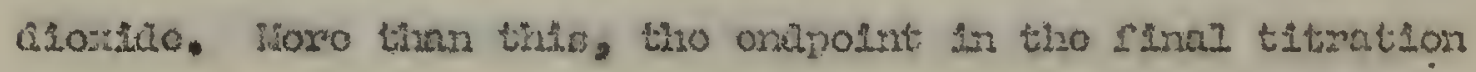

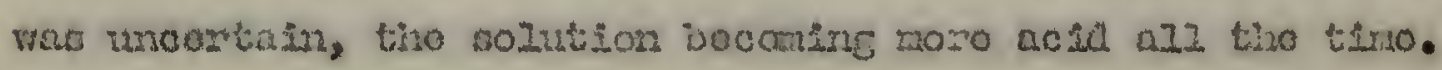

Letor, Is dotorintulue tho tstrablo acillty of somo of tho

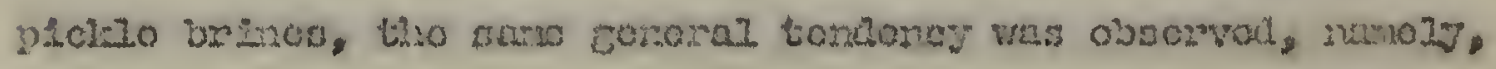

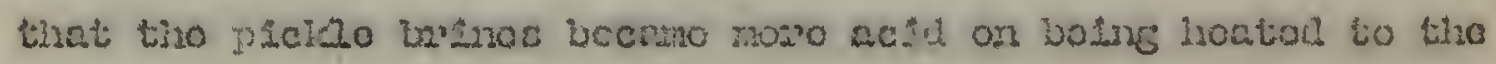

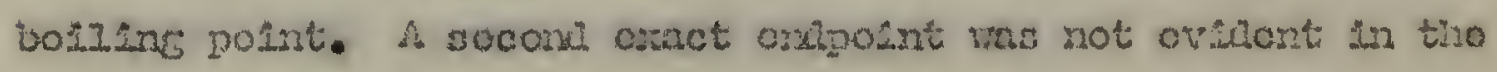

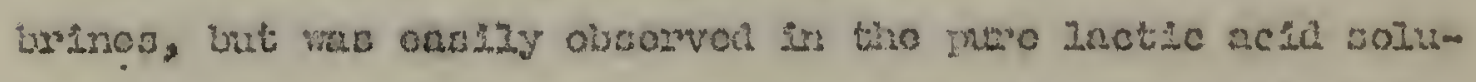

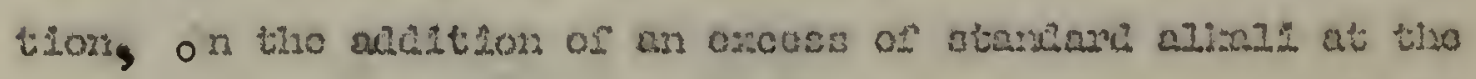

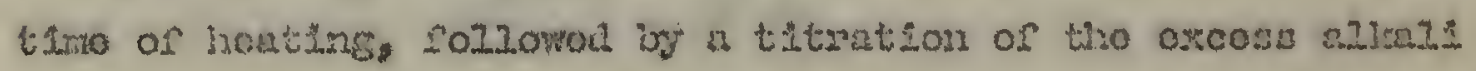

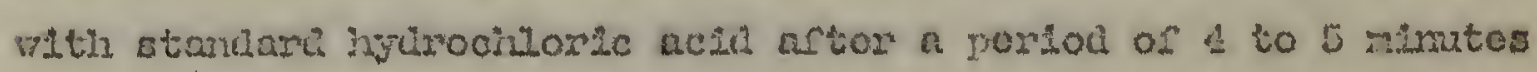

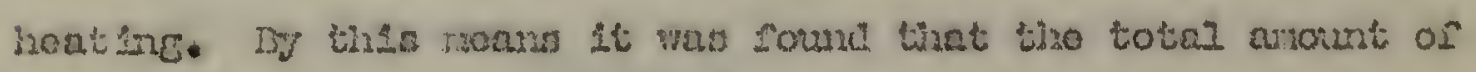

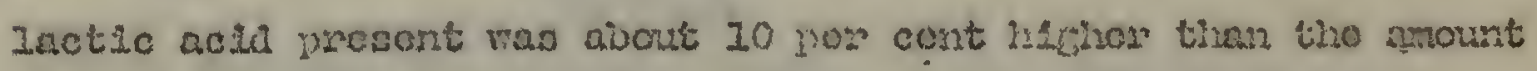

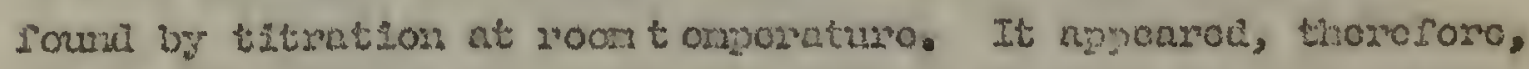

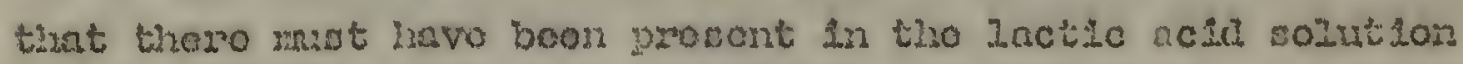
como procurnor or lactic acil milich could bo titintod as laotic 


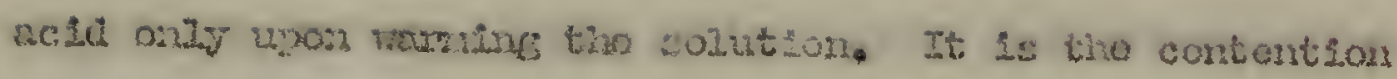

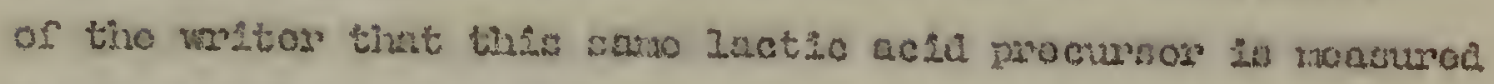

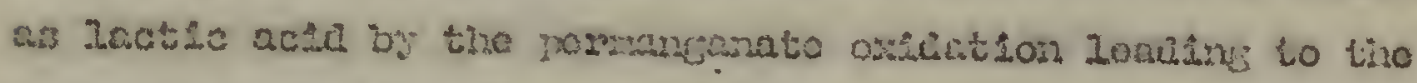
wituror zromitis by tiat mothou.

mo sact thet lactic ackl in winos nay not all bo in tio

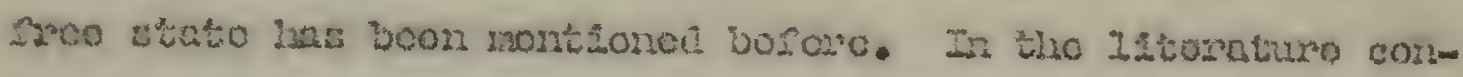

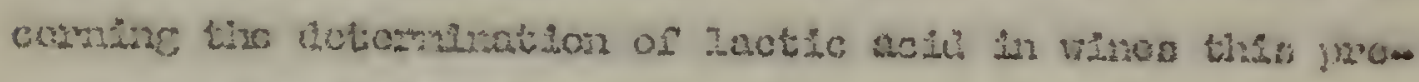

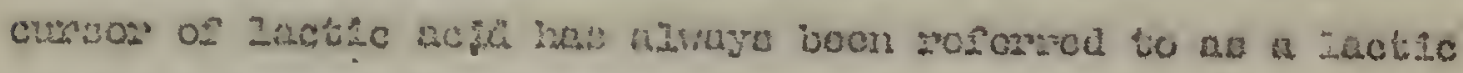

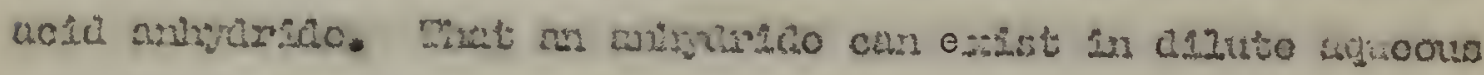

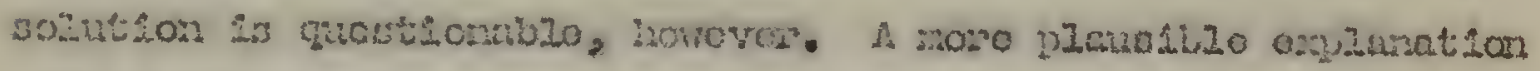

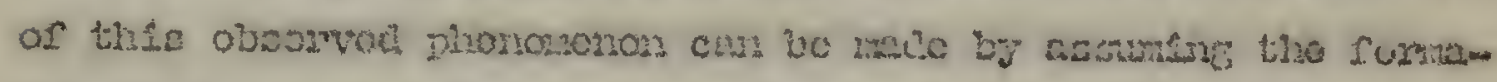

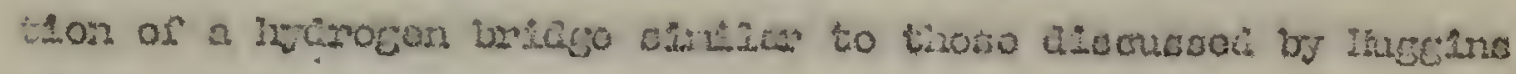

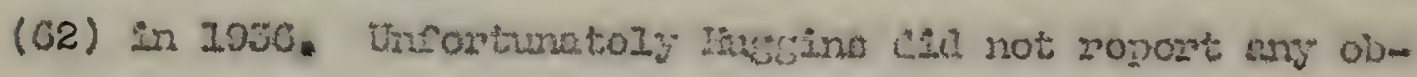

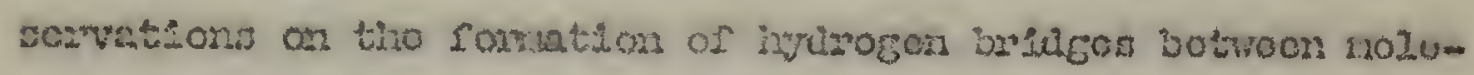

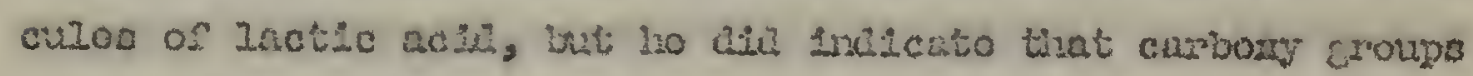

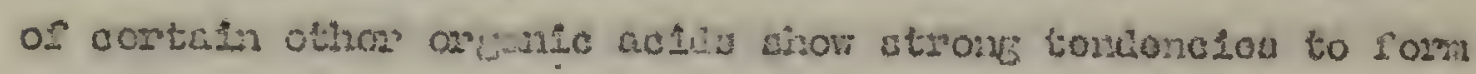

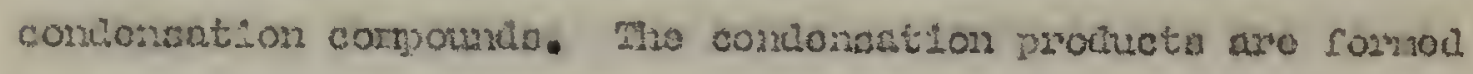
ce whom by tho conoras fomaina solow:

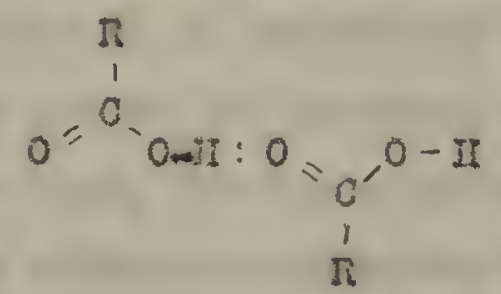

\section{Fy) 2.}

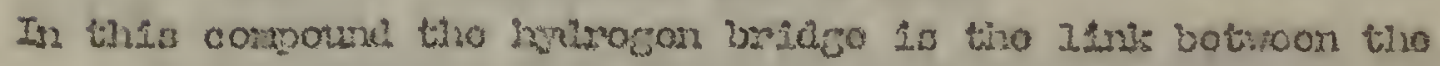

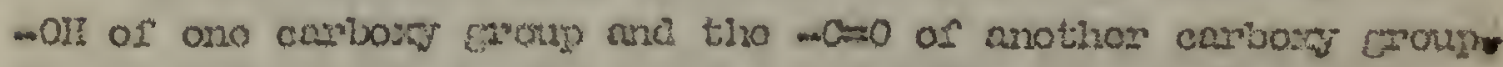

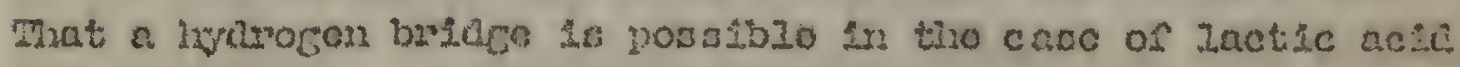
In s.moor solution to onty apoculativo, but is mucin a Inisnco 


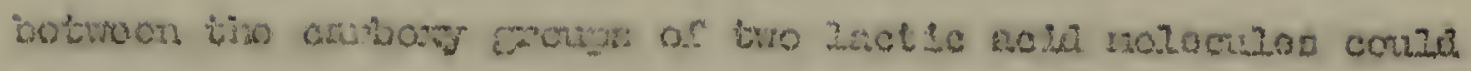

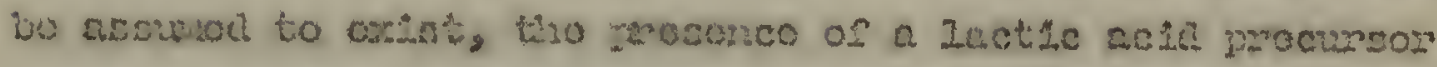

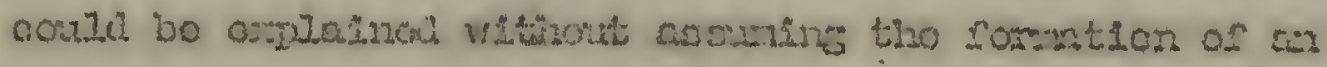

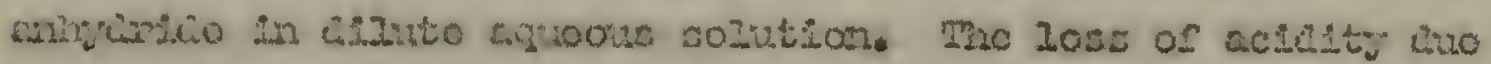

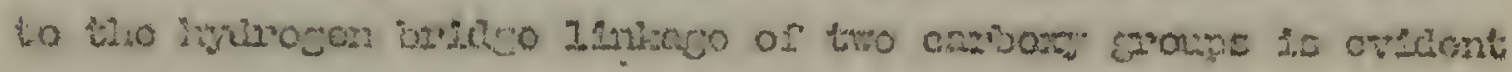

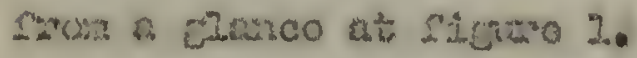

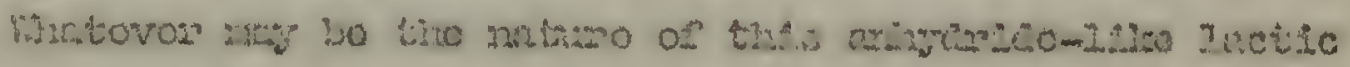

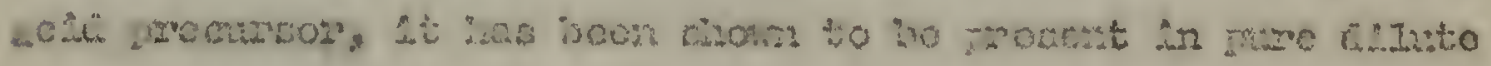

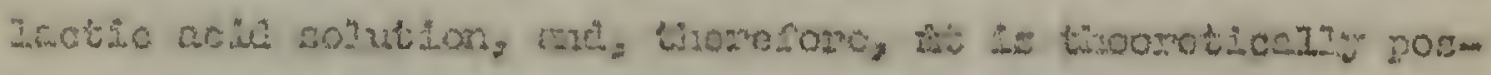

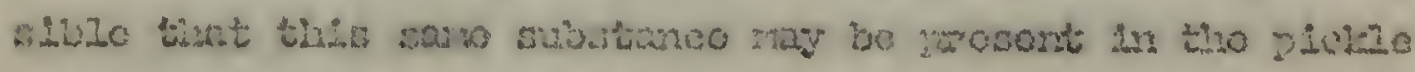

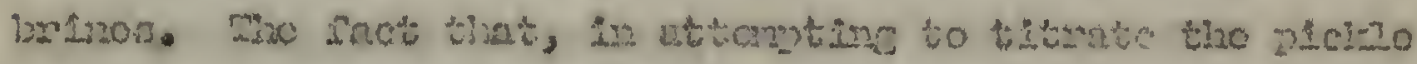

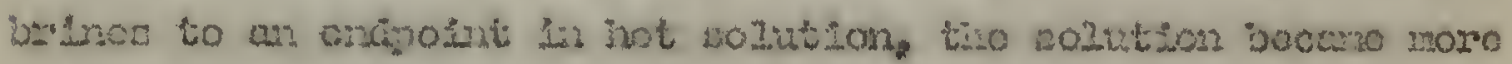

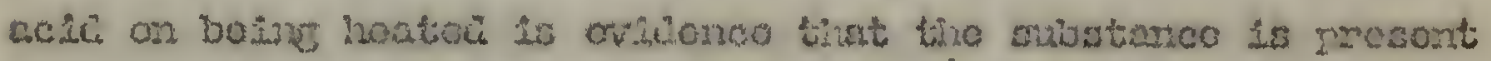

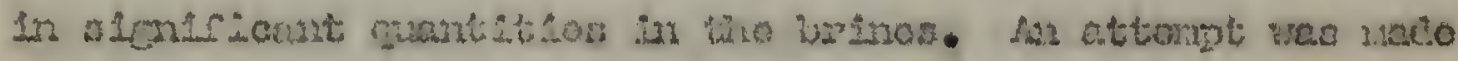

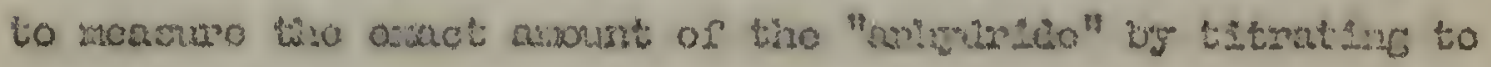

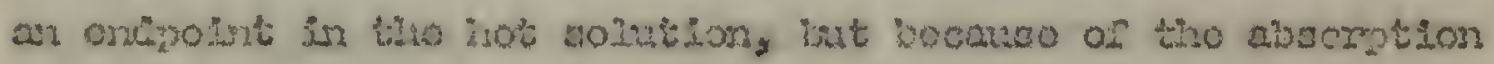

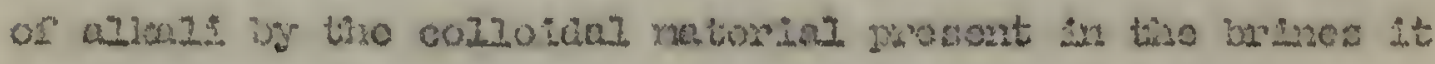

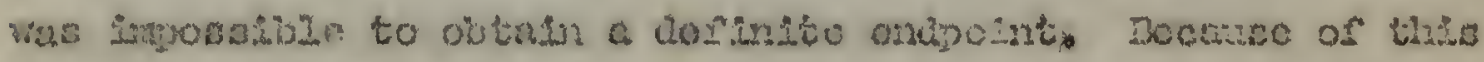

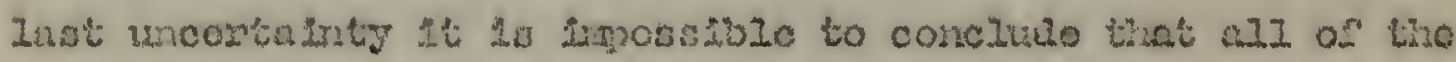

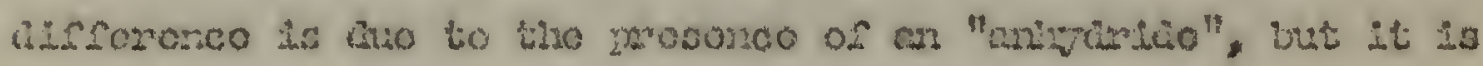

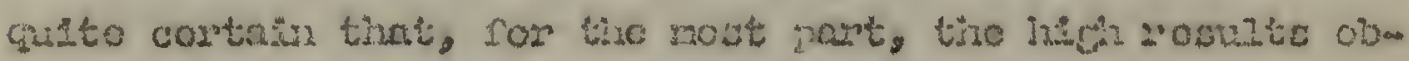

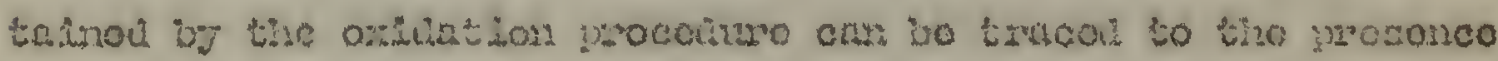

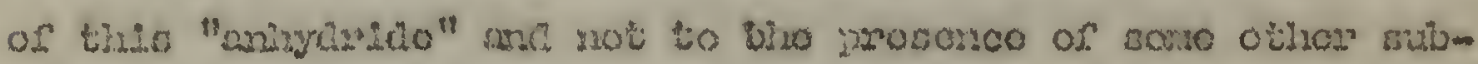

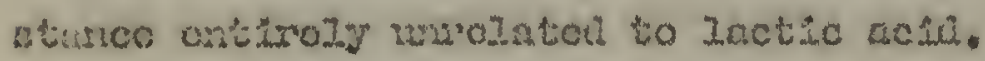

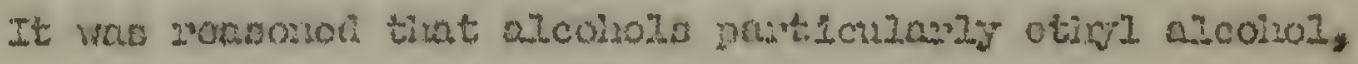

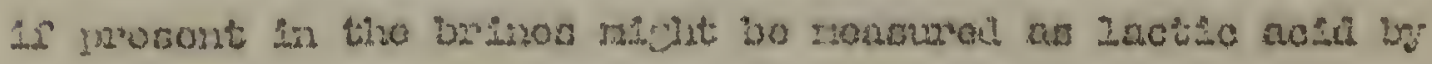

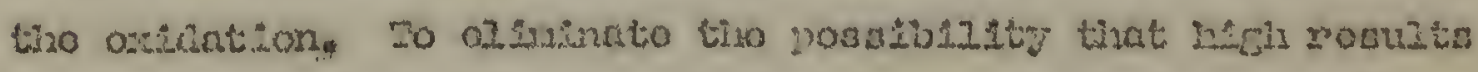

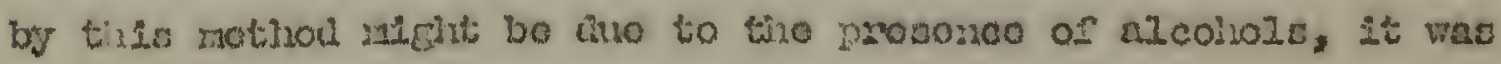




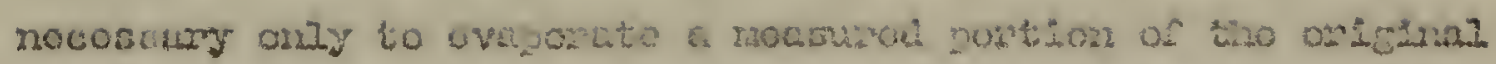

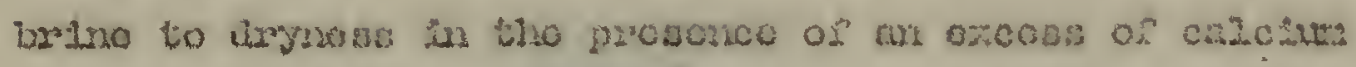

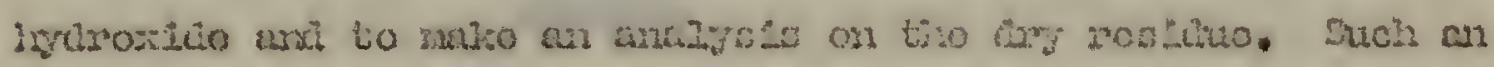

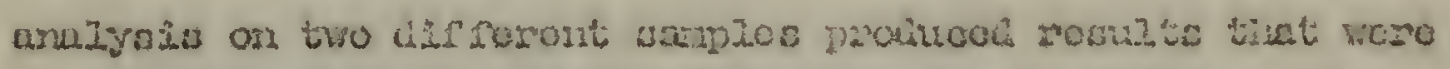

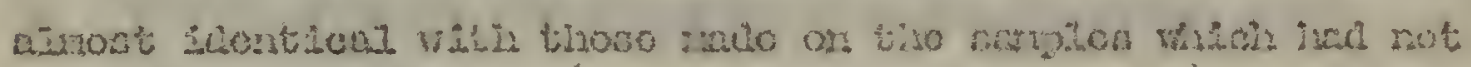

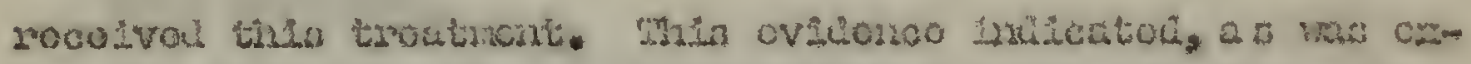

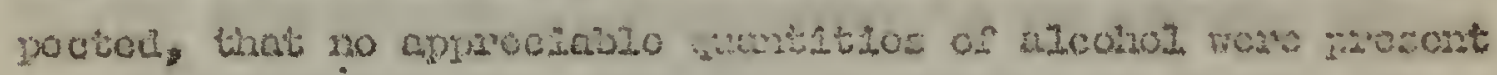

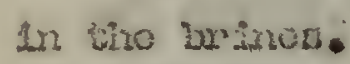

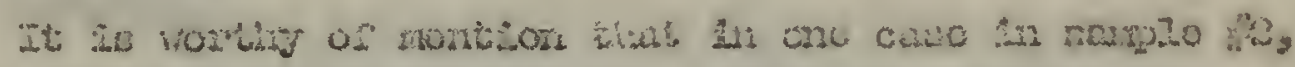

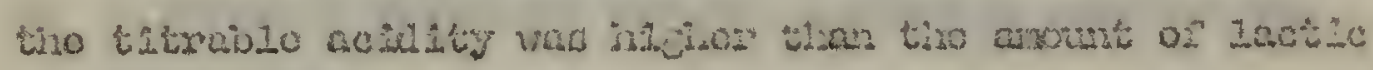

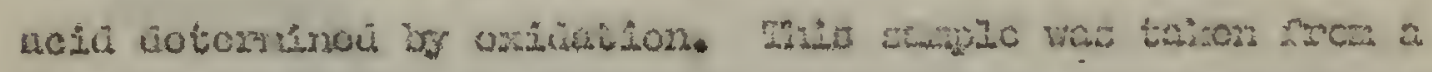

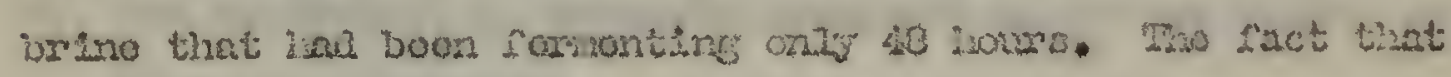

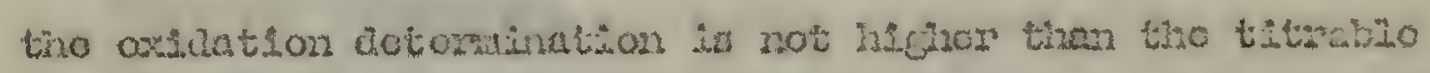

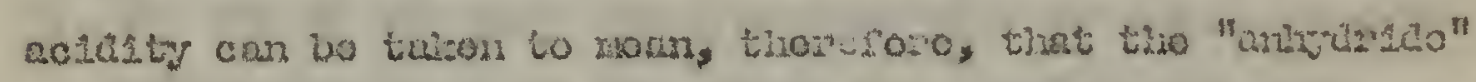

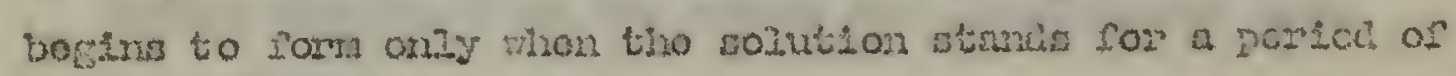

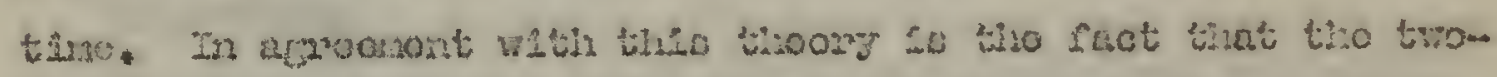

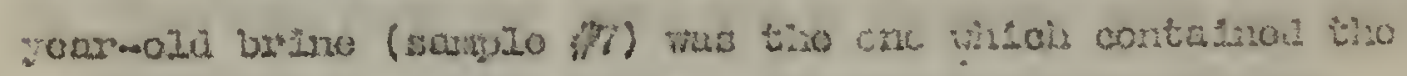
zarcost retio of anisuriato to noo acka. 


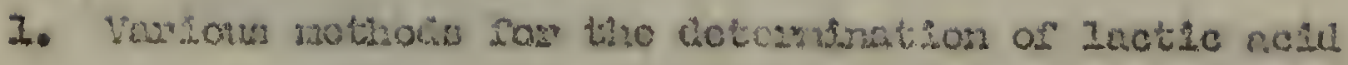
WoI0 roviowed.

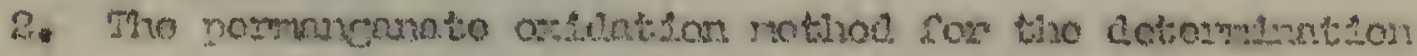

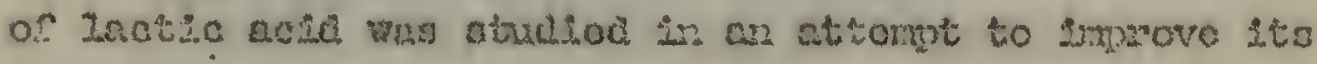
acourang.

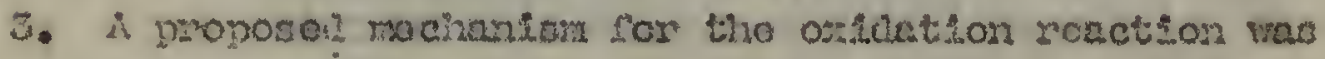
coocribod.

4. Tho occurronco of mangenhe fluosphato in tho oxidut lon reaction bas acmocol:

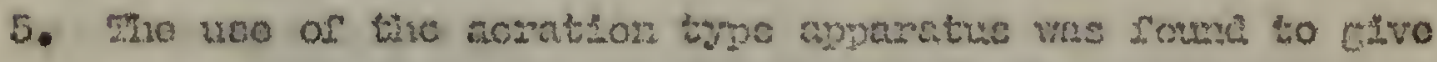
Dottor romite than the uso of tho alditization typo ayporatios.

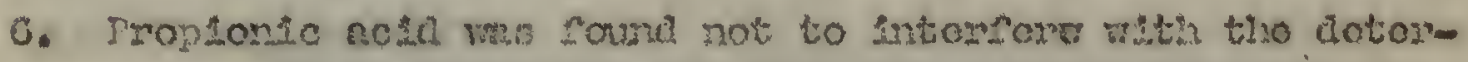

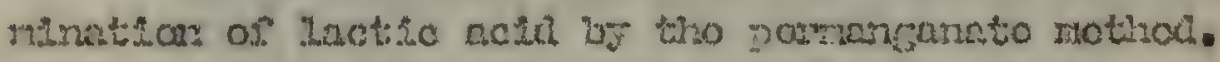

7. Tho twount or Inctic nedt ryosont in a norios of roprom

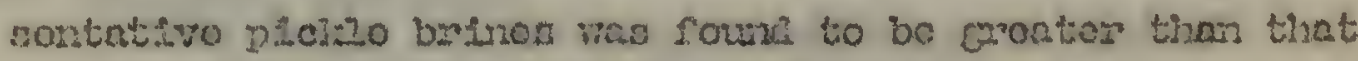

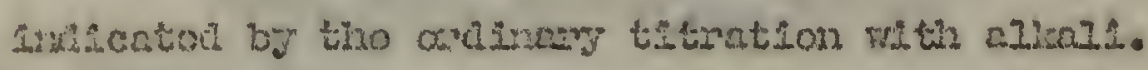

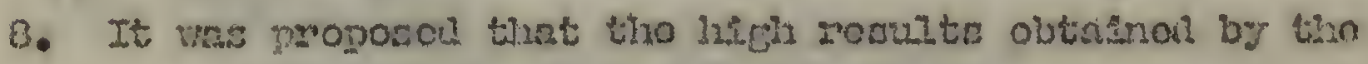

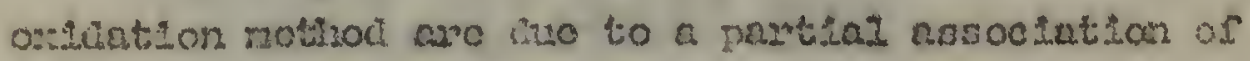
Inctsc acto moloculos dicis tat a.l7 tho 2notic actel provont Its not tetrabzo weth alix.la. 
(1) Losingror, 17

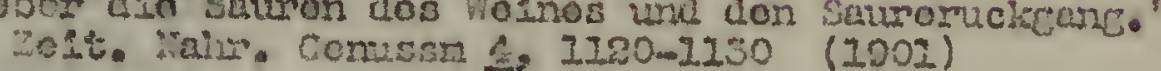

(a) Moettcon, Thoodoro:

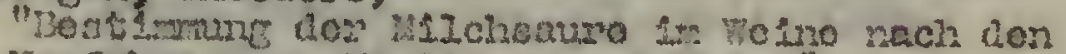

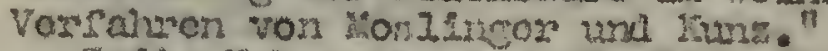
Zo1t. Malus. Comasr 24, 113 (1012)

(3) Daragiola, V. and schippl1, 0.;

"Dto Bestinnane dex inchsurso in Woine rach

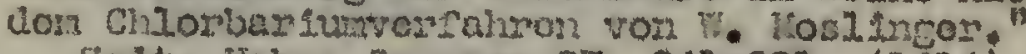

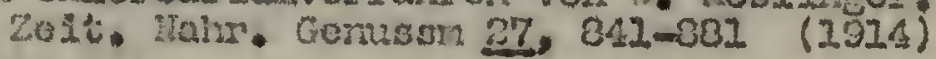

(4) Roottgon, Tizeodoro:

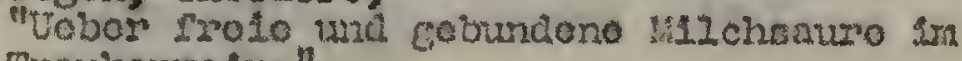

Traubervo. 1 . "

Zolt. Hain. Genussn 30, 204-290 (1015)

(5) Gaverint, A.:

"Tine fuantitativo Dotermination of Lactic AcLid in Staz. sper. agras. 1taI. 17, 752-773 C.A. 2, 1655

(c) Tuns, Ruloir:

"tobor Vorkomon und Beatiryane cor sflchasuro in "พoมne."

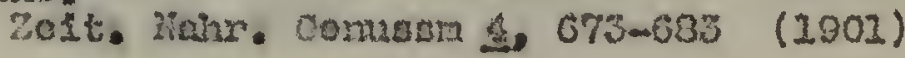

(7) Roottcon, Thealoro;

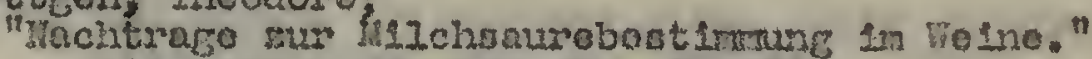
Ze1t. Yahr. domsen $26,437-239$

(8) Nolson, N.R.;

"Dotoction and Dotormination of Inctic Acli in tho Irestonco or Othor Orgenic Ac10.s." $3 . \wedge, 0 . A, C, 2,351-333$ (1926)

(9) mizmans, J. and lioll1, $\Gamma_{0}$;

"Dotermination of Inctic scid in wino by tho stopritration liction."
2. Untorsuch.
Iobonsra $57,525-529$
(2029) C. A. 24, 1700 (1930) 
(10) intery, J.

"Compariaon of tro Iesctio Acla contont of rinos

Aa Dotorratned oy tho step-ritration itotiod ard

by tho Allaininity of "tho Aalx" " IIIt. Loboncm ITE $21,97-90$ (1930) C. . . 14.432

(21) Bontfaxi, G*

"Tho Dotormination of Inatic Acia in Migno." liett. Jobonam. IJ $37,0-14$ (1020) C.A. 20, 2045

(12) Fabro, I.I1, and Dromond, L.;

"Mino Detomination of Iactic Acla in Wino."

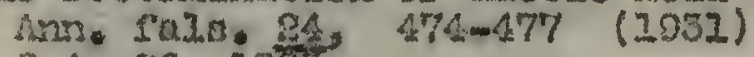
$C \cdot A \cdot 26,1335$

(13) ilicliol, $\mathrm{A}$

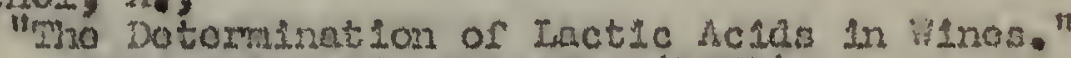
Ann. $50.30 .24,472-174$ (1032) $C . A \cdot 20,1305$

(14) Bores, $P$ and scimzzo, $\mathrm{C}$;

Wotomination of Lactic halu in Mino $1 \mathrm{n}$ tho

Prononce of surar.

I7०11 น. Rovo 12, $433-4.45$ (1031)

C.A. 26. 2374

(15) Bonyogrin, w. asu capt. I.

"Contributson to tho study of some liotioda of

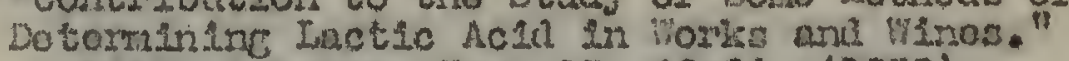
Hit. Lobonar. HyE. 33 , 40-64 (1938) $C \cdot \lambda \cdot 26 * 5170$

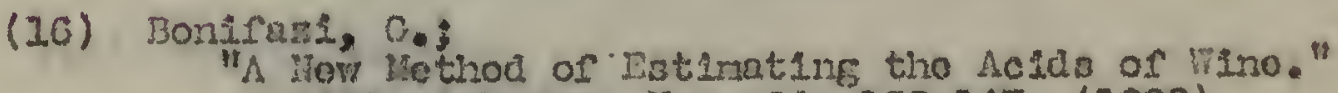
li1t t. Iobonss. ligs. 20, $222-147$ (1929) C.A. 23. 4767

(17) von 20.10nivose, T.

"A Procoda Sor" tho Detorminution of Individual

Acian of Uino - Poscentago Comosition of Conotituonts of Wino end clas."

iste. Lobonam. ITE. 13, 1-15

(1022)

c. 1.. 20. 2382

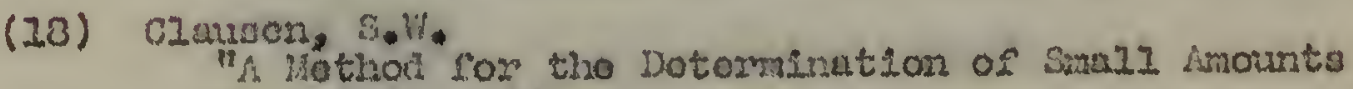
of Istctio Aola.

J. B101. Clicri. 52, 2005 (1822) 
(18) von verth, 0 . and Chamarn, D.;

"Wobor aso quantstrtivo lost1rnune dor M11chsaure dusch Esmptting dor daraus abspaltbaron alcolytanarigo." 310chom. $20,190-200$ (1010)

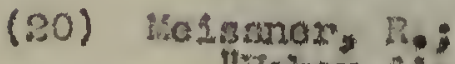

"Vobor the quantitative bottirmung do:

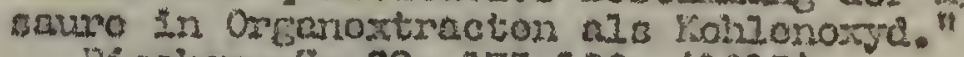
BSochor. $z$. 03 , 175-190 (1015)

(21) Ximpor, Vi:

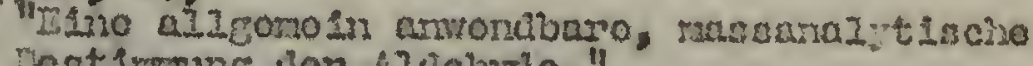
Dont 1renung dor Aliohra.

$$
\begin{aligned}
& \text { Monatsch. Chom. 2J, } 1070 \text { (2900) } \\
& \text { cltod by clauson, 5.W. } \\
& \text { J. B501. Cion. 52, } 203 \text { (1022) }
\end{aligned}
$$

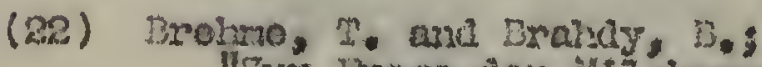

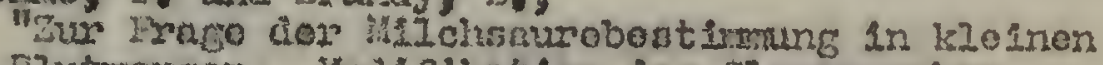

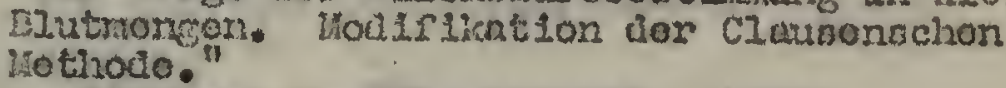

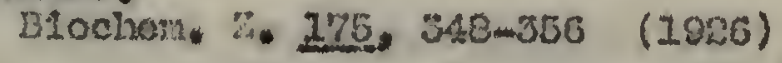

(23) Bong, It:

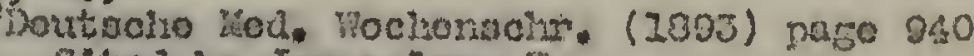

$$
\begin{aligned}
& \text { Cltce by Jomanam, E. } \\
& \text { Blochon. } 2.22,362-300
\end{aligned}
$$

(24) Jornasazor, T.;

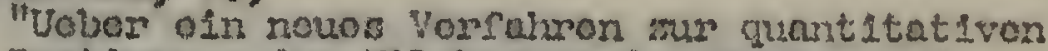

Dosts rmang der Halohesuro in orgaron und

t1orlachen plussicleoton."

$$
\text { Hochem. 2. 10, 361-5030 (1003) }
$$

(25) von ruartis, 0.5

"Merosont igung."

310chara. 2: 24, 010-217 (1020)

(27) von Inorth, 0. and lonucho1n, J.;

"Guaxt 1 tat I vo Bontirmane Uor is Ichsauro nobon botamoxybuttorsaure."

Blochom. 7. 스, 21-104

(1010)

(20) von Inorth, 0 , and Iahlinara, $\mathrm{H}$,

"Uobor dfo qunntitativo Bostirmux dor Mllehauro In ITarno."

$$
\text { BLachon. }: 50,100-682 \text { (1913) }
$$

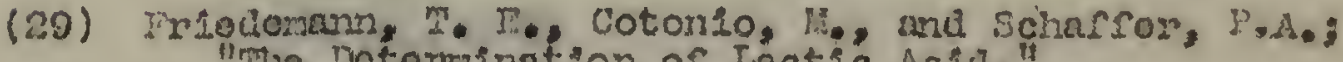
"rio Dotormination of Lactic Acid." J. B101. Chom. 73., 355-358 (1927) 
(30) Ir.jolozinus, 2. I.

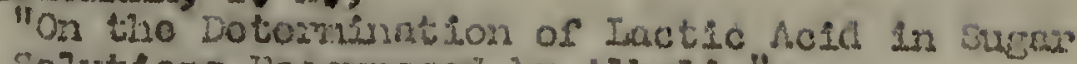

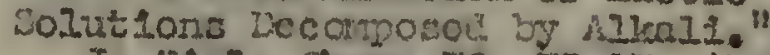
J. 2101. Cicm. 76, 75ma7 (1928)

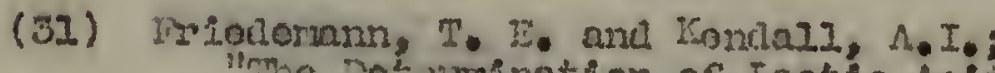

"Mho Dotumination of Iactic Acila,"

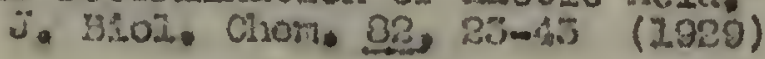

(38) Friodornars, T.2., and Grecsor, J.3.: "ho Dotomination of Lact 10 Acld." J. 3101. Chers, 100, 281-303 (1033)

(33) Mohs, $\pi_{0}$;

"An Apraiatue for Lactic Acie Dotcrulnations."

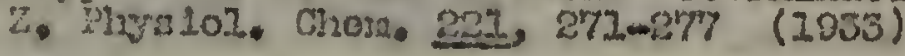

(34) Isob, It, and Racharl, $K_{0} K_{*}$;

"A Simplifrad Apparatur for tho Dotominetion of Lactic Acia.

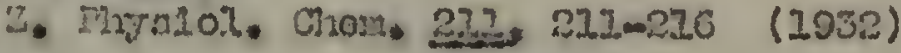

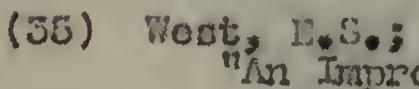

"N⿴囗 Irmprovod Laceso Acie Apparatus." J. 3201. Chom. $30,403-485$ (1931)

(30) huozioz-parchura, $1 ;$

"Iactin Acld Detom Inetion in BIood." 2. IMyc10 . Chor. 210, 200-217 (1032)

(37) Bor7ot, $A$;

"A Irow Luthol of Dotomining-Inctic scia." Conits. rond. roc. b101. 7t, 000-002 C. . . . 25. 253 (1915)

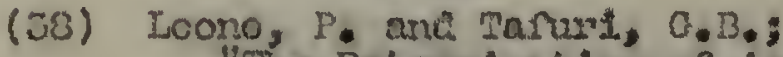

"Who Dotomination of Acotalrolndo in tho (uantitativo Dotormination of Iactic Acla." Avr. Cisin. upnIicata 13, 208-208 (1925) C. A. 18, 2703

(39) Bacon, R... and Durbers, S.B.;

"Dotominat1cn of Inctic hesc and Citrio Acldo

in "Torato Producto." Dus. Msori. Drilotin 78 (1012)

(40) Onodorn, I:

\footnotetext{
"Isolaticn of Lormic, sent1c and Lactio Acids." Bor. Ohare Inst. Iandw. Forsch. 1017, $231-205$ C. A. 15, 2075
} 
(11) Smarborerys $\mathrm{P} \cdot \mathrm{i}$

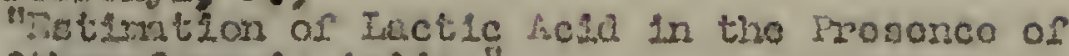
Othoy Oyrearic Aciess.

$$
\text { 5. ann. dilon: 5ig, 505-500 (1917) }
$$

(42) Andercon $A$.

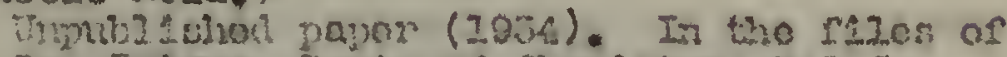

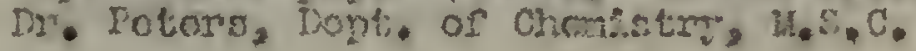

(43) cohnp 12,0

"ine botartintion of Inctic Acic by axthetion."

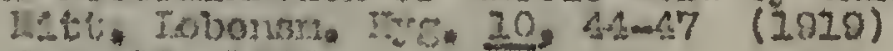

C. . . 15, 2.990

(4L) Sorichor, Lu and Innury, if.;

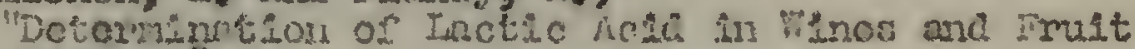
Juscos"

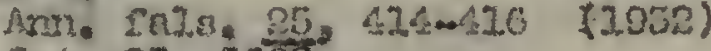

$$
\begin{aligned}
& \text { C. . . 26, } 5038
\end{aligned}
$$

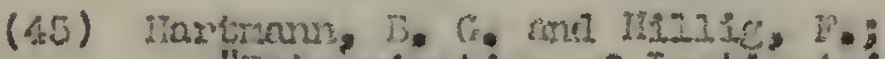

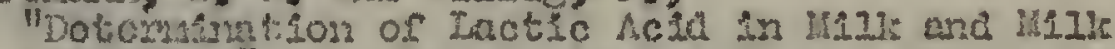

זyolucts.

$$
\text { J. } .0 .0 . C, 20,4005 \text { (2933) }
$$

(46) Avory, i3..., and latitings, A. D.:

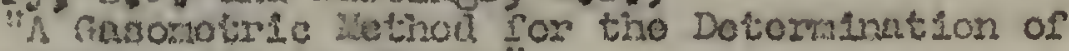

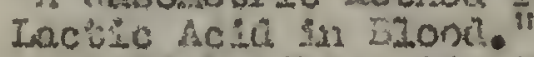
T.R103. Ciser. 26. $273-280$ (1931)

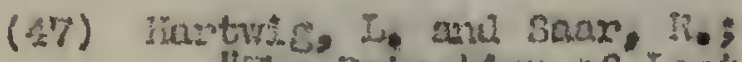

"rito Dotoctian or Lacile Ac?ü.

$$
\begin{aligned}
& \text { Chon. zte. 45, 522 (2022) } \\
& \text { C. A. } 15,20.20
\end{aligned}
$$

(48) Toxiron, $n_{0} \pi_{*}$

$$
\begin{aligned}
& \text { "Mmiophoso rast for Lactio Aclu" } \\
& \text { J. Pixys 102. 35, } 803 \text { (2907) } \\
& \text { C.A. } 13,1800
\end{aligned}
$$

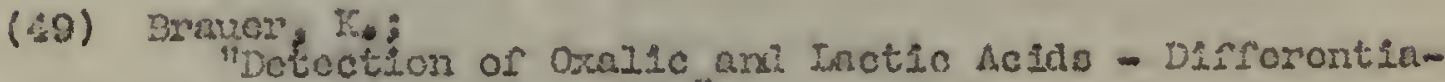
tions from Tartaric."

$$
\begin{aligned}
& \text { Giora. Zue the } 104 \text { (1020) } \\
& \text { C.A. IS, } 27 \%
\end{aligned}
$$

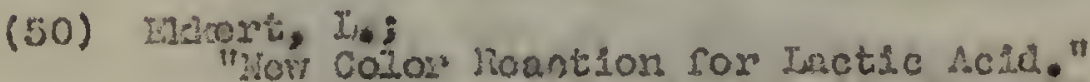

$$
\text { C.A. 20, } 101
$$


(52) Contuth, . a.:

"yotnet?or of Lactic Aebd in the r roconco of

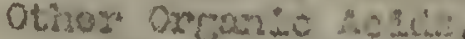
Inh. Ins. Chan. 10, 352-050 (1927)

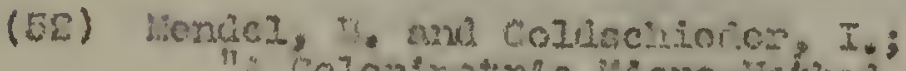

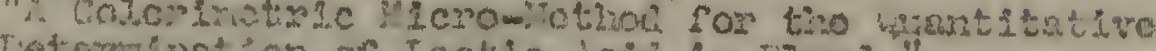

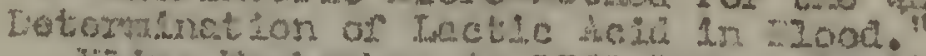

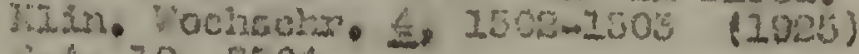
$\therefore 1.29,5501$

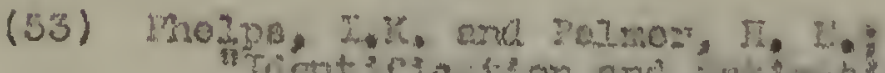

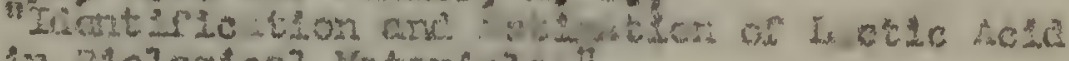

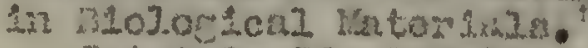
$\pi, A, C, 2.20,150,120(2017)$

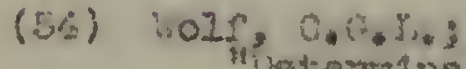

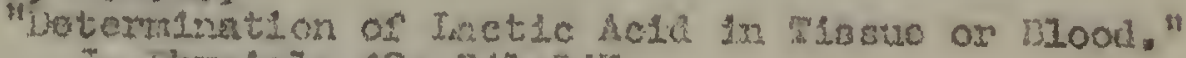

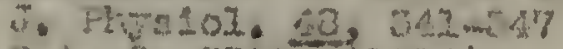

B.A. $1,350<-(1014)$

(55) borjuan, c.r.;

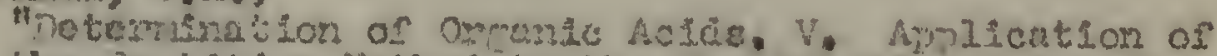
the furtition letral to the hatitativo Detornina-

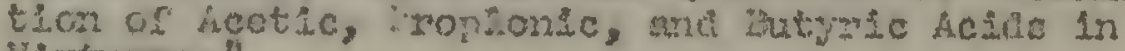
uxtaros."

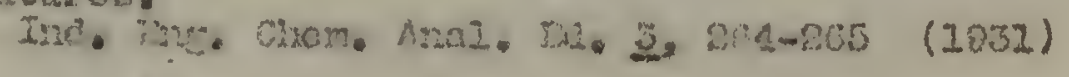

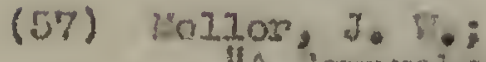

"A Comproincns:vo Trentses on Inomeanic and

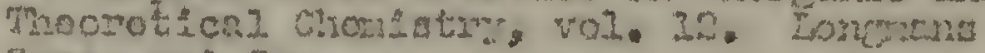

Greon anx. Co. Lorrion (1935) 5ne 606

(58) minog, $5 \mathrm{mLl}$

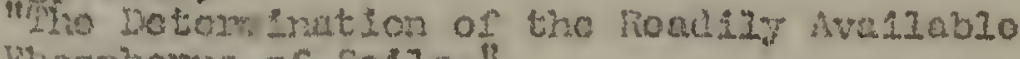

Mrosnliomir of Sol1n."

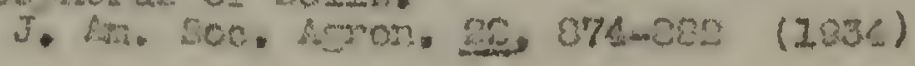

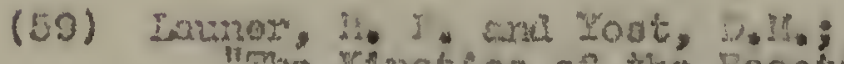

"The Knotice of the Roection betweon Potasstura

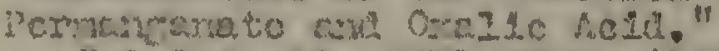

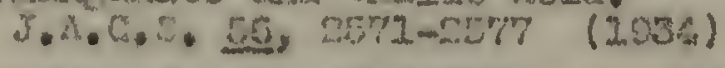

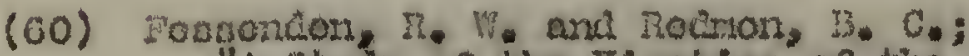

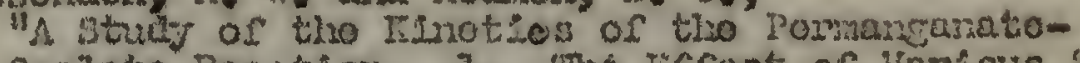

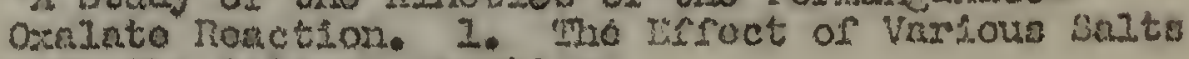
upon tixo Prato of Roaction.

$$
\text { J. A. C. . . 57, 3240-49 (1035) }
$$

(61) Rourton, B, C..

"S Etudy of tiso Xinetice of the I'onnanenatoOxalato Reactior. Unpublishod Fart of $\%$.D. Thesia - Dopartwent of Chomistry, H. E. C. 
(62) Huggins, It. I. ;

"Iydrogen Bridges in Organic Compounds."
J. Organic Chem. 1, $407-456$ (1936). 


\section{ACM OWTISDAEXEIIS}

Tho aution wishos to thasl: the Dopartmont of Chemiatry and the varioun nethers of tho stafe wiro have holped raiso posstulo the cormlation of this thosis.

To Doctor Charios A. Potorg aro thanits carociolly cuo foz muscosting tho probler and for his constant advico and disrection of the problox.

Thanizs aro also duo to Doctor R. W. Fotseriton and to Doctor B. O. Rournon for many holprul succestione concoming

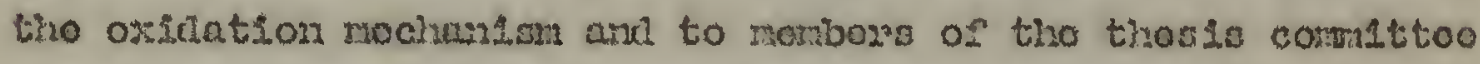

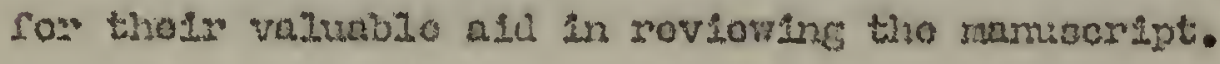


Approtea Uะ:

Ciepetes'
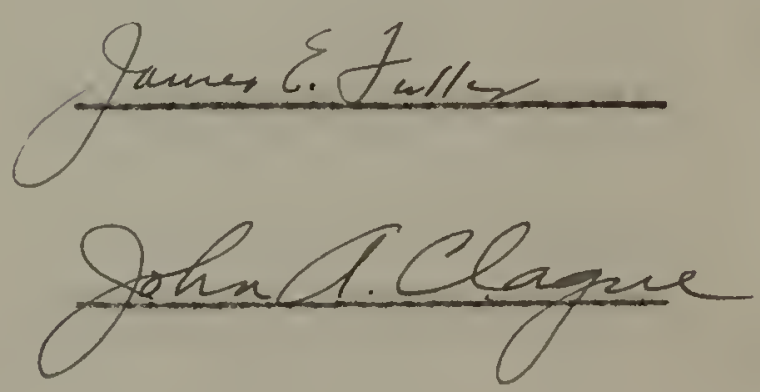

Date:

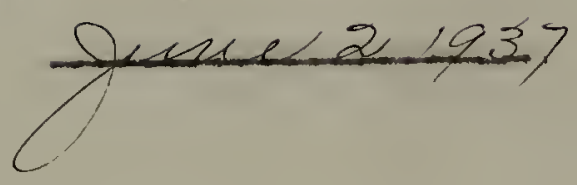




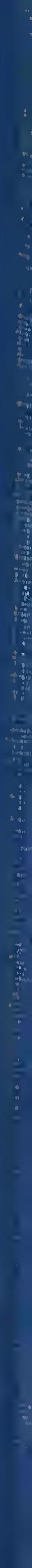

